\title{
Kirsti Lauritsalo
}

\section{"Usually I like school PE, but..."}

School physical education described in Internet discussion forums

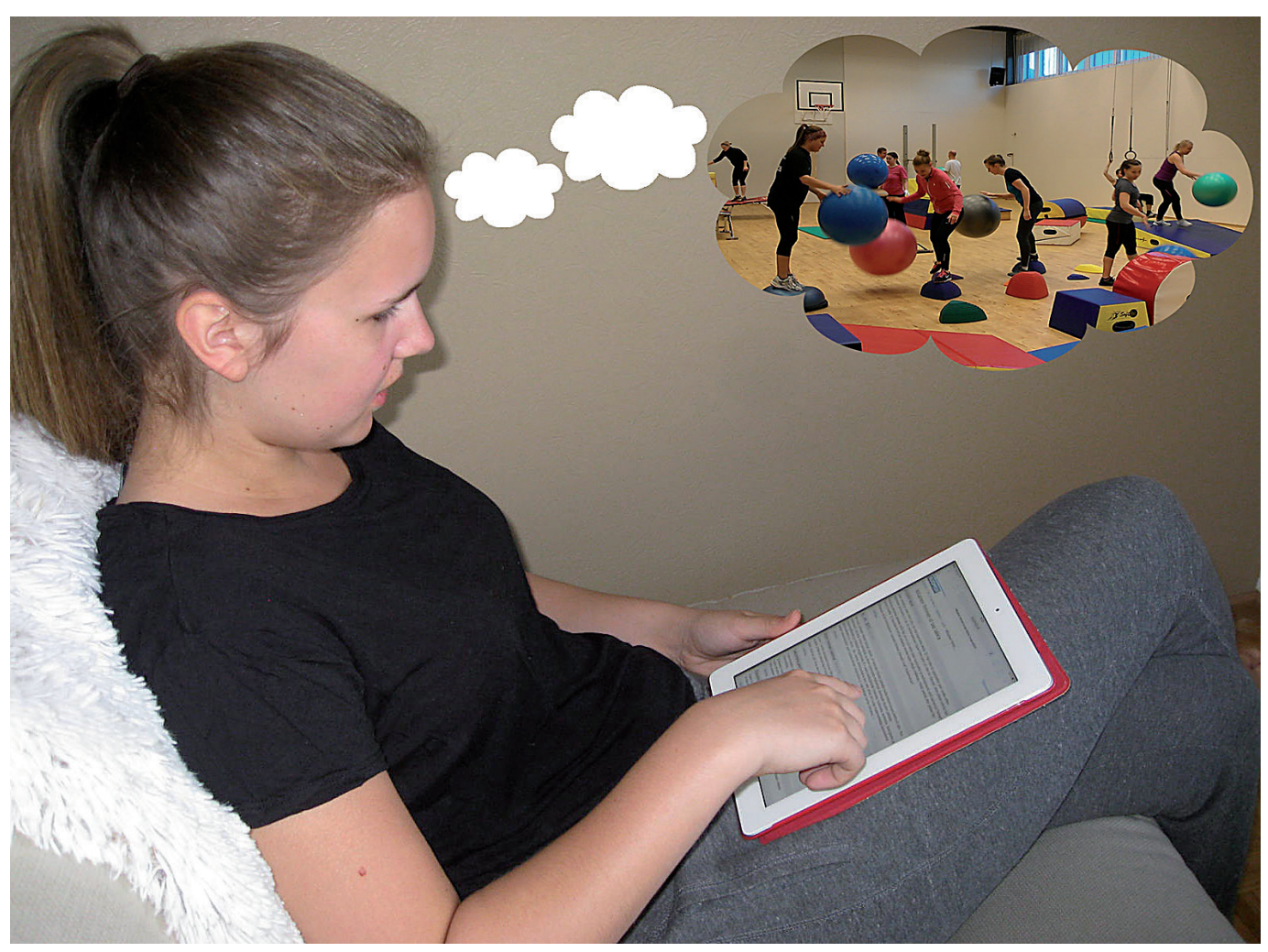




\section{Kirsti Lauritsalo}

\section{"Usually I like school PE, but..."}

\section{School physical education described in Internet discussion forums}

Esitetään Jyväskylän yliopiston liikuntatieteellisen tiedekunnan suostumuksella julkisesti tarkastettavaksi yliopiston vanhassa juhlasalissa S212,

kesäkuun 14. päivänä 2014 kello 12.

Academic dissertation to be publicly discussed, by permission of the Faculty of Sport and Health Sciences of the University of Jyväskylä, in building Seminarium, auditorium S212, on June 14, 2014 at 12 clock noon.

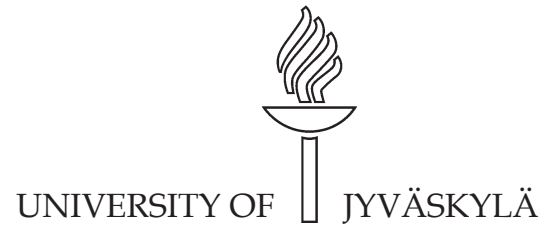

JYVÄSKYLÄ 2014 


\section{"Usually I like school PE, but..."}

School physical education described in Internet discussion forums 


\section{Kirsti Lauritsalo}

\section{"Usually I like school PE, but..."}

School physical education described in Internet discussion forums

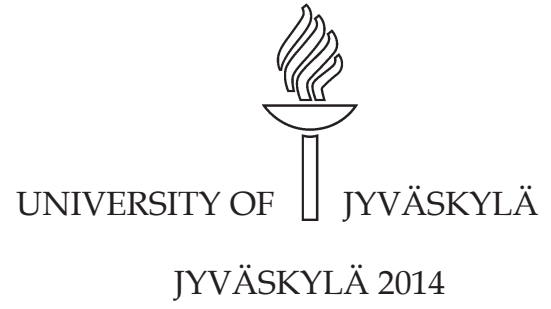




\section{Editors}

Jarmo Liukkonen

The Department of Sport Sciences: Physical Education and Social Sciences of Sport,

University of Jyväskylä

Pekka Olsbo, Timo Hautala

Publishing Unit, University Library of Jyväskylä

URN:ISBN: 978-951-39-5726-1

ISBN 978-951-39-5726-1 (PDF)

ISBN 978-951-39-5725-4 (nid.)

ISSN 0356-1070

Copyright (C) 2014, by University of Jyväskylä

Jyväskylä University Printing House, Jyväskylä 2014 
While we try to teach our children all about life, our children teach us what life is all about.

-Angela Schwindt-

In gratitude, this thesis is dedicated to our dear children, Eric and Michelle! 


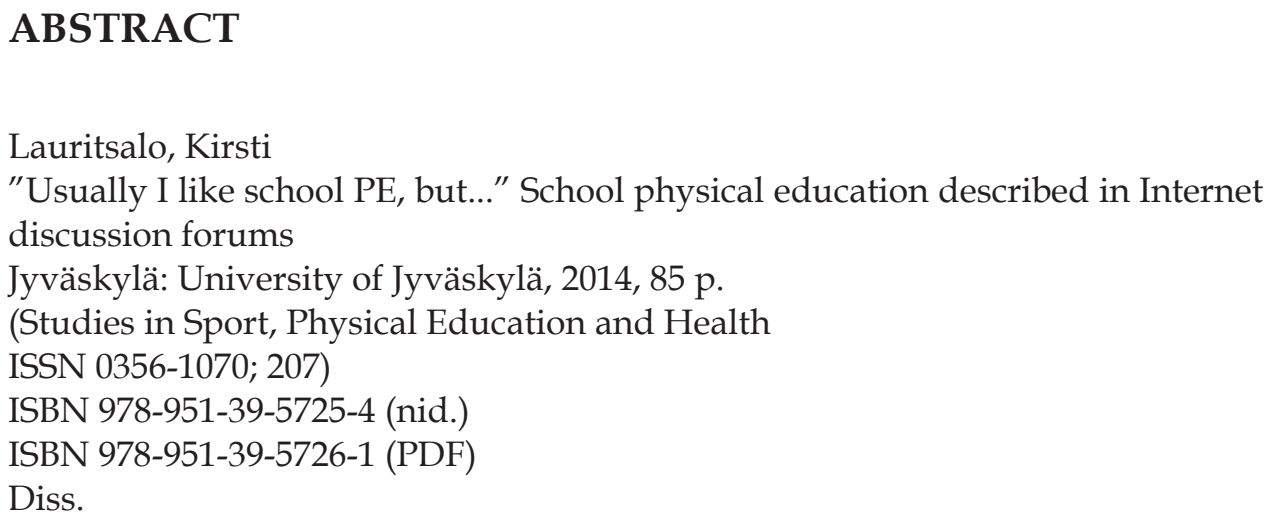

The aim of this study was to enrich the existing picture of school physical education (PE) by investigating messages on the topic of school PE posted on Internet discussion forums, that is, by listening to people's voices online. The study addressed three main research questions: (1) How is school PE described in Internet discussion forums? (2) What factors underlie the various opinions on school PE in Finnish schools expressed in Internet discussion forums? (3) What factors, mentioned in the messages, seem to lead towards engagement in or alienation from school PE?

The data collected for this study comprised two data sets, for which the collection protocol was identical. Data I were collected from Internet discussion forums during a randomly chosen week - number 15 - in April 2007, data II similarly in 2012. The data were collected using a Google ${ }^{\mathrm{TM}}$ search engine with the broad term "koululiikunta" ["school PE" in Finnish] and the first 200 hits were taken for consideration. The data were analyzed using qualitative content analysis and Carlson's (1995) model was applied to the data classification.

The main finding was that the messages posted on the Internet discussion forums studied here referred to negative experiences more frequently, and sometimes with more vehement expressions of dislike of school PE, than has been previously reported in PE studies. The discussion forum messages mainly concerned extrinsic factors, in particular teachers, curriculum and the class environment. Emotions linked to school PE were most often mentioned among the intrinsic factors in the messages.

The findings indicate that students' voices should be more closely listened to by teachers and teacher educators. They need to be more aware of the feelings that PE arouses in order to develop school PE and learning environments that all students can enjoy and which will encourage the adoption of a physically active lifestyle.

Keywords: school physical education, Internet discussion forums, messages 
Author's address

Supervisors

Reviewers

Opponent
Kirsti Lauritsalo

Department of Teacher Education

University of Jyväskylä, Finland

P.O. Box 35

FI-40014 University of Jyväskylä, Finland

kirsti.lauritsalo@jyu.fi

Senior researcher, Docent Arja Sääkslahti

Department of Sport Sciences

University of Jyväskylä, Finland

Professor Helena Rasku-Puttonen

Department of Teacher Education

University of Jyväskylä, Finland

Associate Professor Ben Dyson

School of Curriculum and Pedagogy

University of Auckland, New Zealand

Professor Billy Strean

The Faculty of Physical Education and Recreation

University of Alberta, Canada

Docent Jan-Erik Romar

The Faculty of Education

Åbo Akademi University, Finland 


\section{ACKNOWLEDGEMENTS}

How often and how many kilometers did I walk alone during the early mornings along the lakesides composing these words in my mind? And now, finally, it is time to put it all down on paper. The years spent on this research process have demanded much hard work and been challenging, but also, at the same time rewarding: a real journey to the beginnings of an understanding of science and research, but also of knowledge of self and the people around me. I certainly have no regrets! Despite the many hours I spent working by myself at the university, completion of this doctoral dissertation would not have been possible without the support of several people and communities. I would like to express my sincere gratitude to all of them; here, it is only possible to mention a few by name.

First and foremost, I am extremely grateful to you, my dear supervisors, senior researcher, Docent Arja Sääkslahti and Professor Helena RaskuPuttonen, for the valuable guidance, patience and consistent encouragement I received throughout this whole process: you were always there when I needed you. I have had the best supervisors I could ever have imagined - it has been a real honor to work with you. And I will never forget the moments we shared together around the coffee table before getting down work. I thank you from the bottom of my heart for your invaluable support in both my academic and personal life.

I would like to express my deepest appreciation to Associate Professor Ben Dyson and Professor Billy Strean for pre-examining this manuscript. Your professional and encouraging comments and suggestions helped me put the final touches to this work. Honored Custos, Professor Pilvikki HeikinaroJohansson, thank you for your help and encouragement with the finalizing this dissertation. I would also like to thank all the unknown reviewers of the article manuscripts. The feedback received was certainly helpful at that moment, but also has value for future work. And to all the anonymous writers in the Internet discussion forums: without your posted messages we would not have been able to hear your voices and learn what is going on in your minds.

I have been lucky to be surrounded by wonderful colleagues and friends, who have helped, guided and encouraged me during these years. Thank you! The 'café' in Opinkivi basement yielded many important ideas: my thanks to all those of you who have shared the hours there with me over so many years. I would especially like to thank my friend Ulla for supporting me during the early years of my research career. With you, Juha, moving to Viveca brought us even closer. Thank you for always being ready to help and support me, not only with research but also in everyday work. Thanks also to you, Pira, for abetting and encouraging me. And Leena, we went through the different, sometimes difficult steps of this doctoral process together: thank you for walking beside me.

Without the guidance and persistent help from you, Michael Freeman, it would not have been possible to read this dissertation and all the versions of all 
the article manuscripts in fluent English. Huge thanks for all that work. I would also like to express my warm thanks to Paula Sajavaara for helping me with my Finnish language, and to Esa Nykänen for sharing his knowhow on putting tables and the figures into shape. Thank you also for the layout of my research posters during these years. Being placed second in The Best Poster Award at the 2008 AIESEP World Congress in Sapporo, Japan, at the beginning of this process gave me encouragement and confidence that data collected in this way were internationally acceptable and that the information contained in it was of value.

During some of these doctoral research years, I was fortunate in share in the financial support from the Ministry of Education and Culture awarded for our research project "Vaikuttavuutta koululiikuntaan" [Making school PE more effective]. I am also grateful for the financial support and other help that I received during this process from the Teacher Education Department and its Head of Department Tiina Silander, and the Department of Sport Sciences and its contemporary Head of Department Pauli Rintala.

I am grateful to all my supportive and loving friends: without you I would not have survived in my life. I owe a lot to my parents, who have encouraged and helped me at every stage of my personal and academic life, and longed to see this achievement come true. My dear Mother, among so many other things that I admire in you, you have always been my idol of an interactive, constructionist and visionary teacher, an eternal learner. My dear Father, your unconditional love and admiration has borne me up all the way, and never abandoned me. A Chinese Proverb says, "When the root is planted deep, there is no reason to fear the wind." Thank you both for planting this deep root! Dear Seppo and Pirkko, what would I be if I hadn't been brought up between the two of you? Thank you for your countless support during all my life. To the whole family in Belgium, thank you for all your support in so many ways during these years.

Eric, Michelle and Dirk, my everything! You have been the best teacher in my life, Eric. With you I have learned to open my eyes to see how diverse this life can be, and what is important in it - and also in school PE! Michelle, your endless patience in listening to me at every single step of this work was incredible. You have also taught me a lot about the Internet - and school PE. Thank you, my efficient research assistant! My dearly beloved husband Dirk, these words sum it all up: thank you for your love!

Jyväskylä 14.5.2014

Kirsti Lauritsalo 


\section{LIST OF ORIGINAL PUBLICATIONS}

This thesis is based on the following papers, referred to in the text by the Roman numerals I-IV:

I Lauritsalo, K., Sääkslahti, A. \& Rasku-Puttonen, H. 2012. Student's voice online: Experiences of PE in Finnish schools. Advances in Physical Education 2 (3), 126-131. DOI: 10.4236/ape.2012.23022

II Lauritsalo, K., Sääkslahti, A. \& Rasku-Puttonen, H. 2013. School PE through Internet discussion forums. Physical Education and Sport Pedagogy (online publication /in press).

DOI:10.1080/17408989.2013.788144

III Lauritsalo, K., Sääkslahti, A. \& Rasku-Puttonen, H. 2012. Internetin keskustelupalstalla kirjoitetaan koululiikunnasta: "Ja kaikki näkee, kun sä yrität" [Writings in Internet discussion forums about school PE: "And everybody sees when you're trying"]. KASVATUS 43 (3), 255-267.

IV Lauritsalo, K., Sääkslahti, A. \& Rasku-Puttonen, H. 2013. “PE at our school has been relatively varied recently, but...": Factors of engagement in or alienation from school PE (submitted). 


\section{FIGURES}

FIGURE 1 Developmental mechanisms influencing the physical activity trajectories of children (Stodden, Goodway, Langendorfer,

Roberton, Rudisill, Garcia \& Garcia 2008, 294)

FIGURE 2 Student-centered ecological model adapted from

Bronfenbrenner (1989)

FIGURE 3 Alienation-nonalienation model in the physical education setting

(Carlson 1995, 473) ............................................................................. 26

FIGURE 4 The data analytical process: data I / 2007 .............................................. 41

FIGURE 5 The data analytical process: data II / 2012............................................ 41

\section{TABLES}

TABLE 1 The final ten categories of intrinsic and the extrinsic factors (modified from Carlson's model 1995) 38

TABLE 2 Overview of the specific research questions, the research questions of each sub-study, the data, and the analysis applied in each sub-study 


\title{
CONTENTS
}

\author{
ABSTRACT \\ ACKNOWLEDGEMENTS \\ LIST OF PUBLICATION \\ FIGURES AND TABLES \\ CONTENTS
}

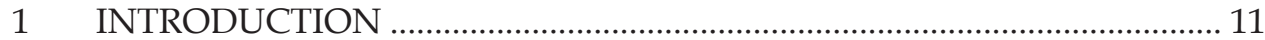

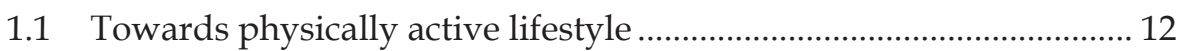

1.2 Student and school physical education in a broader context.............. 14

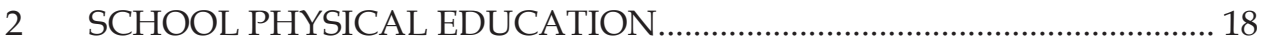

2.1 PE curriculum and the nature of Finnish school PE........................... 20

2.2 Teacher education for PE in Finland..................................................... 22

2.3 Previous studies on school PE experiences........................................... 24

3 INTERNET DISCUSSION FORUMS AS A SOURCE OF MESSAGES....... 29

4 RESEARCH TASK AND RESEARCH QUESTIONS ….................................... 32

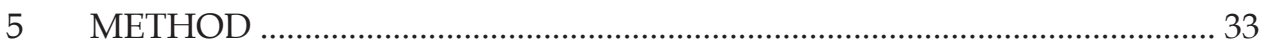

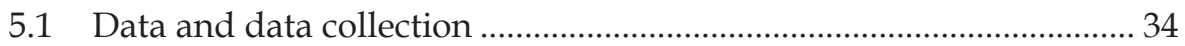

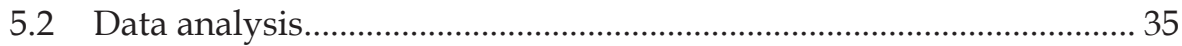

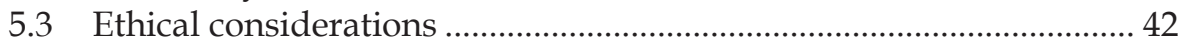

6 FINDINGS ACCORDING TO THE RESEARCH QUESTIONS .................. 46

6.1 School PE experiences in Internet discussion forums (I, IV) .............. 46

6.2 Factors underlying the opinions expressed in Internet discussion

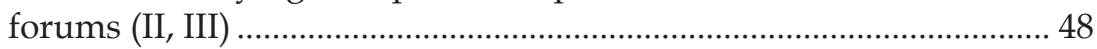

6.3 Factors, mentioned in the messages, that seemed to lead writers towards engagement in or alienation from PE (IV) ........................... 51

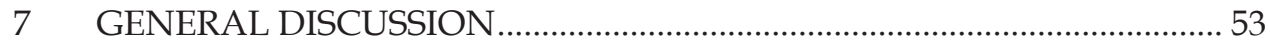

7.1 Main findings and theoretical implications .......................................... 53

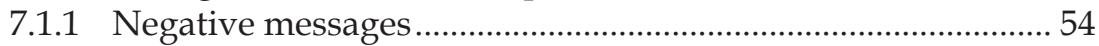

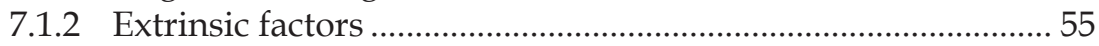

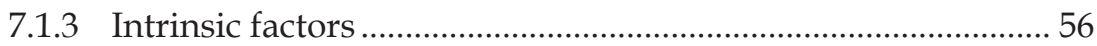

7.1.4 Findings in relation to the model of Bronfenbrenner .............. 57

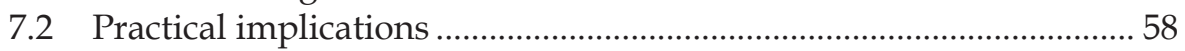

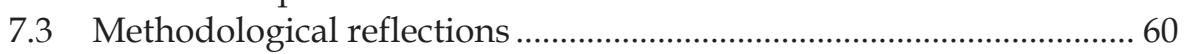

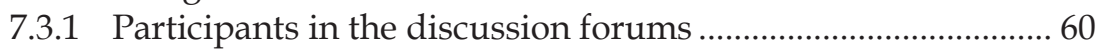

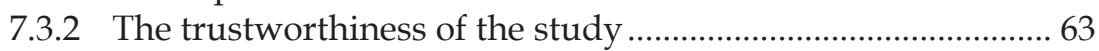

7.4 Conclusions and challenges for future research ................................... 65 


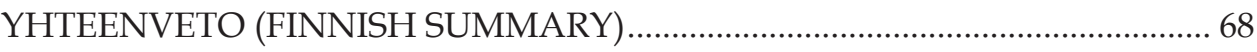

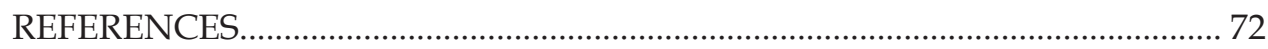

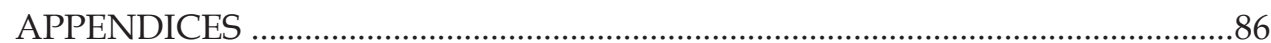




\section{INTRODUCTION}

I can still remember a PE class that Mimmi [my daughter] was in. Eve Luukkonen and I had instructed the student teacher as best we could and we were pretty satisfied with the result. I observed the lesson and gave good feedback afterwards. In the evening Mimmi and I went to sauna and talked about the day. I tried to get Mimmi to tell me how she felt about the PE lesson. But, according to her, there was "nothing special to tell". At that moment, and so often since I've thought that no matter how much we teacher educators, school teachers and students try, will we ever be able to answer the important question, what is "the point" for the pupil? As a mother what I hear most from Mimmi about PE lessons is whom I was allowed or not allowed to work with, and how successful our team was. What about the PE itself? (14.09.2007)

This was a citation from my personal research diary, a memory from the starting point of this project. The same questions continue to revolve in my mind: how is it possible that the same situation can be seen and experienced so differently by the different persons involved? Could - and should - these different experiences resemble each other more? In order to achieve such convergence, it is important to examine what students feel they get from school physical education (PE).

This study aimed to achieve a broader understanding and knowledge of how school PE is described in Internet discussion forums. What are those "points" that matter? It is widely agreed that school PE is a popular subject among school students and that the Internet is a part of everyday life in the world today. The purpose of this study was to gain an insight into the factors affecting school PE as described by posts on Internet discussion forums, and also, based on these public discussions, the factors that seemed to lead the writers towards possible engagement in or alienation from school PE. The research was carried out in the context of school PE in Finland and the orientation to the study is that of $\mathrm{PE}$ and sport science.

The aim of school PE is to create lifelong engagement in physical activity (European Commission/EACEA/Eurydice 2013; Finnish National Core Curriculum for Basic Education 2004; NASPE 2004). A physically active lifestyle is commonly associated with beneficial changes in human development and seen as important for psychological well-being throughout the life course. 
Already from birth, human beings are naturally physically active. In light of Piaget's theory of cognitive development, possession of the fundamental motor skills (balance, locomotor and manipulative skills) are seen as essential for a child's ability to cope in everyday life (Gallahue, Ozmun \& Goodway 2012). Once a child has learned to crawl and stand he/she starts exploring the immediate environment, and by learning and discovering more of the environment, the need to proceed further pushes the child to engage in ever more challenging tasks. The development of dynamic balance enables a child to move, climb, walk, run and jump (Gallahue \& Cleland-Donnelly 2007, 52). The understanding of spatial awareness and one's own body in relation to time and physical forces allows the development of independent movement and the acquisition of more advanced motor skills like throwing, catching, kicking and hitting (Gallahue, Ozmun \& Goodway 2012). Repeated physical activity lays the foundation for achieving the more advanced movement skills that are needed for participation in different sports and also to engagement in a physically active lifestyle (Stodden, Goodway, Langendorfer, Roberton, Rudisill, Garcia \& Garcia 2008). In addition, these early movement experiences also create a basis for the physical self (Fox 1997), which is meaningful for learning and enjoyment in future physical activities.

A physically active lifestyle has many benefits for all (e.g. Bailey 2006; WHO 2009). However, while these benefits are largely known and agreed with, a tension continues to exist between engagement in and withdrawal, or even alienation, from a physically active lifestyle. For some people, various kinds of physical activities, games and other sports are a part of their everyday routine, yet at the same time the number of people who are physically inactive is growing at an alarming rate (Ham, Kruger \& Tudor-Locke 2009). This inactivity is unfortunately also visible in the school context, despite the known benefits of physical activity for educational attainment (e.g. Kantomaa 2010).

\subsection{Towards physically active lifestyle}

PE in to broad sense touches nearly all of us during our lifetime (Coulter \& Chróinín 2011). The school environment and school PE play a notable role in whether or not a person adopts a physically active lifestyle, since it has the advantage of reaching the whole age group (McKenzie \& Lounsbery 2009). Experiences of school PE situations affect future attitudes and life decisions (Fox 1998), meaning that schools have a major role in physical activity promotion. School PE, when delivered appropriately, can lead to enjoyment in future physical activities and to a physically active lifestyle over the lifespan (Bailey 2006; Bevans, Fitzpatrick, Sanchez \& Forrest 2010).

Organized and unorganized sports also play an important role in physical activity outside school PE among children and adolescents. The meaning and role of this leisure time physical activity and its future trends have been widely discussed (e.g. Laakso, Telama, Nupponen, Rimpelä \& Pere 2008). According to 
the current guidelines, young people should engage in 60 or more minutes of moderate- to vigorous-intensity physical activity per day (ACSM 2008; AHA 2007; Strong, Malina, Blimkie, Daniels, Dishman, Gutin, Hergenroeder, Must, Nixon, Pivarnik, Rowland, Trost \& Trudeau 2005). The challenge of achieving this activity level is a global one, since many young people fail to meet these recommendations (Physical Activity Guidelines Advisory Committee 2008; Tammelin, Ekelund, Remes \& Nayha 2007). To minimize inactivity, the recommendations also set a limit on TV- watching and screen time. Screen time should be limited to two hours a day (Tremblay, LeBlanc, Kho, Saunders, Larouche, Colley, Goldfield \& Connor Gorber 2011), although students, at least in Finland, exceed this by a considerable amount (Tammelin, Laine \& Turpeinen 2013).

With the aging of the population, physical activity has become an even more important topic as it concerns everyone. Adopting a physically active lifestyle already in one's earlier years may increase the probability of enjoying more years of both physical and cognitive health and may also protect from possible diseases later in life (Rantanen 2013a; Rovio 2008). A physically active lifestyle has been shown to promote better physical functioning and vitality in work ability (van den Berg, Elders, de Zwart \& Burdorf 2009; von Bonsdorff \& Rantanen 2011). It can also be seen as a counterbalance to work, as it can increase the number of leisure time activities that also involve social functioning and relationships (Biddle \& Mutrie 2007, 137-160). Physical activity can also support well-being and promote health enhancing behavior (Hassmén, Koivula \& Uutela 2000), and may result in better health-related quality of life (van Oostrom, Smit, Wendel-Vos, Visser, Verschuren \& Picavet 2012). For aging people, a physically active lifestyle helps them to maintain functional independence, health and good quality of life (Rantanen 2013b).

David Stodden and his colleagues (2008) created a heuristic model (Figure 1) to represent the importance of the role of motor skill competence in engagement in a physically active lifestyle (see also Clark 2007; Lubans, Morgan, Cliff, Barnett \& Okely 2010). They suggested that children demonstrate various levels of motor skill competence primarily because of differences in their experience of physical activity. As they develop and grow older, children attain increasingly higher levels of motor skill competence, culminating in a large motor repertoire that enables engagement in a wide variety of different physical activities, sports, and games (Clark 2007). At the same time, children's perceived motor competence starts to play an increasingly important role. A child whose perceived and actual motor competence are both low could be drawn into a negative spiral of disengagement, possibly resulting in inactivity and obesity. Health-related fitness is another mediating variable that strengthens in the course of child's development. A positive spiral of engagement, in turn, is characterized by high motor skill competence, higher perceptions of motor skill competence, greater physical activity, and higher levels of health-related physical fitness. (Stodden, Goodway, Langendorfer, Roberton, Rudisill, Garcia \& Garcia 2008.) 


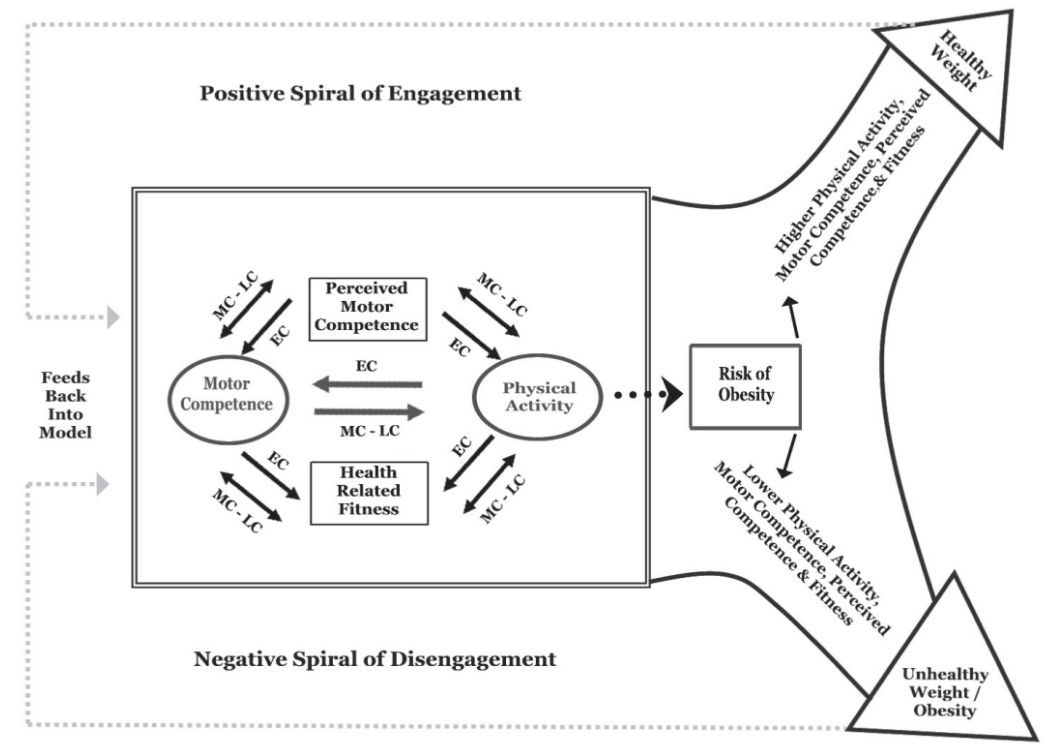

FIGURE 1 Developmental mechanisms influencing the physical activity trajectories of children (Stodden, Goodway, Langendorfer, Roberton, Rudisill, Garcia \& Garcia 2008, 294) (EC= early childhood, MC=middle childhood, LC= late childhood)

Stodden et al. (2008) developed the model for children and connected it closely to health and well-being. Their research focus was on the risk for obesity and its causes, including overweight, and the development of a positive or negative spiral of engagement or disengagement. This is an important topic, given the world-wide concern over the increase in sedentary lifestyles, and specially the patterns of overweight that are prevalent in all age groups (WHO 2009). In addition to this, the main idea in Figure 1 can be seen in a broader context, for example from the point of view of school PE. Physical activity and motor competence are the goals that school PE seeks to enhance, via positive experiences, so as to promote students' healthy development and growth. A student's perceived motor competence is related to his/her physical activity (Mays Woods, Bolton, Graber \& Crull 2007) and having a positive attitude towards school PE (Sollerhed, Ejlertsson \& Apitzsch 2005).

\subsection{Student and school physical education in a broader context}

School PE does not exist in isolation any more than a student is separated from the rest of society. Similarly, the school is part of the larger ecological environment. All this can be inferred from Bronfenbrenner's ecological model (1979). The basic idea of Bronfenbrenner's model was to organize the contexts 
of human development into nested environmental systems (individual, micro-, meso-, exo-, macro - and chronosystem), where the influence within and between the systems was bidirectional (Bronfenbrenner 1979, 1989, 1994).

In this study, the adapted model (Figure 2) presents the development of the student's relationship with PE and a physically active lifestyle. At the center is the student (individual) with his/her physical self, body, self-esteem, perceived motor competence and experiences. Now that the Internet has become so common in everyday life, it is located in the student's immediate relations (microsystem) next to other meaningful relations, including family, friends, peers and teachers (with their lesson plans), that affect the student. The surrounding environment (mesosystem) is comprised of the home, neighborhood, school (with the local curriculum) and other institutions, and leisure time, all of which influence the individual's development in different ways. Society (exosystem) comprises the school system, including the PE curriculum, leisure time activities (like sport clubs), and youth culture with its growing pressure on the individual to engage in social media, both of which have a considerable impact on the student. The outermost layer of this model comprises cultural values (macrosystem), including general laws and rules, school regulations and the national core curriculum, dominant traditions, beliefs and ideologies, and the media, all of which influence the development of the student. The subsequently added layer encompassing (chronosystem) these systems can be understood as people, and the history they carry with them, living in Finland during the years 2007-2012, who belong to the generation with a Western lifestyle, and who could perhaps be called digi-natives or members of the net generation.

Everything that influences the student's relationship with a physically active lifestyle derives from the layers surrounding him/her. Some influences come from the cultural values of society via the media and the school system and curriculum. In the immediate relations layer, teachers play a crucial role as messengers with their values, beliefs and aims in practical learning situations. Some of these general laws and regulations the student draws directly from the media, while others come via the student's relationships with family and friends. As the model shows, all these systems affect each other; in this study, however, the main focus is on the student him-/herself, peers, teachers and the curriculum in the school context, and on Internet discussion forums which occupy part of individuals' leisure time spent on social media. 


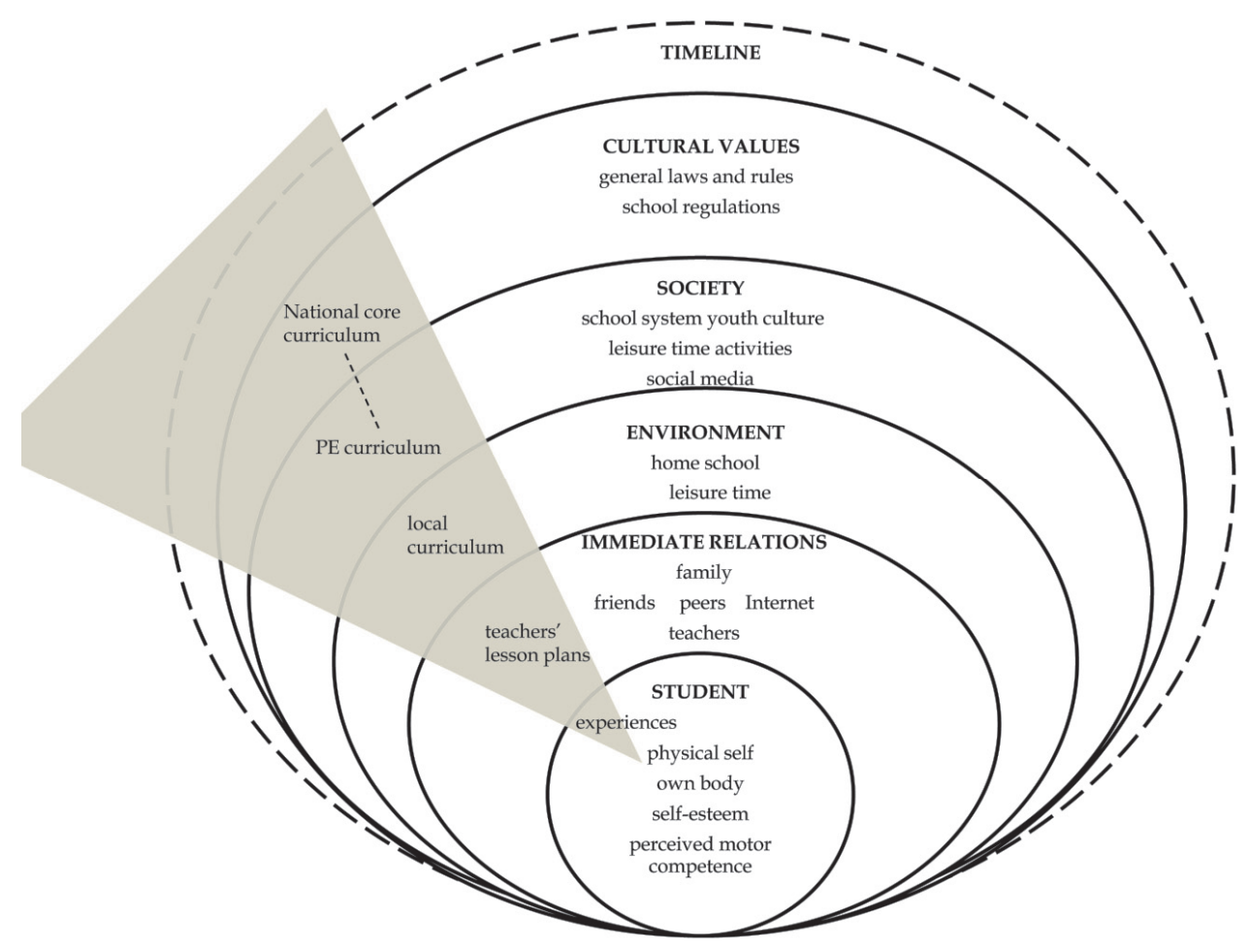

FIGURE 2 Student-centered ecological model adapted from Bronfenbrenner (1989)

A physically active lifestyle, then, is important throughout of the whole life span. The present study focused on the role of school PE in achieving this objective, keeping alive the inborn drive to be physically active. When school PE has succeeded in its main aim of encouraging the student's physical activity and self-esteem (NASPE 2004), the positive feelings and experiences gained thereby can lead towards engagement in PE, while also supporting the broader aim of instilling the confidence needed to enjoy a lifetime of healthful physical activity (NASPE 2004). Positive influences are strengthened by functional cooperation with other students and the teacher (Strean 2009), and also with the surrounding physical culture (Enright \& O'Sullivan 2013; Flory \& McCaughtry 2011).

A large number of studies have been published on school PE, including work on students' attitudes (e.g. Dismore \& Bailey 2010), perceptions (i.a. Trout \& Graber 2009), experiences (see Wrench \& Garrett 2008) and values (e.g. Cothran 2010) regarding PE. Qualitative (e.g. Strean 2009) and quantitative (i.a. Yli-Piipari 2011) research and research with mixed methods, including surveys and questionnaires (e.g. Subramaniam \& Silverman 2007), interviews (see Rikard \& Banville 2006), and observations (e.g. Berg 2010) have all been done. Most studies have reported that students like PE (e.g. Carlson 1995; Dyson 2006; 
Rikard \& Banville 2006; Subramaniam \& Silverman 2007), although a reduction in physical activity and negative experiences have also been found (e.g. Carlson 1995; Morgan \& Hansen 2008; Olafson 2002; Trout \& Graber 2009; Williams \& Bedward 2001).

Thus, there is the contradiction that while PE is a popular school subject, when it fails to achieve its goals, it can be highly unpopular. This provokes the question: What are the reasons for these negative outcomes? Has there been enough research on this issue? What other way might there be to examine the subject? Thus far, relatively few studies have addressed views expressed in Internet discussion forums on the topic of school PE. The aim of this study was to enrich the existing picture of school PE by investigating messages on the topic of school PE posted on Internet discussion forums, that is, by listening to students' (or ex-students') voices online. This approach was further deemed suitable since the messages in the forums existed irrespective of research purposes, and thus not influenced by the researcher or research methods used. 


\section{SCHOOL PHYSICAL EDUCATION}

PE is a widely employed term. Yet, despite its use worldwide, there is no international consensus on what PE means (see also Coulter \& Chróinín 2011). Kirk, Macdonald and O'Sullivan $(2006, x)$ use the term PE as "a means of identifying the key process of being educated in, about and through movement as a medium." PE is very commonly linked to school. By prefixing the word "school", a more precise definition can be constructed. The characteristic needs of different countries and societies, each with its own curriculum, bring different aspects to bear on the topic, but also the challenge of defining it. While school PE can be understood in many ways, the commonest understanding is twofold (e.g. Jaakkola, Liukkonen \& Sääkslahti 2013, 22-23). First of all, school $\mathrm{PE}$ is understood as PE lessons organized and given according to the school curriculum, "koululiikunta" in Finnish. On this understanding, school PE has clearly defined goals and it is taught a specific number of hours weekly. The second, larger view of school PE, assumes that it is more than just a subject (Coulter \& Chróinín 2011). It also includes extracurricular physical activities outside the regular PE teaching hours, "koulun liikunta" in Finnish. It includes, for example, the breaks between lessons, the integration of PE with various other school subjects, trips to and away from school, after-school activities, special days or events, and competitions (Asanti 2013, 620-636; European Commission/EACEA/Eurydice 2013).

School PE, as a school subject, has the advantage that it develops the whole person, despite the emphasis on physical activity (European Commission/EACEA/Eurydice 2013). School PE is implemented mainly in groups with different people, but also partly independently. School PE classes offer great opportunities for practicing and learning the social and interactive skills needed in life (Lintunen \& Kuusela 2007). The student's responsibility for his/her own and the group's actions and behavior is constantly present. Following the rules, winning and losing, and coping with one's feelings are present at all times in PE classes, although in Finland without an emphasis on competitiveness (European Commission/EACEA/Eurydice 2013). PE is different from the other school subjects, as in PE the tool used is the student's 
body, and consequently learning and 'doing' are visible to everyone (Olafson 2002). Assessment, too, often feels as if it is targeted at the body itself. These, among others, are the reasons why situations in PE classes need handling with special pedagogical care (Ferry, McCaughtry \& Hodges Kulinna 2011). Teachers have to know, 'who' their specific students are as individuals, groups, and as a whole, and accept them for who they are (Ferry, McCaughtry \& Hodges Kulinna 2011).

School PE is important because it reaches the whole age group. School PE also guarantees, or should guarantee, equality between the students irrespective of their background or the wealth of their family (Basic Education Act 1998). Not all children have the possibility or resources to participate in different hobbies and sport clubs during their leisure time, but within the framework of school PE they can experience a large range of sports, games and other physical activities. When school PE is delivered according to the curricular goals, it can ensure that all children have a possibility to engage in physical activity. For this reason, school PE has the potential to promote leisuretime physical activity, reducing overweight and sedentariness, and supporting overall learning abilities (NASPE 2004). To extend the possibilities for success in this objective without giving up the other aims, different curricular models, such as the Sport Education Model (Siedentop 1994), Teaching Games for Understanding, TGFU, (Bunker \& Thorpe 1982), Creating and Developing Games, CDG, (Quay \& Peters 2008), and, recently, Health Optimizing Physical Education, HOPE (Metzler, McKenzie, Van der Mars, Barrett-Williams \& Ellis 2013) have been created. In Finland, Finnish Schools on the Move ("Liikkuva koulu" in Finnish), is a national action program aiming at establishing a physically active culture in Finnish comprehensive schools in general, and not only during school PE lessons (Liikkuva koulu 2014). Nevertheless, in Finland the current school PE curriculum sets guidelines for teachers on the values, principles, aims and goals, contexts, teaching methods, evaluation, and educational support to be implemented in school PE lessons (Finnish national core curriculum for basic education 2004; Finnish National Board of Education 2013; Heikinaro-Johansson 1995; Pietilä \& Koivula 2013).

Linguistically, the Finnish compound word "koululiikunta" [school physical education] is challenging to translate. The first word is easy since "koulu" means "school". However, the second word "liikunta" is much more difficult to define (see also Laakso et al. 2008). It translates into English both as "physical education", and also as "exercise". It can also be understood as physical activity, - whether inside or outside school, - or as training or sport. Debate has also centered on the English words "physical education" and "sport" (Bailey 2006). In this study "koululiikunta" is a school subject delivered in curriculum-based lessons by a qualified teacher. The translation used here is school physical education (school PE). In addition to the term "koululiikunta", the Finnish word "liikuntalaji", which translates as "sport" is multidimensional in the school PE context (Ferry \& McCaughtry 2013). In the school PE context in Finland, and also in this study, sport is used as an umbrella term for all the 
sports, games and other physical activities a school offers as part of PE, e.g. athletics, orienteering, different ball games, swimming, gymnastics, fitness, dance, and different winter sports.

\subsection{PE curriculum and the nature of Finnish school PE}

The aims of school PE in Finland are set down in the Finnish National Core Curriculum for Basic Education of 2004 and the National Core Curriculum for Upper Secondary Schools, which was reformed in 2003. In addition, the Finnish National Board of Education is responsible for the development of pre-primary, vocational upper secondary and adult education. In this study, the main focus is on school PE in basic education, since that is the level that influences almost every student during his/her school years. The aims and goals of school PE in the curriculum can be structured according their level and range (Gallahue \& Cleland-Donnelly 2007, 10). Here, the broad, overall targets are called aims, for example a physically active lifestyle. More specific targets, or goals, include motor and interactive skills, and, on the most practical level, are objectives, such as the skills needed in specific sports.

The overall mission of basic education in Finland is to "provide an opportunity for diversified growth, learning, and the development of a healthy sense of self-esteem" (Finnish National Core Curriculum for Basic Education 2004, 12). The aims in the updated core curriculum for 2016 onwards are "defining educational values and principles so that they are based on supporting the versatile growth of pupils, strengthening their identities and utilizing interactive methods that promote sustainable development" (The Finnish National Board of Education 2013). These aims can be implemented in different subjects or integrated within seven different cross-curricular themes (Finnish National Core Curriculum for Basic Education 2004). The first of these overlapping themes is the student's growth as a person, where the main focus is on learning to understand the physical, personal and social development of the individual student. Understanding a student's uniqueness as an individual and learning to function as a member of a group are the specific goals within this theme (Finnish National Core Curriculum for Basic Education 2004). The other six cross-curricular themes are cultural identity and internationalism; media skills and communication; participatory citizenship and entrepreneurship; responsibility for the environment, well-being, and a sustainable future; safety and traffic; and technology and the individual (Finnish National Core Curriculum for Basic Education 2004). School PE has its own role in all of these via PE's special character and possibilities.

The PE curriculum in Finland includes the basic values of the whole public school system, how learning is understood, the aims, methods and more specific goals and contexts of teaching content, unlike in many Englishspeaking countries, where teaching is organized according to other curricula models, including those mentioned earlier, such as the Sport Education Model, 
TGFU, CDG, and HOPE (Lyyra 2013). Health has always been a basic value in Finnish school PE over the years, with a focus nowadays on well-being (Heikinaro-Johansson \& Telama 2005). Health-optimizing PE is also a major focus internationally, the aim being to keep students active and improve their health (Sallis, McKenzie, Beets, Beighle, Erwin \& Lee 2012). The other values seek to guarantee students' physical, motor, psychological and social development (Finnish National Core Curriculum for Basic Education 2004).

According to the Core Curriculum for Basic Education (2004), the aim of school PE is to build the pupil's self-esteem and positive physical self-concept through favorable school PE experiences and to encourage cooperativeness and positive future sport and health behavior. These aims are in line with the international aims of PE (European Commission/EACEA/ Eurydice 2013; NASPE 2004). The aims of the Finnish curriculum are related to cooperation, health, motor skills and knowledge associated with lifelong engagement in physical activity (Finnish National Core Curriculum for Basic Education 2004). Socialization and team work are also highlighted more in the Finnish curriculum than in most of the curricula in the other Western countries, where more emphasis is laid on competitions and results in school PE (Annerstedt 2008).

In Finland, compulsory education starts in the year a child reaches his/her seventh birthday (Sahlberg 2007). PE is a school subject across all the school years. During the early education years, qualified class teachers (also called primary school teachers or generalist teachers) teach the whole class as one group. This means that girls and boys start school PE in primary school together, but in most cases from the third grade (8-9 years old) onwards they continue separately, which is typical in Finland but less common in many other countries (Pühse \& Gerber 2005). At this point, girls usually have a female and boys a male teacher. During the first six grades, students (7-12 years) are mainly taught by a class teacher and for the next three years they are taught by a qualified PE subject teacher (also called a specialist teacher) (see also European Commission/EACEA/Eurydice 2013).

During the first four years, school PE lessons are organized through the planning of different games in a supportive environment, proceeding from the fundamental skills towards more specific motor skills. Learning is rooted in students' own activity and their imagination and ideas are utilized. The next five years of PE are more related to students' growth and development. With a versatile PE curriculum, the student's well-being and independence as along with social and interactive skills are supported. Success in this overall task means the students are prepared to for the adoption of lifelong engagement in a physically active lifestyle. The teaching of school PE in the new national curriculum, which will be introduced in 2016, will be strengthened by increasing the average annual number of hours allotted to the subject from 57 to 63 a year (Finnish National Board of Education 2013). This means that every student will have two or three hours of school PE per week, organized in single (45 minutes) or double (90 minutes) lessons. The theoretical maximum amount 
of school PE at two hours per week will 76 hours, and at three hours per week it will be 114 hours, during one school year (Sääkslahti 2012, 9). The various special occasions and celebrations held in schools will reduce these amounts considerably.

In the last three grades of comprehensive school (13-16 years) and in upper secondary school (high school, 16-19 years) students may choose to take optional courses in PE (Finnish National Core Curriculum for Basic Education 2004). Finnish students do not wear a school uniform, either in general or in school PE classes. PE is evaluated in course or term reports verbally or numerically on a scale of $4-10$, where 10 is the highest grade. The national core curriculum includes descriptions of good performance (grade "good" or 8) for the fourth and eighth grade in all the compulsory subjects, including PE (Finnish National Core Curriculum for Basic Education 2004). This collective and normative guideline is given in order to guarantee that teaching and evaluation are more or less in line across the country.

PE in Finnish schools has a long tradition, and the curriculum is naturally influenced both by the history of the country and by its geographical location. Finland's four-seasons climate gives Finnish PE its special character (see also Annersted 2008). During the autumn, from the middle of August on, outdoor sports are mainly athletics, orienteering, soccer and Finnish baseball. The cold winter forces students inside, where indoor ball-games (e.g., volleyball, basketball), swimming, gymnastics and dance are taught. When the weather allows (at temperatures down to minus $18^{\circ} \mathrm{C}$ and not too strong a wind) classes do cross-country skiing, ice-skating and play ice bandy. In the spring, activities mainly continue inside until it is warm enough to exercise outside, usually from the end of April onwards. Then, again once it is time for athletics, soccer and Finnish baseball (Finnish National Core Curriculum for Basic Education 2004). The school season finishes at the end of May. A typical school PE lesson starts with a game or a short warm-up, continues with the main objective of the lesson and finishes with a game or another applied way of using what has just been taught. After class, the students shower before the next lesson on their timetable.

To sum up, school PE in Finland is based on a national curriculum, which lays down its values, aims, methods and goals. School PE attempts to supply the requirements of physical activity through different curriculum-based physical activities, and, it is hoped, positive school experiences.

\subsection{Teacher education for PE in Finland}

PE teacher education is an important element of the broader aim of making school PE effective and enjoyable. One teacher during a life-long career delivers around 30,000 PE lessons and during them meets about 100,000 students (Armour 2010). Seen thus, it is self-evident that the teacher's role is important. This in turn means that teacher education has the important task of supporting 
the professional development and pedagogical decision-making of PE teachersto-be by influencing their attitudes and thinking in ways that will ensure that school PE is a valuable and positive experience for all.

Teaching is a highly respected, coveted and committed profession in Finland (Sahlberg 2007, 2010; Välijärvi et al. 2007). The target of the university entrance exams is to select the best, most pedagogically orientated and motivated, future teachers from among a huge number of applicants. In 2013, the number of applications nationally for the classroom-teacher program (excepting the Swedish-language unit in Vaasa) rose to 16080 , of whom only 733 candidates were finally admitted (VAKAVA 2014). During the same year, 2013, for the PE subject teacher program, only 61 of the 1897 applicants were selected (University of Jyväskylä 2014). A teacher in Finland has a high degree of autonomy and considerable pedagogical freedom, meaning that there are no school inspections and no official ranking lists (Koski \& Pollari 2011; Sahlberg 2007). Both class teacher and subject teacher studies are Master's degree programs and take approximately five years to complete, and comprise a minimum of 300 ECTS credits (Finnish National Board of Education 2013).

For class teachers, education is the major subject, and it is offered by seven Finnish-language universities and one Swedish-language university. In addition to this major subject language and communication studies, various school subjects, also known as multi-field studies, and pedagogical studies are included in the classroom teachers' Master's degree program (Finnish National Board of Education 2013). The amount of PE in classroom teachers' studies varies between universities from 2-5 ECTS credits within the multi-field component. These few credits are mainly scheduled to be completed within the first three years of studies. If a student wishes to specialize in PE he/she can take around 25 ECTS in most of the universities, and up to 60 ECTS credits in some of them. The university entrance examinations include, in the first phase, a book exam, the VAKAVA [national selection cooperation network in the field of education] test (VAKAVA 2014), which enables prospective students to apply for education as a class teacher. If they pass this test, applicants have an additional written test and an interview. In the interview, interactive skills and social competence, having a realistic picture of the profession, self-confidence and motivation are emphasized. Approximately, 770 students annually start the program (Nissinen \& Välijärvi 2011).

For PE subject teachers, teacher education in Finland is unique because it is all centralized at the University of Jyväskylä. It is also highly valued by the applicants, as it is the second most sought after study place in the University (Kalaja, T. 2012). In this program, the major subject is PE pedagogics. In addition, the degree is made up of various sports, language and communication studies, and the Master's thesis (University of Jyväskylä 2014). The entrance examination for the PE teacher program comprises three phases: a theoretical test, a short (five minutes) micro teaching session and sports tests to evaluate various motor skills. The emphasis is on good motor skills, good sport pedagogical and biological knowledge, and good pedagogical skills as shown in 
the short micro teaching session. It should be noted that the student applies directly for the teacher education program (Mäkelä \& Huhtiniemi 2011). Annually 700-800 applicants sit the entrance tests, but only 5-6\% can be offered a place (Kalaja, T. 2012).

Both of these teacher education programs include completed supervised teaching practice as part of their studies, starting already in the first year and continuing until the final year, enabling students to develop their pedagogical skills in a systematic way. This teacher training is mainly organized in the Teacher Training School. The Finnish Teacher Training School system seems to be quite unique when compared with systems elsewhere (see Kontoniemi \& Salo 2011). The schools used for teacher training purposes in Finland are an integral part of their respective universities and operate within the Faculty of Education. The training schools also provide a general education for comprehensive and upper secondary pupils. At the University of Jyväskylä, the buildings housing the two teacher training schools are located close to the university, and thus it is easy for the students combine their studies with their periods of teaching practice. In the teacher training school, PE teaching intertwines theory with practice (Mäkelä \& Huhtiniemi 2011), meaning that the schools' PE teachers supervise the trainees in co-operation with the university PE lecturers during the teaching practice periods.

\subsection{Previous studies on school PE experiences}

Today's sedentary lifestyle has been accompanied by global concern about the resultant increase in overweight (e.g. McKenzie 2007; WHO 2013) and the fact that inactivity/sedentary behavior is the fourth leading risk factor for early mortality (Pratt et al. 2012; WHO 2013). These results have recently led researchers in the school PE context also to emphasize issues of health and physical activity (Hartmann, Zahner, Pühse, Schneider, Puder \& Kriemler 2009; Lee 2010), including in Finland (Kalaja, S. 2012; Kauravaara 2013; Yli-Piipari 2011). At the same time, in sociological research in the sport sciences awareness of one's body is becoming increasingly important in education settings (Enright \& O'Sullivan 2013; Evans, Davies \& Rich 2009, 401; Oliver 2010), again including in Finland (Berg 2010; Nurmi 2012; Siljamäki 2013).

Since the stated aim of school PE is to encourage lifelong engagement in physical activity (European Commission/EACEA/ Eurydice 2013; Finnish National Core Curriculum for Basic Education 2004; NASPE 2004), a positive attitude towards PE is needed for its achievement. To this end, positive experiences of school PE are essential (Fox 1998; Johansson, HeikinaroJohansson \& Palomäki 2011; Kirk 2005). To be able to offer experiences that are as positive as possible and at the same time minimalize negative ones, teachers need to understand what lies behind a student's thinking and the reasons for his/her behavior (Carlson 1995; Fox 1998). According to Whitehead and Corbin (1997), PE is a double-edged sword: appropriately used it can boost physical 
self-esteem, but inappropriately used it can have negative effects. They continue by suggesting guidelines for enhancing positive physical self-image and promoting involvement in active life: what should be done (e.g. emphasize task mastery, promote self-determination, and promote intrinsic fun and excitement) and not done (e.g. overemphasize peer comparison and competition, make support contingent on performance) in PE.

The experiences a student accumulates during his/her PE lessons form the basis of the general picture he/she acquires about school PE (Kirk 2005). How $\mathrm{PE}$ is experienced at school is important for the future sport and health behavior of the student him/herself (Carroll \& Loumidis 2001; Fox 1998; Trudeau \& Shephard 2005; Yli-Piipari 2011) and for his/her physical self-esteem (Fox 1998, 2000; Biddle, Wang, Chatzisarantis \& Spray 2003). Therefore, today's schools and the prevailing PE culture are under strong pressure to generate positive student experiences.

It has been found in a number of studies conducted with questionnaires, observations and interviews that many students report PE as their favorite subject (e.g. Carlson 1995; Coulter \& Woods 2011; Dyson 2006; Rikard \& Banville 2006; Subramaniam \& Silverman 2007; Zhu 2013). According to this substantial body of earlier research, most students - around 75\% - enjoy PE at school. In Finland, the findings, mainly obtained through questionnaires on experiences of school PE have also been more or less positive, varying between $68-78 \%$ of respondents (e.g. Nupponen, Penttinen, Pehkonen, Kalari \& Palosaari 2010; Palomäki \& Heikinaro-Johansson 2011; Penttinen 2003; YliPiipari, 2011).

In a recent Finnish dissertation on the pedagogy of being heard, Louhela (2012) identified interaction and relationship quality as the core factors supporting students in school PE. Klemola (2009) examined how PE teacher education could increase future teachers' knowhow about social and emotional interaction, as didactic decisions by teachers are not enough - they also need to learn socio emotional skills (Armour 2010; Bailey, Armour, Kirk, Jess, Pickup, Sandford and the BERA 2009; Kuusela 2005). Teachers should also pay attention to the social and emotional knowledge of their students (Ferry, McCaughtry and Hodges Kulinna 2011). As a result, when talking about good and positive experiences in school PE, the most often mentioned are fun (Garn \& Cothran 2006; Phillips 2011; Rikard \& Banville 2006; Zhu 2013) success (Portman 2003) and joy (Blankeship \& Ayers 2010; Kretchmar 2008). A positive and safe class environment (Armour 2010; Liukkonen, Barkoukis, Watt \& Jaakkola 2010) being together with friends (Dismore \& Bailey 2010; Portman 2003; Strean 2009), and the importance of the teacher (Cothran \& Kulinna 2007; Haerens, Aelterman, Van den Berghe, De Meyer, Soenens \& Vansteenkiste, 2013) are also commonly reported, as also is a wide range of physical activities in the curriculum (Rikard \& Banville 2006).

As mentioned above, school PE experiences are often described positively. Some students, however, report negative experiences of PE (e.g. Carlson 1995; Morgan \& Hansen 2008; Rikard \& Banville 2006; Trout \& Graber 2009; Williams 
\& Bedward 2001), including in Finland (Berg 2010; Kosonen 1998; Louhela 2012; Yli-Piipari, Jaakkola \& Liukkonen 2009; Zacheus \& Järvinen 2007). Educators continue to wrestle with the challenge of providing all students with school PE programs that do not lead to negative feelings and experiences (Gibbons \& Humbert 2008). Despite such efforts, some students have feelings of discomfort that can lead them to disengagement, and even alienation, from school PE (Carlson 1995; Halas 2002; Spencer-Cavaliere \& Rintoul 2012).

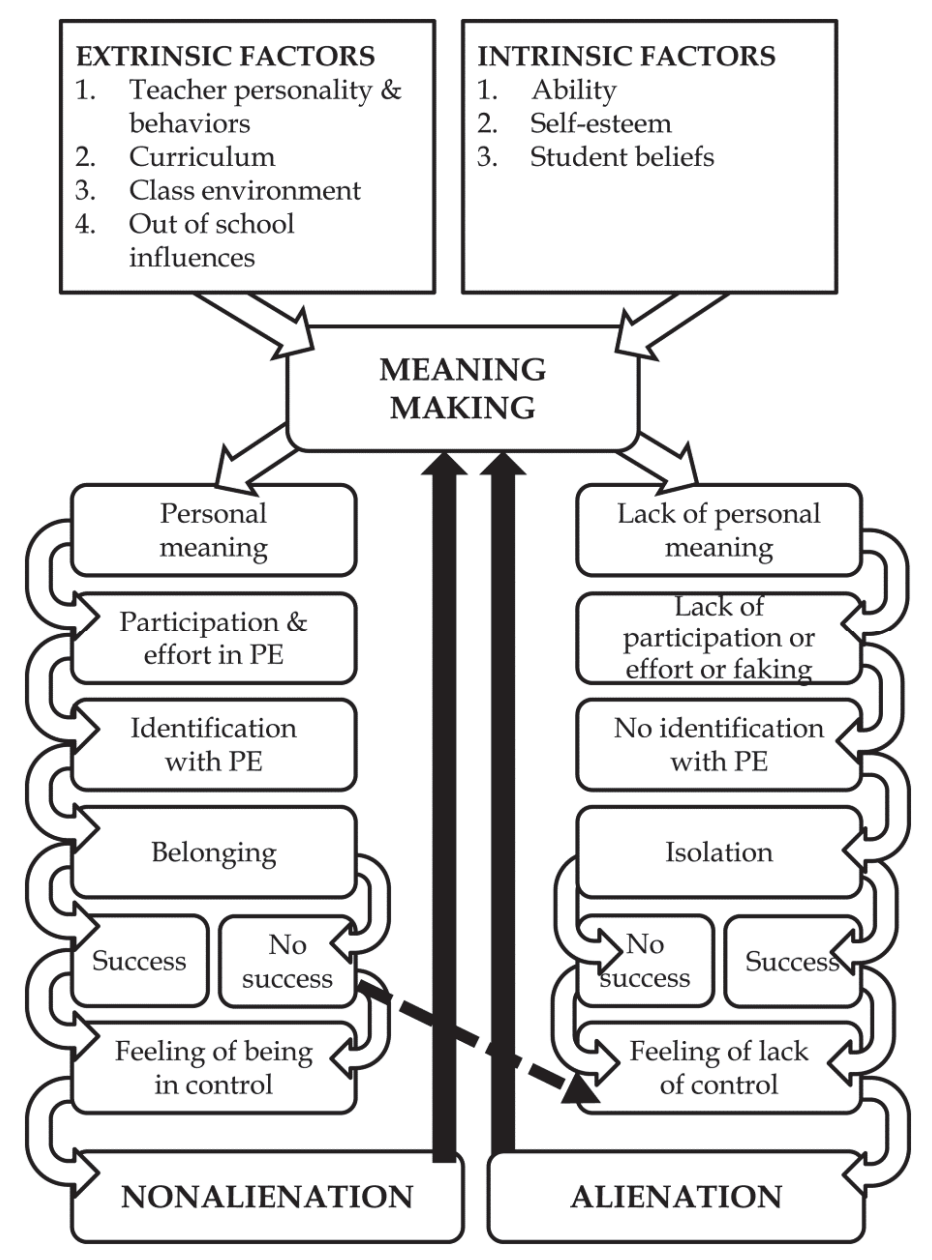

FIGURE 3 Alienation-nonalienation model in the physical education setting (Carlson $1995,473)$

With respect to alienation from PE, Carlson (1995) published her well-known alienation-nonalienation model (Figure 3) in connection with her study "We hate gym". In her model, Carlson (1995) divides the factors that were known to have an impact on students' feelings towards PE and affect student's meaning making in school PE into two groups: intrinsic (student's ability, self-esteem and student's beliefs) and extrinsic (teacher personality and behavior, 
curriculum, class environment, and outside school influences) factors (Carlson 1995). The meaning that PE classes have for a student leads him/her to choose one of two paths: the path towards nonalienation or the path towards alienation (see Figure 3).

Carlson (1995) defined three constructs which lead towards alienation from PE. The first was meaninglessness, referring to lack of personal meaning or value in PE. The second was powerlessness, understood as lack of control in $\mathrm{PE}$, and the third was social isolation, a feeling of being socially or emotionally isolated from one's peers in PE (Carlson 1995).

The personal value that students attribute to school PE is connected to their perception of the activities in question as repetitious and boring (Couturier, Chepko \& Coughlin 2005; Spencer-Cavaliere \& Rintoul 2012). Such perceptions can be changed if the content and delivery of school PE is approached in an appropriate way (Ennis 2013; Ferry \& McCaughtry 2013). For example, in their study on boys' perceptions of the intersection between masculinity and school PE, Tischler and McCaughtry (2011) recommend that teachers should take time to find out what activities their students like or dislike and, especially, why. A narrow range of activities and repeating the same things year after year gives rise to feelings of boredom (Carlson 1995; Cothran \& Kulinna 2007; Flintoff \& Scraton, 2001; Rikard \& Banville 2006; Spencer-Cavaliere \& Rintoul 2012) which in turn can erode the feeling of fun and enjoyment (Bernstein, Phillips \& Silverman 2011). Phillips (2011) pointed to the importance of having fun in PE classes, and that class activities were important, especially team problem-solving and fitness activities (Phillips 2011). How the curriculum is delivered and the atmosphere of the class environment built up depends greatly on the teachers' pedagogic skills (Bailey 2006; Garn \& Cothran 2006; Halas 2002; Spencer-Cavaliere \& Rintoul 2012). Cooperative learning and student-centered learning methods could be ways of building a safe environment for learning and enhancing the meaning and personal value of PE (Dyson \& Casey 2012). In a study of students' values, Cothran (2010) reminded teachers that, in contrast to their teachers, students value noneducational aspects (mostly those connected with fun), such as passing grades, and spending time and playing with friends. She underlined the importance of the meaning of the values students hold, especially when talking about the curriculum (Cothran 2010).

Low degree or total lack of control refers to a student's perception of his/her own skills and/or the skills of others. Students could be helped to overcome such feelings of powerlessness if they are presented with a range of different activities and the possibility to choose among them (Carlson 1995; Rees, Kavanagh, Harden, Shepherd, Brunton, Oliver \& Oakley 2006; SpencerCavaliere \& Rintoul 2012; Tischler \& McCaughtry 2011). The risk with too splintered a range of different sports is that the student does not have enough time to learn and absorb everything that is taught. From the standpoint of learning different motor skills, there is simply not enough time available (Bernstein, Phillips \& Silverman 2011). And when the same content is repeated 
after an interval, students have often already forgotten what they had previously learned. This does not create a feeling of control (Carlson 1995; Cothran \& Ennis 1997; Spencer-Cavaliere \& Rintoul 2012) and can hinder participation (Bernstein, Phillips \& Silverman 2011).

The feeling of being socially or emotionally isolated from one's peers in the gym is easily linked to the division of students into teams (Berg 2010; Rink 2010). In these situations the role of the other students is important (Dismore \& Bailey 2010; Strean 2009). The fear of being embarrassed and humiliated due to low motor competence or low perceived motor competence can, when the pressure to perform well is strong, lead to withdrawal (Berg 2010; Louhela 2012; Strean 2009). Bullying during school PE lessons, and especially after the lesson in the dressing room, is also critical in the context of feeling socially or emotionally isolated (Morgan \& Hansen 2008; Trout \& Graber 2009). Shen, McCaughtry, Martin, Fahlman and Garn (2012) argue in their study on urban high-school girls' sense of relatedness and engagement in PE that girls who felt related to their teachers and their peers also reported higher emotional and behavioral engagement than those who did not perceive such relatedness.

In researching the relationship between PE bibliographies and the PE teaching practices of classroom teachers, both quantitative and qualitative analyses (Morgan \& Hansen 2008) showed that negative school PE experiences were common, even in PE teachers' memories of their own school days. The main reasons given for unpleasant memories were feeling that one has not been taught, feeling that one has not learned anything, and 'tyrannical' teachers. Some teachers reported negative experiences related to a strong atmosphere of competition, in which the pupils felt uncoordinated and scared. Teachers' personal experiences as learners of sports also affect their subsequent selection of the teaching content from the curriculum (Ferry \& McCaughtry 2013). Zacheus and Järvinen (2007), in a survey of Finns born 1923-1988, found that having a negative attitude to PE was higher among the younger generations. They found three main reasons for negative experiences of PE: excessive competitiveness, such as measuring times and distances among other achievements; teacher insensitivity to dissimilarities between pupils, manifested in such ways as treating them unequally or voicing negative and public criticism; and, third, teachers' abuse of their authority, such as forcing a pupil to participate when the teacher knew that the person was frightened.

To sum up, when talking about negative experiences of school PE, the most often mentioned were the teacher (Haerens ym. 2013; Strean 2009), the lack of variety on offer (Gibbons \& Humbert 2008; Rikard \& Banville 2006), or, when variety was offered, it was boring (Cothran \& Kulinna 2007; SpencerCavaliere \& Rintoul 2012), lack of success (Fisette 2013; Portman 2003), a depressing and negative atmosphere (Azzarito, Solmon \& Harrison 2006; Berg 2010), and evaluation and testing (Wrench \& Garrett 2008). 


\section{INTERNET DISCUSSION FORUMS AS A SOURCE OF MESSAGES}

Many far-reaching changes have happened in society during recent decades, such as the introduction of high-speed digital technology (Pratt et al. 2012) and social media (Lietsala \& Sirkkunen 2008). Although today's life style is very hectic, people seem to spend more time sedentary and also online. These developments challenge the younger generation to consider the place and meaning of physical activity and sport in their daily lives (Kauravaara 2013). Physical activity has become only one form of consumption among many others (Salasuo 2012). Communication through Internet discussion forums (also called Web or online forums, discussion or message boards) can be one way of being sociable and participating nowadays. Typically, such messages are saved permanently, and hence can be accessed a long time after their original posting. Messages can vary in length, from a word or few up to many pages.

In Finland, Internet discussion forums are popular. At the beginning of this research project, in 2007 , about $75 \%$ of people had access to the Internet at home, while the share of Internet users was already almost $100 \%$ among the population under age 40 , with only a small percentage difference between men and women (Statistics Finland 2007). Of the total of Internet users, 29\% used the net for chat or discussion forums (Statistics Finland 2007). By the time of data II collection in 2012, the proportion of Internet users had risen to $90 \%$ among those aged 16-74 years, and $87 \%$ of the population had access to the Internet at home (Statistics Finland 2012).

Internet discussion forums, also known as Web forums, can be seen in many different ways. On the one hand, they can be seen as places where people can express their emotions and participate in discussions on issues of interest to them (Hersberger, Murray \& Rioux 2007). The large scale of Internet discussion forums makes the use of networks easy. When communicating, the individual can feel secure that his/her message can be sent without embarrassment (Yun \& Park 2011), meaning that whatever one writes can be sent anonymously. People writing in Internet discussion forums are active in giving and receiving emotional and informational support (Drentea \& Moren-Cross 2005; Eriksson 
2013; Ransom, La Guardia, Woody \& Boyd 2010; Pitts 2004; Seale, CharterisBlack, MacFarlane \& McPherson 2010). Readers, of course, cannot know if the writers have really experienced the things they write about, or whether they are dramatizations of their experiences or even wholly imaginary, as by their nature discussion forums make it possible for people to express themselves through real or fictitious messages (Markham, 2007). One's personality can be totally hidden behind the screen (Kangasniemi 2008; Markham 1998; NiemiPynttäri 2007; Tapscott, 2009; Yun \& Park 2011). Internet forums are places where the opinions, feelings and experiences of people interested in the same topic can be brought out (Hersberger, Murray \& Rioux 2007). The advantage of working online is that joining in is not dependent on time or place (Drentea \& Moren-Cross 2005). The user of an Internet discussion forum is likely to have joined the forum voluntarily. He/she feels a need to share his/her opinions on a particular topic with others, whether to introduce something new or to comment on, object to or defend views that have already been posted. The writer has every opportunity to tell the truth and describe a real experience, but just as easily the story told may be wholly imagined. Control of the self, and the conditions and presentation of communication is an important advantage of online communication (Markham 1998).

Deep-felt emotions, disappointments and experiences create strong feelings that people want to write about and share with others. It seems to be easier to express these negative feelings online (e.g. Ransom, La Guardia, Woody \& Boyd 2010; Seale, Charteris-Black, MacFarlane \& McPherson 2010). For example, descriptions of the writer's self, feelings, body and experiences of shame reveal the uncertainty that the writer has faced. Accepting oneself is rarely easy. People today face ever stronger demands from the outside world, the meaning and the pressure of which are easily exacerbated by the Internet (Kenway \& Bullen 2001; Rich \& Miah 2009). A message posted in a discussion forum is limited by the writer's verbal ability. A writer may not be able to express him/herself as profoundly as he/she would like to, leading to misunderstandings on the part of readers. In research situations, if the poster of a message has been unable with any precision to describe or verbalize his/her negative feelings, for example in a social situation at school or in class team work, he/she might express such feelings in an Internet forum by simply criticizing the teacher. However, there may also be an unwritten imperative in forums to compete with previous writers and make one's experiences sound worse or better than theirs (Hagger, Wood, Stiff \& Chatzisarantis 2009), i.e. posting provocative or strong messages (Millard 1997; Tepper 1997).

On the other hand, Internet forums have their advantages for researchers. Internet discussion forums are being used nowadays in a number of different ways for research purposes. How a research project is approached, whether, for example, it is approached on the basis of communications technology, culture or linguistics will depend on the target (Arpo 2005). A study can be conducted by means of a survey posted on an Internet discussion forum set up for the purpose (Laukkanen 2007; Markham 2007). Other studies may be conducted by 
following/joining a discussion ethnographically (Kytölä 2013). Data can also be collected that are totally unaffected by the purpose of the research, as in the present study (see also Eriksson 2013). Discussions and opinions that exist in forums independently of research purposes open the door to an inner world where neither the writers nor the messages are there explicitly to furnish data. This provides an opportunity to follow a conversation imperceptibly in its authentic environment. Internet discussion forums have been used for listening to voices online in the context of personal and intimate matters, for example eating disorders (e.g. Ransom, La Guardia, Woody \& Boyd 2010), breast cancer (Pitts 2004), prostate cancer (Broom 2005), girls and Web forums (Grisso \& Weiss 2005), homosexuality (Brown, Maycock \& Burns 2005), motherhood (Drentea \& Moren-Cross 2005), and family relations (Eriksson 2013). In Finland, recent dissertation studies have addressed girls and sexuality (Laukkanen 2007) and multilingual language among football players (Kytölä 2013) in Internet discussion forums.

Listening to students' voices both for teaching and for research purposes is important but at the same time challenging (Cothran \& Kulinna 2007; Dyson 2006; Fisette 2013; Subramaniam \& Silverman 2007). Various new ways of 'listening' to students' voices have been explored (see O'Sullivan \& MacPhail $2010,1)$. To improve teaching and learning, and to create a possibility for open interaction between students and teachers, it is important for students to have alternative ways of expressing their thoughts and feelings. For this purpose, the Internet has opened up new possibilities.

PE aims at producing positive experiences in schools (NASPE 2004). However, it is a subject that strongly divides people's opinions. The aim of the present study was to examine how people describe their experiences of PE in Internet discussion forums. Thus far, there has not been enough research on discussions in Internet forums on the topic of PE. Listening to the writers' voices in their own natural context outside of a formal research setting could contribute to knowledge in the field of school PE. 


\section{RESEARCH TASK AND RESEARCH QUESTIONS}

The aim of this study was to broaden understanding on meaningful factors and experiences during school PE. PE teachers perform valuable and challenging work with sensitive individuals. Today's students may have a different relationship with their bodies than their forbears; if so, this challenges PE teachers to find new ways to encourage students to adopt a physically active lifestyle. A student's personal experience of school PE is important for his or her future sport and health behavior, and, possibly, physically active lifestyle (Carlson 1995; Fox 1998; Stodden et al. 2008). For this reason, schools and the PE culture are under strong pressure to produce increasingly positive student experiences. Nowadays people's voices can be listened to in a new way, through the Internet. Following Internet discussion forums is one way of gaining an idea of what is going on in students' minds. The Roman numeral at the end of each research question refers to the sub-studies reported in the four attached articles. Each of these sub-studies seeks to elaborate the main research task from a different point of view.

The main research task was to investigate what kinds of school PE experiences do people describe in Internet discussion forums.

More specifically, the research questions were:

1. How is school PE described in Internet discussion forums? (I, IV)

2. What factors underlie the various opinions on school PE in Finnish schools expressed in Internet discussion forums? (II, III)

3. What factors, mentioned in the messages, seem to lead towards engagement in or alienation from school PE? (IV) 


\section{METHOD}

This qualitative study was conducted in the field of school PE pedagogy. The data were messages posted on open Internet discussion forums about the writers' experiences of school PE. At the outset of this research project, the messages about school PE in the discussion forums were intended to be analyzed as a pilot study. However, close inspection of these messages showed them to be so interesting, diverse, absorbing and, surprisingly, so numerous that they eventually became the database of this dissertation study.

Qualitative content analysis (Braun \& Clarke 2006; Patton 2002; Tuomi \& Sarajärvi 2009) was chosen as it was well suited to both the research task and the data. According to Patton (2002, 432), a major analytical challenge in qualitative research is in the massive amount of data that needs to be sifted to locate the content of interest. The analysis was grounded in a pedagogical approach, the aim being to discover themes (Braun \& Clarke 2006) on how people write about school PE, or factors that could influence learning and teaching in the context of school PE. Using inductive analysis without trying to fit the data into an already existing coding frame (Braun \& Clarke 2006; Patton $2002,453,463)$, four groups of themes or categories clearly emerged from the data. The core consistencies and meanings I identified as themes (Braun \& Clarke 2006) or patterns (Patton 2002, 453), where pattern refers to a descriptive finding and theme to a category constructed from patterns. The four themes, or categories I labelled positive, both positive and negative, negative, and other. In addition to the qualitative method, components of quantitative research were also used to be able to estimate the prevalence of themes in the data where this was felt to be useful.

In the subsequent analytical process, I found Carlson's (1995) model useful in classifying the data; in other words, the analysis rested in part on a preexisting theoretical framework that had been widely used in the PE context (Carlson 1995). During the process of classification, I also had to enlarge the original model (see Figure 3) with new categories based on the findings from the data. Thus, epistemologically this study adopts a constructionist perspective. 
The main concern in this section is to show how the methodological choices and analyses were driven by the research questions. The timeline and the phases of the analyses are shown in Figures 4 and 5. Next, the treatment of ethical issues throughout the research process is described. At the end of this section, Table 1 gives a compact overview of the specific research questions, the data, and the analysis applied in each sub-study.

\subsection{Data and data collection}

The data I collected for this study comprise two data sets, which I labelled data I and data II, and for which the collection protocol was identical. I collected the first data set in 2007 and the second one in 2012. I collected data II as a supplement to data I after a five-year interval. The idea behind the second data collection was to be able to compare changes in the Internet discussion forum messages across the five years. It is clear that use of social media increased during these years and more posts could be expected. Another reason for the second data collection was that I wanted to make sure that the results offered a broader view than just a one-week snapshot. In total, the data sets contained 1 661 messages (450/data I and 1211 /data II). All these posts existed independently of research purposes in these open and public forums. They are listed in Appendix 1.

I collected data I from Internet discussion forums during a randomly chosen week - number 15 - in April 2007. During the weeks before that date, nothing in particular had happened in Finland to prompt any special reason to motivate discussion of PE. I collected the data using a Google ${ }^{\mathrm{TM}}$ search engine that shows the requested documents according to the number and quality of the links to them. It is the most widely known and used search engine in Finland. Via Google ${ }^{\mathrm{TM}}$ search (and Internet Explorer) with the broad term "koululiikunta" ["school PE" in Finnish], the first 200 hits yielded nine discussion forums (in total 155 pages). The first forum was the $31^{\text {st }}$ hit. The pages before that consisted of, for example, different links to the PE curriculum in municipalities, various symposia and research results. The succeeding forums were found in $35^{\text {th }}, 5^{\text {th }}, 77^{\text {th }}, 90^{\text {th }}, 94^{\text {th }}, 9^{\text {th }}, 13^{\text {rd }}$ and $197^{\text {th }}$ place among these 200 hits. Since I set no criteria (age, race, class, gender or other), these Web forums represented a variety of areas, including discussions on animal rights, junior football, health, overweight and memories of sports in (see Appendix 1). I selected all nine forums, numbered from one to nine, and took each post found on each of the nine sites during this particular week for consideration. The forums contained between 11-150 messages varying in length. In this study, all these messages were taken for consideration in their original form. Altogether the nine discussion forums yielded 450 separate messages, i.e. every post on each of the nine sites that I found during this particular week.

I collected data II from Internet discussion forums during week 15 in April 2012, exactly five years after the first data collection. By collecting the second 
data I wanted to confirm the adequacy and credibility of the data. Also during the weeks before this date, nothing in particular had happened in Finland to prompt any special reason to motivate discussion of PE. I collected the data in the same way as data I, using a Google ${ }^{\mathrm{TM}}$ search engine that shows the requested documents according to the number and quality of their links. Via Google ${ }^{\mathrm{TM}}$ search with the same broad term "koululiikunta" ["school PE" in Finnish] the first 200 hits, on this occasion, yielded 26 discussion forums (in total 547 pages). The first forum was the $3^{\text {rd }}$ hit. The two hits before that consisted of a link to a Finnish sport association and a link to the PE curriculum of a Finnish town. The succeeding forums were all found among these 200 hits, with the last forum, the $26^{\text {th }}$, in $195^{\text {th }}$ place. Since, again, no additional criteria were set, other than the above, these Web forums represented a variety of areas, including discussions on memories of school sports, health, different hobbies and overweight. One discussion forum (about junior football) that I had also included in data I, I nevertheless allowed to remain in data II with all its messages. These 26 forums (see Appendix 1) I selected, numbered from one to 26 and analysed further. The forums contained from 3 to 253 messages varying in length. These discussion forums yielded a total of 1211 separate messages including every post on each of the 26 sites that I found during this particular week in 2012.

\subsection{Data analysis}

I mainly analyzed data sets I and II according to the same protocol during the same year in which I collected them. To give a clearer picture of the analytical process, these two data sets (I and II) are described separately (see Figures 4 and 5). In both cases, the coding and the analysis of the data consisted of three different phases. More detailed quantitative information on each analytical phase are shown in Figures 4 and 5. Trustworthiness is dealt with by applying the concepts proposed by Lincoln and Guba (1985), e.g. trustworthiness, credibility and consistency.

\section{Data I}

Phase 1: Using qualitative content analysis (Patton 2002), familiarizing (Braun \& Clarke 2006) myself with data, reading and re- reading the messages several times, they seemed to fall clearly into four different groups or themes (Braun \& Clarke 2006).

1. If no negative comments about PE were contained in the message, it was labelled "positive". Messages stating an opinion or agreement with a former writer and not containing anything negative were also included in this group. Neutral messages were also assigned to this group. The following is an example of a positive message: 
"I liked school PE, for me it was never a drag! In particular track and field and crosscountry skiing were close to my heart because of my own hobbies. The teachers were pretty much all pleasant and fair-minded." $(7,8,16)^{1}$

2. If the message included a single positive comment while the rest was negative (or vice versa), it was assigned to a group labelled "both". For example:

"Personally, it's not like I hate school PE, but team disciplines in particular really piss me off. Swimming and orienteering, on the other hand, are really great sports. " $(3,13,41)$

3. If the message contained no positive comment it was labelled "negative". For example:

"What I hated about PE was the fact that everybody was always eyeing what you were doing and then having a good laugh if you did something wrong. That was really unpleasant and I didn't like doing PE one little bit." $(5,10,78)$

4. The fourth group consisted of messages with various topics mixed in with the issue of PE. This group was labelled "other". The messages in this group included, for example, messages about eating and being overweight, smoking, the writer's own physical condition and competitive sport interests, and other school subjects. An example of these messages:

"Oh yes, but it is rather unfair for instance giving grades in music. Those who have music as a hobby, in other words those who are musically gifted, easily get a 10. The tonedeaf, those who can't sing or have short fingers won't get a ten for singing, identifying pitch or playing any instrument, and they don't even have the chance to practice at home like for example, a guitar player. Grades shouldn't be given for music, music lessons should just be general education." (3,13,90)

These groups or themes, I initially labeled positive, negative, both positive and negative (later called both for short) and other. After reading the messages in the "other" group more closely, I discarded this group, as it did not directly concern the topic of this research, school PE (Braun \& Clarke 2006; Patton 2002, 466). This left 356 messages in data I. The research unit, or as Braun and Clarke (2006) call it, extract, was one message, as it was posted, in a discussion forum, no matter how short or long it was. To ensure trustworthiness (Lincoln \& Guba 1985), the data were sequentially coded within six months. In case of unclear or ambiguous messages, the research team (me and my supervisors) classified them as a team to guard against too much being read into unclear messages by one individual (Patton 2002, 466). The first sub-study (Article I) aimed to give a general description of the research data as whole. In this summary, this phase one of the analysis answered the first research question linked to data I.

At this point in the research process, the data allowed possibilities for deeper insight. Some of the messages, although only a few, were only one word long, and in other cases, a message might extend to more than one A4 page (printed as a Word file). This was interesting and encouraged the taking of a closer look at these messages, since most usually contained more than one opinion. In this study the term 'experience' is understood to include all the

1 All the writers of the messages referred to in this study were given codes in which the first two digits indicate the discussion forum and the third the running number of the message 
feelings, emotions, affects, images, beliefs, attitudes, memories and opinions the writers revealed in the discussion forums on their experiences of school PE. Henceforth the word 'Opinion' is used as an inclusive term for all of these.

Phase 2: I analyzed the messages in data I in greater depth (Braun \& Clarke 2006; Patton 2002, 452-468). Depending on its length, a single message could contain several sentences, opinions and ideas. For this reason, I divided the messages into smaller segments such as paragraphs, sentences or even words. These segments - extracts or the research units - I termed 'Opinions' (total $\mathrm{n}=652$ ). This meant, for example, that since all the positive messages included only positive statements, they were all classified into positive opinions. Similarly, all the negative messages comprised only negative statements. The group 'Both' was classified into both positive and negative opinions, as the original messages also included both. (Figure 4)

A large number of the opinions had to be structured and coded in some way. In Teresa Carlson's article (1995) "We hate gym", in which she presents her alienation-nonalienation model, she divides the factors she sees as relevant into intrinsic and extrinsic. The intrinsic factors are ability, self-esteem and student beliefs, and the extrinsic factors are teacher personality and behavior, curriculum, the class environment, and out-of-school influences (Carlson 1995). This intrinsic-extrinsic classification already adapted for PE by Carlson, also seemed to be applicable in the present study for grouping the opinions. The rest of the Carlson's model was not applied here. The notion of intrinsic-extrinsic helped in beginning the analysis of the opinion data as many of the factors seemed to be present. Thus, the analysis rested on an already pre-existing theoretical framework (Braun \& Clarke 2006).

Phase 3: I grouped all the 'Positive', 'Both' and 'Negative' 'opinions' in data I into intrinsic and extrinsic factors (Figure 4) on the basis of Carlson's (1995) alienation-nonalienation model. However, I extended the Carlson's (1995) definition of intrinsic and extrinsic. Multiple reading of the messages and the 'opinions' revealed two new intrinsic items, i.e. range of emotions, and sidesteps and explanations, and two new extrinsic items, i.e. assessment, and facilities and equipment. Hence, I identified ten (10) categories: 
TABLE 1 The final ten categories of intrinsic and the extrinsic factors (modified from Carlson's model 1995)

\section{INTRINSIC FACTORS}

\section{Writer's physical ability}

including thoughts about being good or not good at sport, being able or not able to perform during PE lessons, having fears concerning one's ability to cope in PE during the lessons

\section{Range of emotions}

including liking or disliking PE, feelings of embarrassment, and to attitude "showering situations "

\section{Beliefs about PE}

meaning what school PE should or should not be and the writers' guidelines for others concerning PE

\section{Sidesteps and explanations}

such as reasons for absences, experiences of peers, and other factors about sports outside school

\section{EXTRINSIC FACTORS}

\section{Teacher's personality and behavior} including liking or disliking the teacher, his/her behavior, the possibility for students to choose their activities during lessons, understood as autonomy given to the students by the teacher

\section{Curriculum}

including wide/narrow range of different sports, the number of lessons per week, different sporting occasions in the school or with other schools, the size of the class, and PE as a compulsory subject

\section{Class environment} including supportive / depressive feelings

8. Out-of-school influence and other factors including family and/or coaches

\section{Assessment}

including grades in school reports, rating and testing

\section{Facilities and equipment}

such as cross-country skis and skates, balls, and gyms and dressing rooms

\section{Examples of the factors}

"I've never been good at team sports and games that at school generally everybody else wanted to play." $(10,19,16)$

"I haven't had any lingering traumas from school PE

- I enjoyed the lessons a lot." $(7,9,25)$

"The purpose of PE lessons should be to find a suitable activity for everyone and not with the help of students who have sports as hobby to show up how clumsy and hopeless one is..." $(10,9,1)$

"On the other hand I don't remember many PE lessons in upper comprehensive school where I really bothered to participate. I dodged PE systematically." $(5,10,1)$

\section{Examples of the factors}

"The PE teacher in primary school was a horrible 50year-old woman who criticized me mercilessly. In upper comprehensive school it was much better and we had a SYMPATHETIC teacher who I really liked." $(10,9,19)$

"PE was terribly one-sided. Finnish baseball, floor ball, basketball, volleyball. Nothing novel or nice was ever tried out." $(5,10,71)$

"Although the others were just as utterly hopeless we nevertheless had a good crowd so that those who were worse were never dissed." $(5,10,29)$

"Luckily, in this school they take an understanding attitude to competitions. Even on parent's evening the head reminded everybody that you could attend competitions in school time." $(5,4,5)$

"I don't understand how on earth in school swimming there's any need for tests! We do Cooper swimming tests every year... " $(5,10,60)$

"Primary school was splinters in the soles of your feet and freezing water in the showers." $(5,10,28)$ 
Examples of the original phases analysed in this study are shown in Appendix 2. This summary of phase 3 of the analysis answered research question number two. The second sub-study (Article II) reported the results of this analysis, focusing on the extrinsic factors, while the third sub-study (Article III) focused on the intrinsic factors.

\section{Data II}

Phase 1: Qualitative content analysis (Patton 2002) was used and four groups, also called themes (Braun \& Clarke 2006), similar to those data I, were clearly identified. Data II also contained a group labelled "other", which I discarded because it did not directly concern the topic of this study, school PE (Braun \& Clarke 2006; Patton 2002, 466). To ensure trustworthiness, I sequentially coded the data within the space of three months. Unclear or ambiguous messages were again classified together with other members of the research team to guard against too much being read into unclear messages by one individual. (Figure 5)

One forum presented problems. The messages when copied for the data from the original Internet discussion forum page were unfinished due to their length exceeding the size of the readable space. I eliminated this whole forum from the data owing to uncertainty about the continuation of the message, and also to avoid excessive subjective interpretation by the researcher. Since this forum was the most difficult from the viewpoint of the analytical process used, it was used to check the consistency of the data coding. My supervisor and I analysed the same 100 messages independently and then compared our coding. The result showed 95\% agreement. Our objective in performing this checking procedure was to evaluate the trustworthiness of this qualitative content analysis. However, to ensure the credibility of the whole study, these 100 messages were not included in the final data. When all this was done, 1046 messages were left to be analysed further. In this summary, phase 1 of the analysis answers research question number one on the basis of data II.

The process of analyzing data II differed from the analytical process explained earlier in relation to data I. Since the positive and the negative messages included the same factors as analyzed and reported earlier and did not reveal any new factors, the focus of the study in data II was the messages in the group 'Both'. The interest after the analysis of data I was in the messages which included both positive and negative expressions, as these were the ones that challenge both the curriculum and the teacher to convert the negative opinions in the messages more into positive ones. This 'Both' was also the dominant group in data II, amounting to $49 \%$ of all the messages, and was thus expected to offer a new perspective on the possible factors tending towards engagement in or isolation from school PE. The main interest was to find out what factors were important if the overall orientation of the messages was to be changed. In other words, what influenced the writers' feelings regarding engagement in or alienation from school PE. The research unit remained one message, posted in a discussion forum. 
Phase 2: I reviewed and then recoded all the 'Both' messages $(n=515)$ into three groups: 'Mainly positive', 'Mainly negative' and 'Mixture of both positive and negative'. The 'Mainly positive' messages principally contained positive remarks about the subject, with only a small part or detail indicative of a negative opinion. Similarly, the 'Mainly negative' messages were chiefly negative but also included at least one specific positive point. The group 'Mixture of both positive and negative' comprised messages with a similar proposition of positive as negative opinions (see Appendix 2).

Phase 3: These messages I further grouped into intrinsic and extrinsic factors, following Carlson's alienation-nonalienation model (1995). As previously explained, I extended the original model developed by Carlson (1995) to include two other categories in this study, and was also suitable for grouping the 'Both' messages. A message that was 'Mainly positive' included one opinion or a statement that was negative (= research unit in this Phase 3). For example: "I've always had really nice and supportive PE teachers and even if you can't manage something its anyway enjoyable and the teacher helps. The only thing I don't like is swimming - it's horrible in my opinion." $(10,5,81)$ In such a message, I coded the negative part as an intrinsic or extrinsic factor. In this particular example, the part "...I don't like is swimming - it's horrible in my opinion", I coded as an extrinsic factor, and more specifically, curriculum. I took the same approach with the 'Mainly negative' messages. These messages included at least one part that was positive; that part of the message I coded as an intrinsic or extrinsic factor. In the 'Mixture of both positive and negative' messages what was coded was the main idea that arose from the message as a whole. These messages were coded as either positive or negative (Figure 5), and the positive or negative message content was coded as either intrinsic or extrinsic. In some cases, it was difficult to divide the message or decide between whether a factor was intrinsic or extrinsic. In these infrequent cases, the main impression gained from the message was the criterion for the classification. For example, showering moments I could have coded as extrinsic factors (facilities), but in these cases the feeling of shame was interpreted as more relevant, and hence I coded it as an intrinsic factor (range of emotions). The giving of PE grades in school reports were similarly treated; I coded these into intrinsic factors (physical ability), though they could as well have been coded as extrinsic factors (assessment). Examples with the original messages in these phases of these analyses are shown in Appendix 2.

The main focus in the fourth sub-study (Article IV) was to find the factors that tipped the balance from positive to negative, and vice versa, from possible alienation towards future engagement in school PE. All three phases were needed to be able to go deeper in the analysis. 
DATA I / 2007

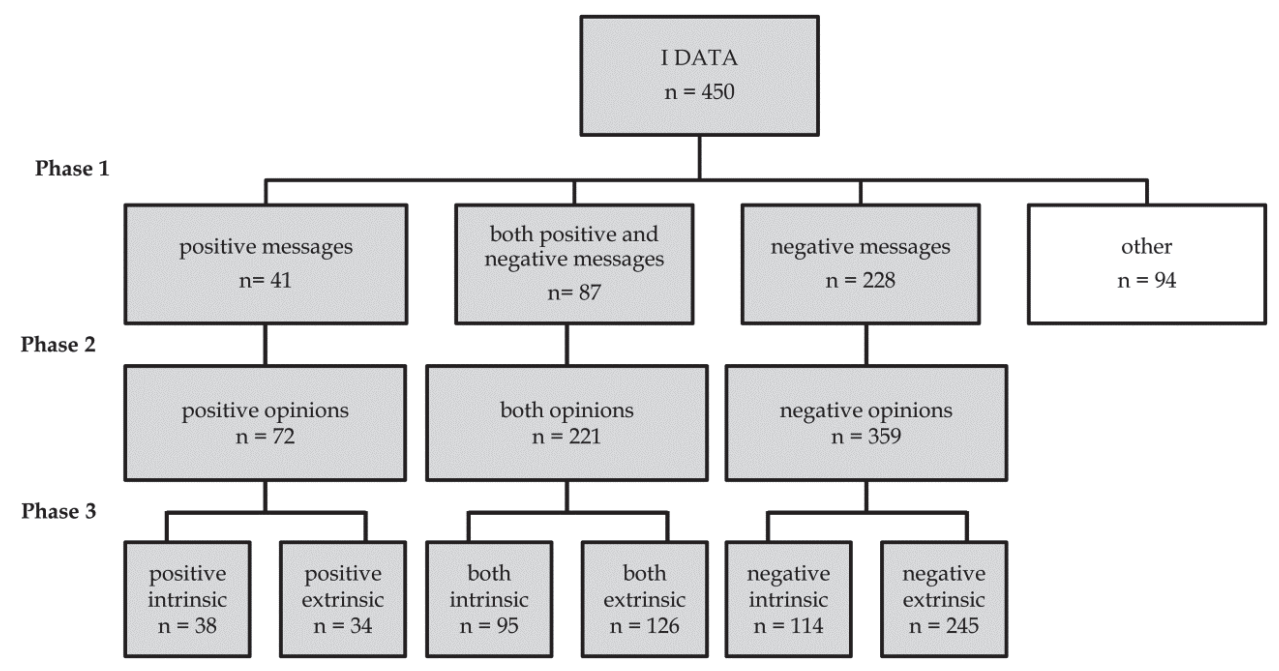

FIGURE 4 The data analytical process: data I / 2007

DATA II / 2012

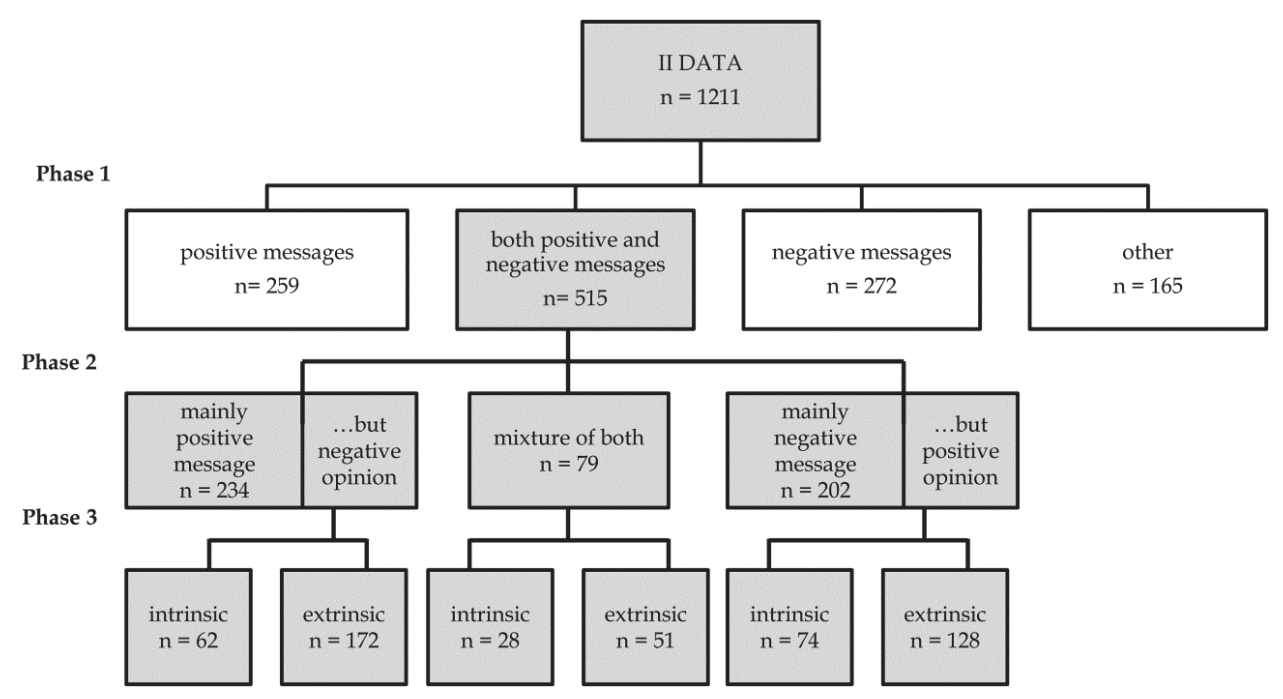

FIGURE 5 The data analytical process: data II / 2012 


\subsection{Ethical considerations}

The widespread use of the Internet can be seen as an index of present-day social and cultural life. The present era is characterized by a strong emphasis on individuality and individual ways of living. People tend to create networks via technological means instead of face-to-face social contacts. Screen time has increased significantly. The fact that the Internet plays such a central role in this study means that there are many ethical issues to consider. In general, the ethical principles that govern work offline also apply to online research (Moreno, Frost \& Christakis 2008). In both cases, the ethical considerations will depend on the nature of the research and on the target group (Basset \& O'Riordan 2002; King 1996). The topic of the present research project, school PE, was neither confidential nor private.

One basic ethical issue concerns the data collection. In collecting the data for the present study all the hits that led to the discussion forums were taken into consideration. All these Internet discussion sites were publicly accessible open forums, meaning that anyone could, at the same time as me, have opened the same messages whether as an active subscriber or as a passive reader. All the messages were clearly intended to be read by anyone, as they were sent and published in an open discussion forum. Discussions and opinions in these open forums exist independently of research purposes. Therefore no approach towards the forums' operators for permission to undertake the study was considered necessary (Eriksson 2013; Moreno, Frost \& Christakis 2008). It was purely by fortuitous that the selected forums were discussing school PE during that particular week. Informing all the writers of all the discussion forums about the research process would have been totally impossible, owing to both the number of writers and their pseudonyms.

In the full data, before any messages were discarded, there were many different pseudonyms $(n=265 /$ data I and $n=663$ / data II) posting these messages $(n=450$ / data I, and $n=1211$ / data II), so it is reasonable to assume that they reflect the opinions, experiences and/or feelings of more than just a few persons. The two data sets were collected during a randomly chosen week (week 15 in both data collections). The data collected in those weeks also included messages earlier sent to these forums, which means that reaching all the writers would have been impossible for that reason, as well.

One of the most critical ethical issues in research is to protect participants' anonymity (Ryen 2007). In this present study, to ensure that the writers in the original forums, along with their pseudonyms, remained anonymous from the very beginning of the research process, including taking into account the possibility that the same pseudonyms might have been used elsewhere (Bruckman 2002), all the writers behind the messages referred to in this study were given codes in which the first two digits indicate the discussion forum and the third the running number of the message. No claims about the writers' offline identities can be made. This study was not interested in finding answers to 
questions concerning the writers behind the messages. So it cannot be known who wrote a message or his or her background (age, gender, ethnicity, etc.). In addition, precisely when the writers experienced school PE varies and remains unknown. Graffigna, Bosio and Olson (2008) argue that retaining the original meanings and nuances when reporting the results may be problematic since the use of direct quotations means that they can be traced through the search engines online. In the present case, the original messages were written in Finnish, with the sole exception of the third sub-study (Article III), which was published in Finnish with the original quotations, all the quotations included here have been translated from Finnish into English by a native English speaking translator and cannot therefore be traced back as such. In this Finnish - English translation process the original forms of expression, along with possible writing errors, were retained to respect the code of ethics for translation in qualitative research (Patton 2002, 441).

The Internet can be seen as a form of cultural production where people build virtual persons and social images for the self and others (Basset \& O'Riordan 2002). In this study, in line with other researchers (see e.g. Bruckman 2002), the Internet is seen as a social environment for publishing one's thoughts and feelings. It is assumed for the purpose of this study, that, as Pitts (2004) states, Web forums and the messages in them are 'truthful' (see Hine 2000), and that the issues the writers raise are real for themselves. This cannot be proven and it may be ethically dubious, and thus remains unclear in this study.

In collecting the data from the Internet discussion forums, I had an assistant to help with the computer-based data files. The assistant transferred the original data from the Web sites into Word files. After being collected the data were filed in my office and stored in my computer behind my own keywords and passwords. Only my supervisors have seen the original data sets or a part of them since they were collected. In some unclear cases during the analytical process, we had to negotiate on the data together, and classify them as a team to guard against too much being read into unclear messages by one individual. Otherwise I alone have accessed the data.

My own position as simultaneously a researcher and a PE teacher was sometimes problematic, since some of the messages included information that, owing to my education and knowledge, I was able to identify and/or localize. It should be remembered that Finland is a small country with about 5.4 million inhabitants (Statistics Finland 2013), and since all secondary school PE teachers graduate from the same university where I studied and where I am currently working, it is obvious that some of the messages contained familiar names and places. In some messages, the writers mentioned their PE teachers by name. These cases were clearly treated with special care in order to protect individuals in those messages from being identified. In all cases I nevertheless worked according to good ethical principles (Finnish Advisory Board on Research Integrity 2012). As a physical educator myself, I can state that these issues are not new in school PE. I experienced something of these situations as a student years ago, and faced similar situations as a teacher afterwards. In this study, 
the fact that the messages existed in these open Web forums independently of this particular research purpose means that this could not have been known by, and thus not have influenced, the writers. I can only give my assurance that I have not been involved in any of these discussion forums as a writer myself. In the analytical process, I have tried to avoid drawing inferences from the messages, and have only read what was actually written. I have presented the findings of the sub-studies at national and international conferences. There my work has come under outside evaluation. This study is based on three published sub-studies (the fourth is currently under review), which also opened it to stringent feedback from unknown blind reviewers and to public criticism after publishing. I was the responsible researcher in collecting the data sets and analyzing them, and in each of the sub-studies I was the first author and my supervisors were co-authors. My supervisors took part in planning the study, planning the data collections and confirming the data analysis.

TABLE 2 Overview of the specific research questions, the research questions of each substudy, the data, and the analysis applied in each sub-study

\begin{tabular}{|c|c|c|c|c|}
\hline \multicolumn{5}{|c|}{$\begin{array}{l}\text { The main research task } \\
\text { What kinds of school PE experiences do people describe in Internet } \\
\text { discussion forums? }\end{array}$} \\
\hline $\begin{array}{l}\text { Research } \\
\text { questions in } \\
\text { this study }\end{array}$ & $\begin{array}{l}\text { Research } \\
\text { questions (1-3) } \\
\text { in the sub- } \\
\text { studies (I-IV) }\end{array}$ & The data & Analysis & Sub-study \\
\hline $\begin{array}{l}\text { 1. How is } \\
\text { school PE } \\
\text { described in } \\
\text { Internet } \\
\text { discussion } \\
\text { forums? }\end{array}$ & $\begin{array}{l}\text { What specific } \\
\text { experiences of } \\
\text { school PE are } \\
\text { described in } \\
\text { Internet } \\
\text { discussion } \\
\text { forums? (I, IV) }\end{array}$ & $\begin{array}{l}\text { Data I: } \\
\text { Discussion } \\
\text { forum } \\
\text { messages, } \\
\mathrm{n}=356 \\
\text { Data II: } \\
\text { Discussion } \\
\text { forum } \\
\text { messages } \\
\mathrm{n}=1046\end{array}$ & $\begin{array}{l}\text { Qualitative } \\
\text { content } \\
\text { analysis and } \\
\text { thematic } \\
\text { analysis, } \\
\text { Phase 1: } \\
\text { Positive; Both } \\
\text { positive and } \\
\text { negative; } \\
\text { Negative } \\
\text { messages }\end{array}$ & $\begin{array}{l}\text { Article I: } \\
\text { Student's voice } \\
\text { online: } \\
\text { Experiences of } \\
\text { PE in Finnish } \\
\text { schools } \\
\text { Article IV: } \\
\text { "PE at our } \\
\text { school has been } \\
\text { relatively } \\
\text { varied recently, } \\
\text { but...": Factors } \\
\text { of engagement } \\
\text { in or alienation } \\
\text { from school PE }\end{array}$ \\
\hline $\begin{array}{l}\text { 2. What factors } \\
\text { underlie the } \\
\text { various } \\
\text { opinions on } \\
\text { school PE in } \\
\text { Finnish schools } \\
\text { expressed in } \\
\text { Internet }\end{array}$ & $\begin{array}{l}\text { What kinds of } \\
\text { extrinsic / } \\
\text { intrinsic factors } \\
\text { underlie the } \\
\text { opinions } \\
\text { expressed in } \\
\text { Internet } \\
\text { discussion }\end{array}$ & $\begin{array}{l}\text { Data I: } \\
\text { Discussion } \\
\text { forum } \\
\text { messages (n= } \\
\text { 356), which } \\
\text { were divided } \\
\text { into smaller } \\
\text { segments and }\end{array}$ & $\begin{array}{l}\text { Qualitative } \\
\text { content } \\
\text { analysis and } \\
\text { thematic } \\
\text { analysis } \\
\text { Phase 2: the } \\
\text { messages were } \\
\text { divided into }\end{array}$ & $\begin{array}{l}\text { Article II: } \\
\text { School PE } \\
\text { through } \\
\text { Internet } \\
\text { discussion } \\
\text { forums } \\
\text { Article III: } \\
\text { Internetin }\end{array}$ \\
\hline
\end{tabular}




\begin{tabular}{|c|c|c|c|c|}
\hline $\begin{array}{l}\text { discussion } \\
\text { forums? }\end{array}$ & $\begin{array}{l}\text { forums on } \\
\text { experiences of } \\
\text { PE in Finnish } \\
\text { schools. (II, III) } \\
\text { What was the } \\
\text { role of the } \\
\text { teacher, class } \\
\text { environment, } \\
\text { curriculum and } \\
\text { assessment in } \\
\text { these } \\
\text { opinions?(II) } \\
\text { What kinds of } \\
\text { opinions and } \\
\text { feelings did } \\
\text { people describe } \\
\text { in Internet } \\
\text { discussion } \\
\text { forums? (III) }\end{array}$ & $\begin{array}{l}\text { termed } \\
\text { 'Opinions' } \\
\text { (total } n=652) \text { : } \\
\text { opinions } \\
\text { including } \\
\text { extrinsic } \\
\text { factors, } n=405 \text {; } \\
\text { opinions } \\
\text { including } \\
\text { intrinsic } \\
\text { factors, } n=247\end{array}$ & $\begin{array}{l}\text { smaller } \\
\text { segments or } \\
\text { research units, } \\
\text { termed } \\
\text { 'Opinions' } \\
\text { (total n=652). }\end{array}$ & $\begin{array}{l}\text { keskustelu- } \\
\text { palstalla } \\
\text { kirjoitetaan } \\
\text { koululiikun- } \\
\text { nasta: "Ja } \\
\text { kaikki näkee, } \\
\text { kun sä yrität" } \\
\text { [The Internet } \\
\text { discussion } \\
\text { forums retell } \\
\text { about school } \\
\text { PE: "And } \\
\text { everybody sees } \\
\text { when you're } \\
\text { trying"'] }\end{array}$ \\
\hline $\begin{array}{l}\text { 3. What factors, } \\
\text { mentioned in } \\
\text { the messages, } \\
\text { seem to lead } \\
\text { towards } \\
\text { engagement in } \\
\text { or alienation } \\
\text { from school } \\
\text { PE? }\end{array}$ & $\begin{array}{l}\text { What factors } \\
\text { seem to lead } \\
\text { writers to } \\
\text { include } \\
\text { negative } \\
\text { thoughts in } \\
\text { mainly positive } \\
\text { messages, and } \\
\text { vice versa? (IV) } \\
\text { What factors } \\
\text { would be } \\
\text { required in } \\
\text { these cases to } \\
\text { keep alive the } \\
\text { inborn drive to } \\
\text { be physically } \\
\text { active?(IV) }\end{array}$ & $\begin{array}{l}\text { Data II: } \\
\text { Discussion } \\
\text { forum } \\
\text { messages (total } \\
\mathrm{n}=1046 \text { ): } \\
\text { Both positive } \\
\text { and negative } \\
\text { messages, } \\
\mathrm{n}=515\end{array}$ & $\begin{array}{l}\text { Qualitative } \\
\text { content } \\
\text { analysis and } \\
\text { thematic } \\
\text { analysis } \\
\text { Phase 2: All the } \\
\text { 'Both' } \\
\text { messages (n = } \\
\text { 515) were } \\
\text { recoded into } \\
\text { three groups: } \\
\text { 'Mainly } \\
\text { positive', } \\
\text { 'Mainly } \\
\text { negative' and } \\
\text { 'Mixture of } \\
\text { both positive } \\
\text { and negative'. } \\
\text { Phase 3: These } \\
\text { messages (n= } \\
\text { 515) were } \\
\text { further } \\
\text { grouped into } \\
\text { intrinsic and } \\
\text { extrinsic } \\
\text { factors }\end{array}$ & $\begin{array}{l}\text { Article IV: } \\
\text { "PE at our } \\
\text { school has been } \\
\text { relatively } \\
\text { varied recently, } \\
\text { but...": Factors } \\
\text { of engagement } \\
\text { in or alienation } \\
\text { from school PE }\end{array}$ \\
\hline
\end{tabular}




\section{FINDINGS ACCORDING TO THE RESEARCH QUESTIONS}

This study aimed at achieving a broader understanding of how school PE is described in Internet discussion forums. PE teachers do valuable and challenging work with sensitive young people. In this study, people's voices were listened to through Internet discussion forums. Since the persons posting messages on the discussion forums remained unknown, they are called writers throughout this results section. This section summarizes the main findings of the study, which are discussed according to the research questions. The results are reflected on in light of the existing literature and previous research. At the end of each chapter, the results are also viewed from the Finnish cultural and national perspective. More detailed information can be found in the original sub-studies (Articles I-IV) along with the quotations from the primary data used in them, and in the appendices to this summary.

\subsection{School PE experiences in Internet discussion forums (I, IV)}

The first overarching research question focused on how the writers described their school PE experiences in the Internet discussion forums. The purpose was to gain an overview of the writers' experiences of PE in Finnish schools.

In data I (Article I), of the 356 messages, $12 \%(\mathrm{n}=41)$ were positive, $24 \%$ $(n=87)$ included both positive and negative observations and $64 \%(n=228)$ were negative. The messages posted on the Internet discussion forums studied here referred to negative experiences more frequently, and sometimes with vehement expressions of dislike of school PE, than has been previously reported in PE studies. This can be explained by the method used and thus, it may be unwarranted to compare these results with those obtained using different approaches.

In the messages labelled 'positive', the focus was on PE in general. The experiences described were more related to the writer him/herself than to 
external factors. Positive messages included statements about the writer's success in PE, the writer's development when his/her skills were not yet very advanced and also the writer's positive attitude towards the school PE as such. Good memories of PE teachers and their enthusiasm and assistance were also reported. The wide range of different sports, games and other physical activities in school PE, especially during the higher classes, the importance and the amount of school PE lessons, and good feelings regarding competitions between schools were also mentioned. What also seemed to be important was a good class atmosphere and environment, where the pupils felt accepted as a part of the group. Positive attitudes towards sport as a hobby were also notable.

In the messages labelled 'negative', the emphasis was more on issues external to the writer, such as the teacher or the other pupils, the curriculum, facilities and equipment, and, in particular, showering. The writers' messages revealed strongly held feelings and emotions. The teacher was the focus of most of these. The teacher's behavior was often mentioned. A common complaint was the teacher's attitude, which was even seen as 'Nazi-like'. Hate felt towards teachers was a common element. The teacher's way of teaching the subject or of treating the students was heavily criticized. The class environment, especially competitions and the depressing nature of the interaction between the students came up in many ways in a large number of messages. Being watched by other students when one was performing an exercise was a distasteful experience. Self-esteem was often mentioned from the points of view of bodily attractiveness and sports competence (Fox \& Corbin 1989). In particular, students who were more grown up and physically more mature than the others reported feelings of embarrassment. Physical fitness and an overweight body were often subjects of comparison, and thus a cause of negative experiences. Skills or the lack of them were also frequently mentioned. Some sports created strong negative feelings and anxiety that affected students' attitude towards PE as a whole during their school years. Team sports and ball games were most often mentioned, but individual sports received negative feedback as well. In this group of negative messages, the school PE facilities and equipment were also important things. Small gyms or the lack of a gym, unpleasant dressing rooms and showers, various items of sports equipment and the nuisance of having to carry them to school - as in the case of cross-country skis or ice skates - were highlighted. An interesting group of messages focused on the issue of the use of leather as a material used in the manufacture of sports equipment. Testing and evaluation, including grades for PE had also left bad memories in some of the writers' minds.

In data II (Article IV), of the 1046 messages, 25\% ( $\mathrm{n}=259)$ were positive and $26 \%(n=272)$ were negative. This was a clear difference compared with data I, where negative messages formed the largest group and positive messages were clearly the smallest group. In data II, the focus of the interest was on messages which were both positive and negative at the same time ('both'), since these were the ones that challenged both the curriculum and the teachers to convert the negative attitudes in the messages into positive ones. These messages also 
formed the largest group ( $49 \%, \mathrm{n}=515)$ in data II. The content analysis of the 'both' messages revealed that the curriculum played a crucial role in the writers' messages. In this study, the curriculum was understood to include the range of different sports the school offers as part of PE, the number of school PE lessons per week, different sporting occasions in the school or with other schools, the size of the class, and PE as a compulsory school subject. After the curriculum, in order of frequency were mentioned the teacher, the class environment, and the emotions experienced.

To summarize the present results as a whole, in data I the 'positive' messages formed the smallest group of messages; this result runs counter to the results of earlier studies (e.g. Carlson 1995; Dyson 2006; Nupponen et al. 2010; Palomäki \& Heikinaro-Johansson 2011; Rikard \& Banville 2006; Subramaniam \& Silverman 2007; Yli-Piipari, 2011). Within the group of 'positive' messages, the focus tended to be PE in general and personal experiences. The messages also dealt with the writer's good sport competence and general physical self-esteem. These results are in line with those of earlier international research (Groves \& Laws 2000; Rikard \& Banville 2006; Strean 2009). 'Negative' messages formed the largest group. In the negative messages, the emphasis was more on issues external to the writer, such as the teacher (Morgan \& Hansen 2008; Rikard \& Banville 2006; Strean 2009; Trout \& Graber 2009; Williams \& Bedward 2001) or the other pupils (e.g. Morgan \& Hansen 2008; Trout \& Graber 2009). In data II, in the 'Both' messages, which was the biggest group, the curriculum was clearly the most often raised topic (Carlson 1995; Gibbons \& Humbert 2008; Palomäki \& Heikinaro-Johansson 2011; Rikard \& Banville 2006).

In Finland, school PE is mainly taught to girls and boys in separate groups, which is not the case in many other countries (Annersted 2008). This may be one reason for messages in which the writer's motor competence, fitness and body were reported as comparing unfavourably with those of other students despite the fact that socialization and team work are more emphasized in the Finnish curriculum than they are in many other countries (HeikinaroJohansson \& Telama 2005).

\subsection{Factors underlying the opinions expressed in Internet discussion forums (II, III)}

The second overarching research question involved the kinds of factors that underlie the opinions expressed in Internet discussion forums on experiences of PE in Finnish schools. The aim was to examine what kinds of intrinsic and extrinsic factors can be identified in the forum writers' descriptions of their experiences of school PE and the range of feelings expressed towards it. The question, "What was the role of the teacher, class environment, curriculum and assessment in these opinions?" was also asked. Since in data I (Article II and III) each message could contain several sentences, opinions and meanings, the 
messages were divided into smaller segments termed 'Opinions'. This meant that since all the positive messages only contained positive views, these messages were all sub-divided into positive opinions. Similarly, the negative messages only comprised negative opinions. The group 'Both' contained both positive and negative opinions, and hence the sub-division contained both types. Thus, in these sub-studies (II and III), the research unit is an 'Opinion'.

The results revealed that, of the total of opinions $(n=652)$, 'Positive opinions' accounted for $11 \%(\mathrm{n}=72)$, 'Both positive and negative' for $34 \%$ $(n=221)$ and 'Negative opinions' for $55 \%(n=359)$. These were all subsequently categorized into either intrinsic $(38 \%, n=247)$ or extrinsic $(62 \%, n=405)$ factors. For more quantitative information, see Table 1 in Articles II and III.

The main finding for the intrinsic factors (Article III) was that nearly half of the opinions dealt with the writer's emotions towards school PE. In the 'Positive Opinions' category, school PE was described nice and enjoyable, not forced but relaxing and interesting. The writers stated that they liked PE lessons because they felt sure of themselves and able to do the given tasks. The results also revealed negative experiences about school PE. These were often expressed very powerfully. The antipathy towards school PE seemed to arise from strongly lived negative experiences, as was described with words like "traumatic" and "nightmare". The shame felt by having one's body on display, especially in the showers after lessons and in the context of swimming. Almost every fourth 'Opinion' included mention of the writer's perception of his/her own physical ability. This was clearly in line with the issue of being good or bad at school PE, which was often highlighted by reference to different sports. Beliefs about PE, meaning what school PE should or should not be, present both curricula and teachers with the challenge of how to render PE enjoyable, interesting and motivating instead of humiliating, compulsory and competitive. Sidesteps included various ways of explaining one's absence from PE lessons.

The main finding regarding the extrinsic factors (Article II) was that the teacher plays a crucial role in students' perceptions of their experience of school PE. The teacher's personality and behavior were the topics most often mentioned by the writers. Teachers' personalities were described with reference to age and appearance, professional ability, how sporty he/she was and personal characteristics that were considered important. According to the data, the teachers' professional skills varied between very skilled and very poor, and the descriptions of the teachers' character and relationship towards the pupils ranged very widely. Teachers' social and emotional understanding and interaction skills were highlighted in several 'Opinions'. Students' perceptions of their involvement in curricular decision making processes varied widely. Possibilities for students to choose what was taught in their school PE lesson or during the term were very few. Above all, very strong feelings of compulsion and humiliation were mentioned in most of the 'Opinions'. Almost every fourth 'Opinion' dealt with the class environment, where a supportive or a depressing atmosphere was the most common topic. Feeling good during school PE classes was mentioned in the context of telling about teachers' acceptance of students 
in school PE lessons and also outside them. Some writers had preferred the atmosphere during PE lessons in primary school, some just the opposite. Pressure to perform well seemed to start very early. The most often-mentioned single reason for negative experiences of the school PE class environment seemed to be the moments when the students were divided into teams or groups. In third place were issues related to the curriculum, where 'Opinions' varied widely, especially about the repertoire of different sports at different school levels. The most negative attitudes were expressed towards apparatus gymnastics, volleyball, skiing, orienteering, swimming and athletics. 'Opinions' about assessment were commonly against the numeral grades given in reports. Joy and the willingness to try were suppressed because of grading and fear of negative evaluation. The reasoning behind evaluations also seemed to be unclear to the writers. With respect to facilities, writers complained about the gyms or the classrooms used for PE, equipment in the gyms, and the shower rooms. Winter sports lessons and the angst associated with carrying skis or skates attracted much comment. The traumas of cross-country skiing were not related so clearly to the skiing itself but the uncomfortable business of transporting the skis on public transport between home and school.

The results of this study revealed that of the total 'Opinions' $(n=652)$, more than half were negative (55\%), and about two-thirds of the factors (62\%) mentioned in the 'Opinions' were extrinsic factors. In the other third, the intrinsic factors, the range of emotions reported was the dominant factor $(47 \%)$ (see Lintunen \& Gould 2013). Almost every fourth 'Opinion' in the group of intrinsic factors (24\%) included the writer's perception of his/her physical ability (Stiller \& Alfermann 2007; Yli-Piipari 2011). The analysis of the extrinsic factors showed clearly the central role of the teacher in students' enjoyment of school PE. The personality and behavior of the teacher (Graham 2008; Haerens et al. 2013; Owens \& Ennis 2005; Rink 2010; Strean 2009) was the most often mentioned extrinsic factor (40\%). Almost every fourth 'Opinion' brought up the class environment (Berg 2010; Morgan \& Hansen 2008; Strean 2009; Trout \& Graber 2009). In third place (16\%) among the extrinsic factors were issues related to the curriculum (Dismore \& Bailey 2010; Rikard \& Banville 2006). The identification of these three extrinsic factors supports earlier findings (Phillips 2011; Subramaniam and Silverman 2007).

The Finnish education policy is based on flexibility and loose standards, broad learning combined with creativity, and intelligent accountability with trust-based professionalism (Sahlberg 2007). In spite of this, many negative factors were found in these messages. Feelings towards teachers, in particular, were strongly expressed. 


\subsection{Factors, mentioned in the messages, that seemed to lead writers towards engagement in or alienation from PE (IV)}

The third research question examined how a small detail can be meaningful when talking about engagement in or alienation from school PE. The aim was to identify what factors influenced writers in the Internet forums to include negative thoughts in otherwise 'Mainly positive' messages, and vice versa. More specifically, what factors seemed to lead the writers of 'Mainly positive' messages to include negative thoughts that leaned towards disengagement? And vice versa, what factors would be required in these cases to keep their feelings on the side of engagement in PE, to keep them physically active? The research units studied to answer this question were the positive 'Opinions' in the 'Mainly negative' messages and the negative 'Opinions' in the 'Mainly positive' messages.

In data II, the 'Both' messages $(n=515)$ were recoded into three groups: 'Mainly positive', 'Mainly negative' and 'Mixture of both positive and negative'. The 'Mainly positive' messages contained principally positive writings about the subject, with a small part or detail that was negative. The 'Mainly negative' messages included one or more details that were positive, while the rest of the message was negative. The messages were then coded according to whether these factors were either intrinsic $(32 \%, \mathrm{n}=164)$ or extrinsic $(68 \%, \mathrm{n}=351)$ (for more detailed numbers, see Table 1 in the Article IV).

The results reveal the particular factors that seemed to lead the writers of the 'Mainly positive' messages also to include negative thoughts, and vice versa. The results showed clearly that curriculum was the main factor that affected writers' opinions. Here, curriculum was understood to include the wide or narrow range of different sports the school offers as part of PE, the number of school PE lessons per week, different sporting occasions in the school or with other schools, the size of the class, and PE as a compulsory school subject. Of all the 'Both' messages $(n=515)$, more than one-third $(35 \%)$ mentioned some aspects of the curriculum as a main factor. In the messages that were 'Mainly positive' the writers nevertheless complained about the narrow range of sports and annual repetition of the same activities. Also, even where the variety of activities was wide, the writers noted some that they did not like. Skiing, swimming and apparatus gymnastics were most often mentioned as disliked sports. Skating, Finnish baseball and floor ball followed, in that order. In the group 'Mainly negative' the three most often mentioned sports that induced positive feelings were Finnish baseball, swimming and dance. After the curriculum, in order of frequency, came the teacher, the class environment, and emotions.

The teacher and his/her behavior, mentioned in 13\% of all these 'Both' messages, was the next factor. Teachers' personalities were described broadly, especially their characteristics, age and appearance. In the 'Mainly positive' messages, the teacher and his/her behavior was often in any case described 
negatively. On the other hand, many different positive words were used to describe the personality of teachers in the 'Mainly negative' messages. Many writers described their teacher as "nice" and/or "young. One teacher behavior that the writers liked was supportiveness. PE lessons were also comfortable when the teacher did not demand or force the students to do something.

Class environment was mentioned particularly often in the 'Mainly positive' messages as a negative factor. Many writers were frustrated by and disappointed with their classmates' behavior during PE lessons. Students not trying to do the given task or just hanging around while the others wanted to play or concentrate on the activity was a cause of complaint. The atmosphere in the class in general, students teasing or humiliating other students, was also noticeable in these messages. In the 'Mainly negative' messages some writers were nevertheless slightly positive about their school PE groups, writing that they were nearly always quite decent.

What the writers reported second most often in the 'Mainly negative' messages was their emotions. These ranged from extreme liking to extreme disliking for PE or sports in general. Many writers in both the 'Mainly positive' and 'Mainly negative' groups stated that he/she liked or even loved sports and physical activity, but only outside school. PE at school was something these writers disliked intensely. Some writers stated that they only started to feel the joy of sport after leaving school, most obviously because of the lack of student autonomy coupled with a strongly authoritarian teacher. These results support earlier findings (Berg 2010; Dismore \& Bailey 2010; Tischler \& McCaughtry 2011). The present results showed clearly that the curriculum was the main factor that affected writers' opinions. The importance of the curriculum has also emerged in previous research (Cothran 2010; Dismore and Bailey 2010; Palomäki \& Heikinaro-Johansson 2011; Rikard \& Banville 2006; Tischler \& McCaughtry 2011). After the curriculum, in order of the frequency, were the teacher, the class environment, and emotions. Many earlier studies have reported results similar to these on the role of the teacher in the educational setting (e.g. Cothran 2010; Haerens et al. 2013; Rikard \& Banville 2006; Strean 2009). Also, research on the class environment has reported many similarities with the present findings (e.g. Ferry, McCaughtry \& Hodges Kulinna 2011; Strean 2009).

In the curriculum and the physical activities within it, the Finnish national culture played a crucial role. Swimming as a specific skill mentioned in the curriculum in this 'country of a thousand lakes' prompt opinions both for and against. Strong feelings about both winter sports, and carrying the equipment needed to practice them, and the spring about Finnish baseball were evident in these opinions. 


\section{GENERAL DISCUSSION}

The aim of this study was to investigate experiences of school PE described in Internet discussion forums. The results underlined the important role played by emotions during school PE. The use of open discussion forums as the source of data was seen as an additional, nontraditional, possibility to listen to people's voices. This section discusses the theoretical implications of the main findings. Also considered are the practical implications of the study along with methodological reflections and the issue of the trustworthiness of the findings. The section closes with a discussion of some of the challenges for future research.

\subsection{Main findings and theoretical implications}

First of all, it was interesting to notice such a large number of negative descriptions and opinions contained within the messages posted on the Internet discussion forums studied. In the first part of this study (data I), in particular, in the messages on the Internet discussion forums with the expressions used showed a strong negative bias. This result was unexpected and quite the opposite of the largely positive picture of school PE reported earlier. Several previous studies have shown that PE is generally a popular subject in schools (e.g. Dyson 2006; Liukkonen et al. 2010; Palomäki \& Heikinaro-Johansson 2011). In the second part of this study (data II), the number of messages including both positive and negative comments were emphasized, and the focus was on the curriculum, teachers, the class environment, and the range of emotions.

However, it should be emphasized when seeking to interpret the results that the views expressed are those of writers in Internet discussion forums, and therefore not representative of all school students or all people. The Internet as an anonymous forum offers an easy opportunity for the expression of strong feelings and extreme views. As a data source, however, the Internet has the advantage that it enables people to describe experiences that might sometimes 
be too personal to be voiced by other means. The methodological conclusions are discussed in greater depth in the next section of this chapter. This study was based on pedagogical research on school PE and sport science, and the main research task was to find out and analyze the kinds of experiences of school PE people describe on Internet discussion forums.

The main findings yielded by the analysis of the often rather negative and strongly worded messages were concerned the themes the writers sent into cyberspace. These are discussed below.

\subsubsection{Negative messages}

Two existing models, those of Carlson (1995) and Stodden et al. (2008), basically share the same concern regarding the possibility of the student either being alienated from PE (Carlson 1995), or being in the negative spiral of disengagement from physical activity (Stodden et al. 2008). This concern also arose in the present study. The student-centered approach taken towards school PE in this study was underlined in the first research question, which addressed how people described school their experiences of PE in Internet discussion forums. The answer can be summed up as mainly negative and expressed in strong language. The earlier research on students' attitudes to school PE have usually yielded positive results, although, negative feelings have also been expressed. Based on the two models mentioned above, the importance of the student's own physical ability and perceived motor competence cannot be underestimated. A student who feels sure of him/herself and of his/her physical ability is likely to have a more realistic self-perception of motor competence, which in turn can lead to positive physical self-esteem (Fox 1997). This is the basis on which a student makes the choice of whether to choose the path of nonalienation or the path of alienation (Carlson 1995). It is also a good predictor of physical activity, which has been shown to lead to a positive spiral of engagement (Stodden et al. 2008). Students with negative memories and who post negative messages, including their thoughts about being not good at sport, being not able to perform during PE lessons and having fears concerning their ability to cope in PE during the lessons, may be led to disengage from physical activity and even to become alienated from PE. In this study, the negative messages posted challenge teachers to re-evaluate their chosen activities, methods and social skills so as to promote an increase in the number of students reporting positive experiences of school PE.

With respect to the negative messages in general, it may be that individuals are many times more likely to report a negative experience than a positive experience. Thus the frequency of negative comments may be an artifact of motivation to participate in Internet forums rather than a reflection of the overall experience of students in PE. 


\subsubsection{Extrinsic factors}

Despite sometimes very strong expressions of dislike for PE, it is all the more important for pedagogical reasons to understand the personal situations that underlie students' opinions, whether negative or positive. The second research question focused on the specific factors underlying opinions expressed in the Internet discussion forums on experiences of PE in Finnish schools. The main categorized factors that emerged from these discussion forum messages were mainly extrinsic (Carlson 1995): teachers first, followed by the class environment and the curriculum.

Teacher. The most often mentioned extrinsic factor in order of frequency was the teacher. Good 'personhood' in a teacher can be described by positive attributes like caring, involved, present, fair and individualised (Strean 2009). The same themes were found in this study. In former studies teachers who had good socio-emotional skills before, during and after PE lessons (see Ferry, McCaughtry \& Hodges Kulinna 2011) were liked and wished for (Klemola 2009). They gave their students time, and were caring and understanding (Louhela 2012). Unfortunately, this was not always the case. Strong feelings of compulsion and humiliation were mentioned in most of the negative 'Opinions'. It is important that teachers offer all their students the possibility to experience competition, success and achievement without serious injury or humiliation (Constantinou, Manson \& Silverman 2009). And they should be able to offer students the kind of tasks that induce feelings of competence in students. Despite their observable fear, some writers were worried that the teacher would force them to do difficult tasks they felt were beyond their ability. The personal value a student attributes to school PE also depends on the way the teacher has approached and delivered the content, which according to these messages was not always successful. Hence, widening the range of sports and other physical activities in teachers' lesson plans would help students to find something on the curriculum that they can enjoy (Cothran 2010; Rikard \& Banville 2006; Tischler \& McCaughtry 2011) both at school and in the future (Gibbons \& Humbert 2008). By looking at PE from the perspective of the individual student and using social interaction skills, a teacher can resolve possible conflicts in a positive and a constructive way (Klemola 2009). The teacher and his/her behavior are under constant critical evaluation in educational settings. I believe that most teachers do their best to achieve all the goals set for school PE. But they cannot please all the students. For some people, PE encapsulates their unhappiest memories of school. Nowadays, however, research in the field of sport psychology has helped us to understand possible coping strategies for teachers during PE lessons (Liukkonen, Vanden Auweele, Vereijken, Alfermann \& Theodorakis 2007).

Class environment. With respect to the class environment, the role of the other students present is also important (Dismore \& Bailey 2010; Strean 2009). According to some messages the environment felt safe, the students were able to enjoy the lesson, have fun and also fail in a supported way. Sadly, once 
again, this was not always the case in these messages. Social isolation emerged in a large proportion of the messages concerning the class environment. Fear of being embarrassed in front of the other students was clearly present in the posted opinions. The importance of friends (Strean 2009) is also crucial in the challenging situations of dividing students into teams (Berg 2010; Rink 2010), which also in this study was one of the most unpleasantly experienced parts of the lesson.

Curriculum. The messages and opinions in this study showed clearly that the curriculum was an important factor informing writers' opinions. This was particularly evident with regard to the third research question, which focused on the factors that seemed to lead writers towards possible engagement in or alienation from school PE. Lack of control was a major curriculum complaint. Writers' views on what should be included, especially the repertoire of individual sports varied widely: what for one writer was the most liked activity was the most disliked for another. In Finland, a lot also depends on the value placed on the role of PE in their schools by the school principal (Pulkkinen 2011). In the current financial climate, many schools are facing a situation where the principal has to make hard choices regarding what facilities and equipment, extra-curricular activities and class sizes can be afforded. In the messages studied here, some writers mentioned ordinary classrooms being used as gyms; these were probably older individuals, as this practice is no longer so common in Finland.

\subsubsection{Intrinsic factors}

The emotions evoked by school PE was the most frequently mentioned intrinsic factor in the messages, and clearly influence the meaning and value accorded to school PE.

Range of emotions. School PE is known to be a very sensitive subject. The present findings made it very clear that PE does not provide enjoyable experiences and happy memories for every student. According to Lintunen and Gould (2013), emotions are always present in sports. The present results bear this out on the level of school PE. The results indicated that behind many writers' messages lay a deeply felt human experience. Negative descriptions of PE experiences quite often include the word "traumatic". Unlike in most of the other school subjects, the outcome of the task cannot be separated from the person (Olafson 2002). This is arguably the reason why classroom situations and evaluations of school PE are experienced so emotionally. Feedback from the teacher and other students is felt to be targeted at the student personally rather than at his/her performance, so that, as one writer expressed it, the feeling of being good or bad is "me and not my forward roll". Students' selfperceived motor competence and self-rating of performance may be inaccurate and an underestimate of their true ability.

The posts in which writers described their feelings of shame connected to their bodies, clearly demonstrated their feelings of uncertainty and ambivalence. Underlying these feelings could have been pressure to conform 
(Kenway \& Bullen 2001), since self-acceptance is also related to the cultural values of the surrounding society. Meaningful experiences arise from sensitive situations. A challenge for teachers is to create a learning atmosphere in which different persons and values are accepted. If this is not accomplished, the risk remains that in school PE the idea of a human being is based solely on physical achievements. Trusting oneself and others creates a positive environment and an atmosphere in which there is space for different emotions (Barkoukis 2007). These things effect the decisions people make in relation to school PE and, further, to the lifestyle they adopt. Sidesteps and explanations indirectly express negative feelings and avoidance behavior, a negative attitude at moments when there is no interest in even trying.

Bad memories of one's body image and physical self-esteem (Fox \& Corbin 1989) and feelings of hurt caused by failure, or criticism from a teacher or peers, may remain with the writer for life (Olafson 2002; Strean 2009). The emotions that emerged in this study highlight a serious issue: regardless of whether their opinions were positive or negative, many writers claimed to love physical activity while hating school PE (see also Tischler \& McCaughtry 2011). PE educators seriously need to look in the mirror and ask what reasons there might be for this, and what could be done to change the views of the writers of such messages.

Attempts to combat global concerns over sedentary lifestyle and increase in overweight (McKenzie 2007) by health-related PE aiming to promote lifelong physical activity are currently being implemented. To extend the possibility for success in promoting a physically active lifestyle through school PE, different curricular models have been developed internationally. In Finland, Finnish Schools on the Move is a national action program that aims to establish a physically active culture. In Finland, as mentioned earlier, the national school PE curriculum sets guidelines for teachers regarding the values, principles, aims and goals, contexts, teaching methods and evaluation of school PE, along with educational support. This ongoing reform is thus an important step which will influence all the future students in the country.

Outside school, the way students spend their leisure time is changing. Today, the meaning students ascribe to physical activity and sport in daily life has changed (Kauravaara 2013) along with the prevalence of a more sedentary lifestyle featuring different possibilities of being active online. The present-day consumer-media culture modifies the thinking and understanding of young people (Kenway \& Bullen, 2001). For example, social media from time to time invites discussion and is forever reminding subscribers about the negative experiences of school PE reported by different, mainly popular and well-known people.

\subsubsection{Findings in relation to the model of Bronfenbrenner}

Applying Bronfenbrenner $(1979,1989,1994)$, school PE is not an isolated island detached from the surrounding mainland, but has a strong influence on students' possible engagement in a physically active lifestyle. A closer look at 
the curricular sector (Figure 2) shows how at different levels the curriculum mediates the general cultural values held during the individual's lifespan. The cultural values conveyed via the national curriculum, in turn influence other layers. These values are adapted to the needs of local schools, and are then manifested in the lesson plans drawn up by teachers for their students, who all experience them in their own ways. Nowadays, the power of media is not to be forgotten. Nearly all students are influenced by social media whether they wish it or not, and in this here that the Internet plays a key role.

The Internet can, like the teacher, also be seen as one of immediate influences on the students, since it plays so important a role in today's lifestyle (Statistics Finland 2013). During the last few years, some schools in Finland have even given their students tablet computers for use during their studies. Access to and the use of the Internet during lessons have been incorporated into schools' teaching programs recently, and a specific strategy for this has been published (Information and Communication Technology Strategy of the Finnish Teacher Training Schools Consortium 2013-2016). Nowadays, communication through the Internet and Internet discussion forums are ways of being social and participating, as shown by the number of messages and pseudonyms posted in this study. Since, during their leisure time, younger audiences are more and more occupied with social media environments, such as Internet spaces, cyberspace offers them, among other things, new tools for selfassessment and self-surveillance (Rich \& Miah 2009). According to Pitts (2004), the Internet can be a medium for affirming the norms of consumerism, individualism and other social messages. Such messages also include risks for distorting the picture one has about one's body and about what constitutes normal healthy life. Cultural values become slowly customized over time. Therefore one approach to gaining a better understand of how students experience their lives today is to listen to their voices, such as in Internet discussion forums.

\subsection{Practical implications}

Based on the results of this study, it can be concluded that it would be important to focus more closely on the pedagogical and emotional aspects of the learning environment. The experiences and memories students take with them from school PE can be influenced by taking the student sensitively into consideration. Respecting students and their opinions by giving them more autonomy and more choice (Carlson 1995; Spencer-Cavaliere \& Rintoul 2012) with respect to the tasks assigned in PE are basic prerequisites for promoting engagement in school PE and a subsequent physically active lifestyle. Teachers can influence the practical decisions made during the curriculum planning and during the actual lesson. How the goals set for school PE are reached will also depend on the way the content is delivered. If the teacher is successful in creating a positive and a safe learning atmosphere, then no student need feel 
fear of failure. This in turn will have a positive impact on both observed and perceived motor competence, which together could have a positive effect on overall physical activity. It seems that, owing to resource constraints, the size of classes is likely to increase in the future, since the existing guideline on the maximum number of students in a PE class is unclear. When these decisions are being made, the safety and individual needs of students should not be forgotten or underestimated.

This research was carried out in the context of school system in Finland, where the national core curriculum for basic education (2004) is presently in the process of reform (Finnish National Board of Education 2013). A serious question is: What should be retained from the former curriculum and what should be different in the future curriculum? The findings of this study indicate that school PE does not succeed in promoting a physically active lifestyle among all students. According to the messages in this study, the curriculum plays a crucial role in how students feel towards school PE. The decisions made in this reform will be read in the online messages of future students. Since the overall mission of basic education in Finland includes the principle that school PE must be provided for all children, meaning that it must be genuinely inclusive, students with special needs must also be supported. The diversity of the students in the classes presents an ever-increasing challenge.

The teacher education has an important position in the training of future teachers. As these results show, the personality of the teacher was repeatedly mentioned. In Finland, both in teacher education and in PE teacher education, negotiation on the reform of the curriculum is ongoing. How knowledge can be delivered and acquired, without forgetting the importance of pedagogic and social interaction skills, is essential central question. In the current financial situation, the potential risk is that by heavily cutting contact lessons, future teachers will lack sufficient motor skills, possibly causing them to feel a lack of confidence, and thus uncertainty, in facing their classes (Siedentop 2002). Teacher training practice in real schools will, it is to be hoped, keep its important position in the teacher training system, since it involves a connection with the real world, one in which the student teacher can learn to interact with pupils in a natural environment. It also remains to be seen how successful inservice training will be in meeting the needs of the 'net generation'.

As concluded earlier, a closer focus is needed on the pedagogical and emotional aspects of the learning environment. In teacher education, both for class teachers and PE subject teachers, it should be ensured that all future teachers have the willingness and understanding necessary to assume a strong educator role. They should care about their students and have good socioemotional skills before, during and after PE lessons (see Ferry, McCaughtry \& Hodges Kulinna 2011). They should also have the requisite tools for creating a safe class environment in which, where events that have the potential to cause negative feelings can be avoided (such as when dividing the class into teams, or different testing situations). This has strong implications for the development of university entrance examinations that are able to select the best, most 
pedagogically orientated and motivated, students from the huge numbers of candidates. Can the best and most suitable students be found using the present protocol or should radical new selection methods be applied? According to the messages posted in this study, work remains to be done on this topic.

\subsection{Methodological reflections}

Reflecting on the methodology used in this study, it can be assumed first, that the result can at least partly be explained by the method used, in which the writers were able to express their feelings and emotions anonymously. Another explanation could be the way the data sets were analyzed. In this thematically grouped (Braun \& Clarke 2006) qualitative content analysis (Patton 2002), every positive or negative message, and in some phases also the positive or the negative part of the message ('Opinion') was taken into consideration. Such a detailed classification has not often been used in studies on school PE. This study is based on pedagogical research on school PE and sport science. This means that the approach is not a linguistic one, despite the fact that the research data comprise original Internet discussion forum posts, where the language used could also have been evaluated (see Kytölä 2013).

When talking about the data, the question of presentation and representation come to the point. Applying Bruner (1987), the 're' prefix does not mean re-product of the reality but the product itself. Bruner (1987) separated three ways of seeing the reality, which were lived life, experienced life and storied life. This was the approach taken in this study, where the Internet was seen as a social environment for publishing one's thoughts and feelings, and where the messages were considered to be 'truthful' and to be meaningful and real for their writers. In the messages comprising this data set, the experiences themselves and their linguistic descriptions were chosen by the writer on the basis of his/her own lived experience, which he/she wished to share with others in the discussion forum. My task as a researcher is not to interpret the message, but only to read what is actually written on it, and this way try to exclude myself along with my own experiences. I also wanted to avoid personal interpretation, in light of the fact that I belong to an age cohort preceding that of today's digi-natives. This was the reason for using content analysis rather than a narratological or phenomenological type of the data analytical method.

\subsubsection{Participants in the discussion forums}

Some limitations in this study should be acknowledged. The first concerns the data, i.e. the posts by the participants in the discussion forums. The identity of the person writing the message behind the computer was unknown. It is possible that some of them, as Tapscott $(2009,3)$ argues, were "screenagers, Net addicted, losing their social skills, and they have no time for sports or healthy 
activities. Time spent online could have been devoted to sports and face-to-face conversation; the result is a generation of awkward, fat people" (see also Oblinger \& Oblinger 2005). If that is the case, it might mean that these individuals have difficulties coming to terms with the normal and natural reactions of their own body during or after exercising and feel uncomfortable with it. This may explain their particular bodily feelings and experiences after physical activity and/or an extreme sensitivity towards these feelings (for example sweating and increased heart rate).

Since the participants on Internet forums write anonymously, it is impossible to know their cultural background, ethnicity, schooling, gender or age. In the full data, there were so many different pseudonyms $(n=928)$ posting these messages $(n=1661)$, that it seems reasonable to assume that they reflect the opinions, experiences and or feelings of a large number of people. Given these numbers of different pseudonyms above these posted messages, talk about "superparticipants" (see Graham \& Wright 2013) and their impact on this debate is not applicable. In some studies, researchers investigate a topic in a specific forum specially set up for the purpose. This was not the case in this study. Discussions and opinions exist in forums independently of research purposes. Data collected in this way are totally unaffected by social pressure (Yun \& Park 2011) or the need to please interviewers or teachers (cf. Seale et al. 2010). Also for this reason all the facts about the writers and their background remain unknown. That is the reason why no approach towards the forums' operators for permission to undertake the study was considered necessary (Eriksson 2013; Moreno, Frost \& Christakis 2008). Informing all the writers of all the discussion forums about the research process would have been totally impossible due to the large number of writers, or being more exact, pseudonyms involved. From a methodological perspective, as data the Internet discussion forum messages were not unambiguous. The question of the writers' identities remained unknown throughout the process. People join online forums for all sorts of reasons. Who the writers were, what their motives for expressing themselves in the discussion forums were, and what they were aiming at with their messages, are questions that cannot be answered within this study.

Another issue related to the views expressed by the writers is what influences their posts. For example, in this study, conducted in Finland, girls and boys mostly do school PE separately from the third grade (8-9 years of age) onwards. This may have influenced the views of some of the writers. Another question that arises concerns possible trolling and flaming. However, there may be an unwritten imperative in forums to compete with previous writers and make one's experiences sound even worse or better than theirs (Hagger, Wood, Stiff \& Chatzisarantis 2009). It may be that the Internet encourages more forthright expression and that negative examples fuel the effects of other writers. Also, provocative messages (trolling) might be posted with the express purpose of inciting strong reactions (flaming) from people (Millard 1997; Tepper 1997). The question of why someone writes on a discussion forum 
remains unclear. Has the writer him/herself lived through the experience, has it happened to someone else, or was it only a product of the imagination? Were the feelings, experiences and factors in the messages exaggerated, or just the opposite, understated? Is holding a minority opinion on the topic of a thread conducive to a spiral of silence (see e.g. Yun \& Park 2011)? These questions were not a focus in this study, so thus remain open. To obtain the most inclusive view of these phenomena, different data collection methods would need to be used in combination. This study was conducted on the principle that the writers' experience was trustworthy. In analysing the data, no critical position was taken regarding the veracity of the message. The main purpose was to listen to the writers' voices online, to hear whatever it was that they wanted to draw attention to and for whatever reason (Arpo 2005). Issues concerning the writer's personal background were not within the scope of this study, and should therefore be examined in future research.

Second, in relation to discussion forums, it is important to understand that only a limited population segment find such sites, read the messages posted and react. In Finland, however, quite a large number of people use Web forums. When this research commenced in 2007 , about $75 \%$ of the people had the access to the Internet at home, and the proportion of Internet users under age 40 was already almost $100 \%$. The difference between men and women was only a few per cent (Statistics Finland 2007). Among the Internet users, 29\% used the net for chat or discussion forums (Statistics Finland 2007). By the time of data II in 2012, the proportion of Internet users had risen to $90 \%$ among those aged 16-74 years and $87 \%$ of the population had the access to Internet at home (Statistics Finland 2012).

The present results are based on all the messages posted in nine (data I) and 26 (data II) Web forums during the specific periods mentioned earlier. The writers were commenting on a rather broad topic. The search term "school PE" sounds broad, but in Finland and in Finnish context it is understood clearly to mean school PE lessons and everything connected to those curriculum-based teaching hours, as explained earlier.

The Internet is one way of listening to people's voices. This presents the researcher with various challenges when seeking to decode the data. One such challenge is to be able to access the writer's feelings. Another challenge is to understand and construe a message the way it can be assumed the writer intended. The smilies and other emoticons used in the messages helped in arriving at an interpretation of the writer's feelings (Hersberger, Murray \& Rioux 2007). The threads forming the conversations in these data sets (I and II) were not always clear or easy to follow. A message did not always receive a reaction. Instead, the writer started a new topic that was more relevant from his/her point of view. As stated earlier in the Method section, one forum in data II presented problems and was eliminated from the data to avoid researcher interpretation. In that forum, the length of the messages, when copied for the data, exceeded the size of the allotted window, meaning that in these cases the reader of the analyses would be left with uncertainty regarding 
the continuation of the message. Since this forum was the most difficult from the viewpoint of the analytical process used, it was used to run a focused test to check the consistency of the data coding. The 100 messages making up the forum with was coded and analysed independently by two persons from our research team. The codings were compared and the result showed 95\% agreement. Since enough data had already been obtained, and the issues and themes seemed already to be saturated (Patton 2002, 466), these 'unclear' messages were considered redundant. Moreover, to ensure the credibility of the study, these messages were not included in the final data.

\subsubsection{The trustworthiness of the study}

The methodological decision was made to apply qualitative content analysis (Patton 2002) supported by the thematic analysis (Braun \& Clarke 2006). Other alternatives were discussed in the planning stage, but this descriptive analysis emerged as the best choice for this study and for these research questions. Since the data were based on open Internet discussion forum messages, a more interpretive or deeper approach was not possible, as has been explained earlier. The distinction between intrinsic and extrinsic factors presented in Carlson's model (1995), which had already been adapted for PE, seemed a suitable preexisting theoretical framework for grouping the 'Opinions'. The rest of Carlson's model was not applied in this study. Carlson classified the factors that were known to have an impact on students' feelings towards PE into two groups: intrinsic and extrinsic (Carlson 1995). This distinction was not always unambiguous. For example, a particular physical activity, coded as an extrinsic factor, could instead have been be something a student was motivated, to participate in, and hence an intrinsic factor. An intertwined ecology, with student personal, teacher/curricular, social/environmental, informing and being informed by one another, might have worked at least as well in this study. Carlson's model (1995) can also be criticized, for possibly oversimplifying complex phenomena, turning something better considered along a continuum into a dichotomous outcome. This model can also be seen from a time perspective, meaning that the model does not as such cover the needs of today's generation and their school PE. When listening to people's voices in analysing the messages in this study, new categories were needed to extend the original model.

The references used in this study were mostly relatively new, mainly from about the last ten years. This was purpose deliberate strategy applied to reflect the time within this study was done, and also the years that affected the writers of these messages, the "screenagers" described by Tapscott (2009). The prevailing lifestyle and its consequences might have influenced the other recent studies consulted. While similarities were found between the studies from the earlier decades and this study, differences also emerged: for example a different focus on one's body (Siljamäki 2013) or the meaning attributed to physical activity and sport in daily life (Kauravaara 2013). Parallel issues are being discussed internationally as well. 
Some changes were observed in the Internet discussion forums during the years between data I (2007) and data II (2012). In data I, with Google ${ }^{\mathrm{TM}}$ search, nine discussion forums appeared within the first 200 hits, whereas five years later the same sampling found as many as 26 forums. Data collection checking was re-organized during week 15 in April 2013. This meant that five different persons with nine different computers (each using Internet Explorer, Mozilla Firefox and Chrome) with five different usernames and passwords each collected the first 200 hits with the term "koululiikunta" ["school PE" in English] via Google ${ }^{\mathrm{TM}}$ search. This was done to guarantee that the computer I was working with did not affect the data collection. It is claimed that Google ${ }^{\mathrm{TM}}$ search 'learns' to show hits according former searches, so called 'gets used to certain searches'. This was now checked by these different computers, usernames and passwords. The result showed that 19 different discussion forums were found by my data collection computer in the 200 first hits. In comparison to this, two out of the eight other searches missed between one and three forums, and six others found the exact same forums as my computer. Interestingly, four searches found 15 or 16 additional forums compared to the ones I collected with my computer. It was concluded that my computer had not 'learned' to search for more discussion forums. Further, more forums were not needed because the data seemed already to be saturated.

The use of Internet forums with other school subjects was also implemented to enlarge the database during summer 2012. School PE is often combined together with music (and visual arts) as skill-based sensitive school subjects. In each of these subjects the knowhow is visible and public. For that reason a Google ${ }^{\mathrm{TM}}$ search of school music in Finnish was done with two different search terms. The first 200 hits with the first term yielded only two forums, comprising 34 messages, whereas the second term yielded six discussion forums, comprising 154 messages. Another subject which from time to time arises is the subject Swedish language, the other (minority) official language in Finland. With two different search terms, "compulsory Swedish" ["pakkoruotsi" in Finnish] and "school Swedish" ["kouluruotsi" in Finnish], the first 200 hits found 56 forums $(18+36)$ and a total of 5680 messages. The data collected from these two other subject forums are introduced in more detail in Appendix 3. Thus, while a lot is written about school PE in Internet discussion forums, it is not necessarily the most popular topic.

Reflection on Finnish society during the research period should not be omitted. The main focus in this study was not to compare the two data sets (I and II). Nevertheless, it is that the numbers of writers/pseudonyms, messages and the discussion forums increased during this five-year period. Also, results show changes in the way messages are written. In data I, the forums sometimes included extremely strong and aggressive messages while in data II, the messages seemed more neutral.

The Internet has become increasingly used in very negative circumstances, too. Quite soon after the data I collection, the Jokela school shootings took place (7 November 2007). This was the first, but unfortunately not the last, such 
occasion in Finland. At around that time, the Internet and the writings on it began to receive a lot more attention, and people started to think about the role of Internet as a place for social community. Anonymous 'hate speech' also started to exist online (Eriksson 2013). Luckily, a lot has now been done also to combat it (Council of Europe 2012) and a social code of preventing harm on the Internet, Netiquette, has been created.

In addition to all this, it has to be remembered that when talking about experiences during the teenage years, the fluctuation is natural and almost anything can provoke adolescents to react negatively. These trends can be seen in the studies on experiences and attitudes towards school in general (e.g. Palomäki \& Heikinaro-Johansson 2011).

\subsection{Conclusions and challenges for future research}

The findings of this study raised several issues that may be worth addressing in the future. Since people are not physically active enough, it is important to find out and analyze in more detail what lies behind this. The findings of this study imply that school PE does not provide everyone with enjoyable experiences and happy memories. How PE is experienced at school is important for the future sport and health behavior of the student him/herself (Trudeau \& Shephard 2005; Yli-Piipari 2011). Therefore, today's schools and the prevailing PE culture are under strong pressure to produce positive student experiences. The school has been given the task of building the student's self-esteem and a positive physical self-concept through favorable PE experiences and of encouraging cooperativeness and positive future sport and health behavior (Finnish National Core Curriculum for Basic Education 2004). These aspects are in line with the international goals of PE (NASPE 2004). However, there continue to be students who do not achieve these goals.

It would be helpful for teachers and teacher educators to be aware of the feelings that PE arouses in order to develop school PE and sport pedagogy and the school PE learning environment so as to benefit all students. PE teachers perform valuable and challenging work with sensitive young people. If today's generation have a different relationship with their bodies (Ylilahti 2013, 107), this challenges PE teachers to find new ways to encourage students to adopt a physically active lifestyle. A closer look at the curriculum and perhaps updating it to respond to the needs of today's students' could increase their dedication to school PE and a physically active lifestyle. Will the ongoing curriculum reform, both in basic education and in teacher education, be able to answer this challenge?

Student's perceived motor competence and physical ability, and received positive feedback are key concepts. Teachers have a prominent role in influencing this (Graham 2008; Rink 2010). Teachers also need to widen their understanding on the powerful role of emotions and experiences, as these can include humiliation and shame. Teachers' sensitivity to students' feelings and 
emotional expressions as well as in handling them requires solid interactional skills (Klemola 2009; Klemola, Heikinaro-Johansson \& O'Sullivan 2013). This needs to be studied and developed further in teacher education. Making greater use of cooperative and group processing learning (Dyson \& Casey 2012) could be one way of shifting the focus away from competitive individual performance to learning by doing together.

Since the data in this study were based on open Internet discussion forum messages, some issues could not be examined. To obtain further insight into this complicated topic a multi-method approach needs to be used in the future.

The findings of this study call for everyone working in school PE to listen to the voices of students. I encourage teachers and teacher educators to now and again check and read what is written in Internet discussion forums. In the future, every opinion that gives a sign of possible withdrawal from a physically active lifestyle should be taken seriously. This is a big task for the future. Messages posted on Internet discussion forums that simultaneously express both positive and negative opinions present teachers, teacher education and curriculum with the challenge of changing negative opinions into positive ones. At the same time, they present us, as educators, with the task of strengthening positive outcomes by offering experiences that at least somehow connect school PE with students' lives. We have to do something to prevent school PE leading to alienation; instead, it should be designed to support engagement in a physically active lifestyle.

The findings of this study indicate the openness that attends describing school PE when doing it behind a screen, anonymously. Thus far, there has not been enough research on discussions in Internet forums on the topic of PE. Listening to the writers' voices in their own natural context outside of a formal research setting can contribute importantly to knowledge in this field. It would seem that a sizeable group of people exists who want and need to be heard, and for whom this is best done through an Internet discussion forum. These results also indicate the existence of a group of people for whom the existing curriculum is unsuited and for whom the main aim of school PE, i.e. promoting a physically active lifestyle, is not realized.

Decisions on PE curriculum reform, in schools and in the contents of teacher education, should reflect the needs and values of today's students. How can a balance be struck between the information overflow and ever-decreasing resources in both universities and schools? The implications of these decisions for the innate human drive to engage in physical activity - to support or discourage it - remain to be seen. 


\section{Post scriptum}

The quotation in the title of this present study continued following

"...winter sports like skating and skiing don't hit the spot...But fortunately the snow melts and we get to play [Finnish] baseball $\vee$

$(10,5,102 /$ data II) 


\title{
YHTEENVETO (FINNISH SUMMARY)
}

\author{
"Yleensä tykkään koululiikunnasta, mutta..." \\ Koululiikunnasta sanottua internetin keskustelupalstoilla
}

Tutkimuksen tarkoitus oli selvittää, millaisena oppilaiden suhtautuminen koululiikuntaan ilmenee internetin avoimilla keskustelupalstoilla. Kysymystä selvitettiin tarkastelemalla sitä, miten oppilaat (tai entiset oppilaat) itse kuvasivat suhdettaan koululiikuntaan internetin avoimille keskustelupalstoille kirjoittamissaan viesteissä. Koululiikunnasta saatujen kokemusten tiedetään vaikuttavan osaltaan henkilön myöhempään liikunta-aktiivisuuteen. Tutkimuksen taustalla olikin huoli siitä, miten myönteisen tai kielteisen kuvan oppilas saa koululiikunnasta. Oppilaan käsitys itsestään liikkujana on yhteydessä hänen fyysiseen aktiivisuuteensa ja liikuntaan asennoitumiseensa. Koulun liikuntakasvatuksen tavoitteena on liikunnallisesti aktiivisen elämäntavan omaksuminen. Se edellyttää myönteistä liikuntasuhdetta. Myönteisen liikuntasuhteen syntymisessä oppilasta ympäröivän kokemusmaailman merkitys on huomattava. Oppilaan sekä ulkopuolelta saamat kokemukset että useat sisäiset tekijät vaikuttavat siihen, millaisen merkityksen hän antaa koululiikunnalle. Aikaisemmissa tutkimuksissa on todettu, että koululiikuntaan suhtaudutaan pääosin myönteisesti, vaikka myös kielteisistä kokemuksista on raportoitu. Nykynuoren elämässä internetillä on keskeinen asema, ja siksi se tarjoaa uuden kanavan kuulla oppilaan ääntä.

Tässä artikkeleista koostuvassa väitöskirjatutkimuksessa kiteytyi kolme suomalaiseen koululiikuntaan liittyvää tutkimustehtävää. Ensimmäisenä tehtävänä oli selvittää, miten kirjoittajat kuvaavat internetin keskustelupalstoilla koululiikuntakokemuksiaan. Toisena tehtävänä selvitettiin, minkälaisia tekijöitä viestien sisältämissä mielipiteissä oli erotettavissa. Kolmanneksi tarkennettiin sitä, mitkä viesteissä mainitut tekijät voivat joko lisätä koululiikuntaan sitoutumista tai vastaavasti vieraannuttaa koululiikunnasta.

Keräsin tutkimuksen aineiston viikolla 15 vuosina 2007 (Data I) ja 2012

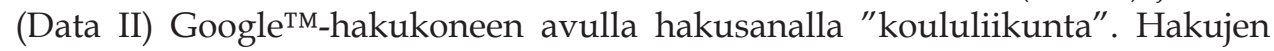
ensimmäiset 200 osumaa käsittivät yhteensä 35 (9/Data I ja 26/Data II) keskustelupalstaa. Keräsin aineiston näiltä kaikille avoimilta keskustelupalstoilta. En manipuloinut keskustelua enkä vaikuttanut siihen, eli koululiikunnasta kirjoitettiin näillä keskustelupalstoilla tästä tutkimuksesta riippumatta. Analysoin keskustelupalstat laadullisen aineiston sisällönanalyysin avulla. Luokittelin palstoilla olleet viestit aluksi myönteisiin, sekä myönteisiin että kielteisiin, kielteisiin viesteihin ja lisäksi ryhmään "muut" viestit. "Muut" viestit -ryhmän jätin myöhemmin tutkimuksen ulkopuolelle, koska sen viestit eivät käsitelleet varsinaista tutkimusaihetta.

Seuraavassa vaiheessa jaottelin mainittujen kolmen ryhmän viestit (Data I) pienempiin osiin: mielipiteisiin/kannanottoihin. Jokainen viesti sisälsi yhden tai useamman mielipiteen. Mielipiteitä luokitellessani kohdistin huomion sisäisiin ja ulkoisiin tekijöihin. Tässä vaiheessa analyysin pohjana käytettyyn Carls- 
sonin (1995) alkuperäisen mallin mukaiseen luokitteluun tarvitsin aineiston käsittelemiseksi lisää luokkia. Sisäisiä tekijöitä kuvaavat luokat muodostin lopulta seuraaviksi: kirjoittajan käsitys omista kyvyistään, tunteiden kirjo, uskomukset koululiikunnasta, välttelyt ja selittelyt. Ulkoisten tekijöiden luokiksi jäsensin vastaavasti seuraavat: opettajan persoonallisuus ja käyttäytyminen, opetussuunnitelma, luokan ilmapiiri, koulun ulkopuoliset tekijät, arviointi, tilat ja välineet. Toisessa aineistossa (Data II) suurimpana ryhmänä olivat alun perin viestit, joiden sisältö oli sekä myönteinen että kielteinen. Nämä viestit ryhmittelin uudelleen kolmen kriteerin mukaisesti: pääosin myönteiset, sekä myönteiset että kielteiset, pääosin kielteiset viestit. Pääosin myönteinen viesti sisälsi jonkin kielteisen lausuman, jonka tarkensin aikaisemmin mainittujen sisäisten ja ulkoisten tekijöiden perusteella. Tein samoin pääosin kielteisen viestin myönteiselle ilmaisulle sekä niille viesteille, jotka sisälsivät useampia sekä myönteisiä että kielteisiä lausumia.

Tulokset osoittivat, että koululiikunnasta kirjoitettiin ensimmäisessä aineistossa vahvoin, kielteisin (64 \%) viestein ja että kirjoittajat esittivät mielipiteitään voimakkaan rajusti. Kielteisissä viesteissä keskeisinä kannanoton kohteina olivat usein opettaja, muut oppilaat, opetussuunnitelma, olosuhteet ja välineet tai kokemukset peseytymistilanteista. Sekä myönteisiä että kielteisiä mielipiteitä edustavia viestejä oli noin neljännes. Nämä viestit olivat selvästi keskenään vastakkaisia ja kuvasivat usein yksittäisiä vahvoja tunnekokemuksia. Täysin myönteisiä viestejä oli ensimmäisessä aineistossa vähiten (12\%). Niiden pääpaino oli yleisesti koululiikunnan piirteissä, ja kokemukset olivat yhteydessä lähinnä kirjoittajan omakohtaisiin myönteisiin tunteisiin. Viisi vuotta myöhemmin kerätyssä aineistossa viestit painottuivat selvästi aikaisempaa aineistoa enemmän kuvaamaan sekä myönteisiä että kielteisiä (49\%) lausumia. Täysin kielteisiä tai täysin myönteisiä viestejä oli tasaisemmin, noin neljännes kumpaakin.

Tarkemmin analysoiduissa koululiikunnasta ilmaistuissa (Data I) mielipiteissä korostuivat ulkoiset tekijät (62 \%). Ulkoisista tekijöistä koostuvat mielipiteet kohdistuivat useimmin (40 \%) opettajan persoonaan ja hänen käyttäytymiseensä. Opettajista kirjoitettiin hyvin lämpimin ja myönteisin sanoin, mutta käytettiin myös varsin voimakkaita kielteisiä ilmaisuja. Opettajan oppilaille antama vastuu (tai sen puuttuminen) heidän tekemisestään, valinnoistaan ja opetettavasta sisällöstä puhututti viesteissä usein. Toiseksi eniten ulkoisista tekijöistä mainittiin luokan ilmapiiri (24\%), josta selvimpänä yksittäisenä aiheena viesteissä kirjoitettiin joukkuejaoista ja niiden herättämistä tunteista. Kolmanneksi eniten ulkoisiin tekijöihin luokitellut mielipiteet liittyivät opetussuunnitelmaan (16\%), jossa eri lajit herättivät paljon keskustelua. Sisäisiin tekijöihin (38 \%) luokitelluista mielipiteistä lähes puolet kuvasi erilaisia tunteita liikuntaa kohtaan ja neljännes käsitteli sitä, millaisiksi kirjoittajat kokivat itsensä liikkujina. Näissä mielipiteissä yleisin oli jokin kielteiseksi koettu tunne, jota kirjoittajat kuvasivat ärsyttäväksi, hävettäväksi tai pelottavaksi. Pelkoa ilmeni varsinkin silloin, kun käsitys omasta liikunnallisuudesta oli heikko. 
Vuonna 2012 kerätyssä aineistossa (Data II) sellaisessa viestissä, joka oli pääosin myönteinen mutta sisälsi jonkin kielteisen tekijän tai päinvastoin eli oli pääosin kielteinen mutta sisälsi jonkin myönteisen tekijän, mielipiteet jakautuivat eniten juuri ulkoisen tekijän (68\%) osalta. Kaikissa viesteissä, jotka sisälsivät sekä myönteisiä että kielteisiä ajatuksia, opetussuunnitelma mainittiin yleisimmin $(35 \%)$ mielipidettä jakavana tekijänä. Sen jälkeen opettaja, luokan ilmapiiri ja erilaiset tunteet liikuntaa kohtaan olivat niitä tekijöitä, joita kirjoittajat kuvasivat muuten myönteisessä viestissä kielteisinä tai vastaavasti muuten kielteisessä viestissä myönteisinä tekijöinä.

Tulosten perusteella liikuntakasvatuksessa on kiinnitettävä entistä enemmän huomiota emotionaalisiin tilanteisiin ja pedagogisiin ratkaisuihin. Tämän tutkimuksen kohteena olleissa viesteissä vastenmielisyys koululiikuntaan näytti syntyvän voimakkaista kielteisiä tunteita herättävistä kokemuksista. Opettajat tekevät arvokasta ja vaativaa työtä sensitiivisten nuorten kanssa. On tärkeää, että opettajat ovat aidosti kiinnostuneita oppilaistaan ja että heillä on monipuolisia keinoja heidän rohkaisemiseensa. Kuuntelemalla oppilaiden mielipiteitä sekä antamalla heille vastuuta ja mahdollisuuksia vaikuttaa omaan työskentelyynsä voidaan luoda parempia edellytyksiä heidän sitouttamisekseen liikuntaan. Oppilaiden näkemyksen mukaan koululiikunnan pitäisi olla mielekästä ja motivoivaa, ei kilpailullista, nöyryyttävää ja pakottavaa. Näyttää siltä, että opettajankoulutuksessa olisi entistäkin enemmän kiinnitettävä huomiota opettajiksi opiskelevien herkkyyteen tunnistaa oppilaiden erilaisuus ja ottaa oppilaiden sensitiivisyys huomioon. Tämä on tulevaisuudessa haasteena sekä opettajankoulutuksessa että jo koulutukseen hakevia valittaessa.

Sekä myönteisiä että kielteisiä mielipiteitä sisältävistä viesteistä muodostuu opettajille vaativa tehtävä, kun he pyrkivät kääntämään niiden taustalla olevat negatiiviset kokemukset positiivisiksi. Jokaisella oppilaalla on oikeus omiin tunteisiinsa. Kokemusten syntyminen on todennäköisesti hyvin tilannesidonnaista. Opettajan olisi saatava luoduksi erilaisuuden ja erilaiset arvot hyväksyvä turvallinen ilmapiiri. Muuten voi olla vaarana, että liikuntakasvatuksessa välittyy sellainen ihmiskuva, jossa ihmisarvo perustuu vain fyysisiin suorituksiin. Oppilaan luottamus itseensä ja luokkakavereihin luo myönteisen ilmapiirin, jossa on tilaa erilaisille tunteille. Nämä seikat vaikuttavat siihen, millaisia päätöksiä yksilö tekee suhteessa liikuntaan. Myös opetussuunnitelma ja opetettavat lajit ja niiden yksi- ja/tai monipuolisuus vaikuttavat siihen, miten oppilas sitoutuu koululiikuntaan tai mahdollisesti siitä vieraantuu.

Nuoren suhdetta liikuntaan voidaan tarkastella laajemmin soveltaen ihmisen ekologista kehittymistä ja sosiaalistumista kuvaavaa Bronfenbrennerin mallia. Sosiaalinen media tarjoaa nuorille uusia mahdollisuuksia omien kokemustensa ja tunteidensa reflektointiin suhteessa ympäröivään todellisuuteen. Osa liikuntasuhdetta muokkaavista vaikutuksista syntyy yhteiskunnan arvostuksista, joita välittävät oppilaalle muun muassa media ja koulun opetussuunnitelma. Opettajan merkitys on olennainen, sillä opettajan välityksellä esimerkiksi yhteiskunnalliset arvostukset ja määritykset kulkeutuvat konkreettisiin opetustilanteisiin. Myöskään koulukavereiden vaikutusta ei pidä unohtaa. Internetin 
osuus nuoren jokapäiväisessä elämässä tuo tähän keskusteluun oman huomiota vaativan lisänsä. Uusia valtakunnallisen opetussuunnitelman tavoitteita muokattaessa on muistettava, että ne vaikuttavat ratkaisevasti tulevien oppilaiden koululiikuntakokemuksiin.

Koska internetillä on tärkeä asema nykynuoren elämässä, internetin keskustelupalstoilta välittyvän oppilaan äänen kuuleminen avaa uudenlaisen näkökulman siihen, millaisen merkityksen oppilas antaa koululiikunnalle. Tässä tutkimuksessa ilmennyt kielteisten viestien painottuminen poikkeaa aikaisempien koululiikuntatutkimusten tuloksista. Kielteisyyden painottuminen voi selittyä menetelmän valinnasta. Tuloksia käsiteltäessä on muistettava, että internetin keskustelupalstoilla käytävä keskustelu antaa mahdollisuuden anonyymiyteen. Kun kirjoittajan henkilöyden voi verkossa "piilottaa" täysin näytön taakse, sensitiivisissä asioissa voi helposti reagoida kokemuksiin pikaisesti ja käyttää voimakkaitakin ilmaisuja. Vahvat tunteet, pettymykset ja kokemukset synnyttävät suuren tarpeen kirjoittaa ja jakaa tuntemuksia muiden kanssa. Siksi näitä tuloksia voidaan peilata ja yleistää vain tutkimusaineistona olleeseen kohdejoukkoon. Lisäksi on muistettava, että tässä tutkimuksessa pääpaino oli koululiikuntaan liittyvien viestien analysoinnissa, ei yksittäisten henkilöiden tasolle menevässä tulkinnassa.

Avainsanat: koululiikunta, internetin keskustelupalsta, viestit 


\section{REFERENCES}

ACSM. 2008. American College of Sports Medicine: ACSM issues new recommendations on quantity and quality of exercise. Retrieved 12 December 2013, from http://www.acsm.org/about-acsm/mediaroom/news-releases/2011/08/01/acsm-issues-new-recommendationson-quantity-and-quality-of-exercise

AHA. 2013. American Heart Association: Recommendations for physical activity in adults. Retrieved 12 December 2013, from http://www.heart.org/HEARTORG/GettingHealthy/PhysicalActivity/ StartWalking/American-Heart-AssociationGuidelines_UCM_307976_Article.jsp Annerstedt, C. 2008. Physical education in Scandinavia with a focus on Sweden: a comparative perspective. Physical Education \& Sport Pedagogy 13 (4), 303-318.

Armour, K. 2010. The physical education profession and its professional responsibility... or ... why '12 weeks paid holiday' will never be enough. Physical Education and Sport Pedagogy 15 (1), 1-13.

Arpo, R. 2005. Internetin keskustelukulttuurit: tutkimus internetkeskusteluryhmien viesteissä rakentuvista puhetavoista, tulkinnoista ja tulkinnan kehyksistä kommunikaatioyhteiskunnassa [Discussion cultures on the Internet. A study of the ways of speaking, interpretations and frames of interpretation constructed in the messages of Internet discussion groups in a communication society]. Publications in the Humanities 39. University of Joensuu.

Asanti, R. 2013. Liikuntapedagogiikka osana koulun toimintakulttuuria. In T. Jaakkola, J. Liukkonen and A. Sääkslahti (Eds.), Liikuntapedagogiikka. Jyväskylä: PS-kustannus, 620-636.

Azzarito, L., Solmon, M. A. \& Harrison, L. 2006. “...If I had a choice, I would...” A feminist poststructuralist perspective on girls in physical education. Research Quarterly for Exercise and Sport 77 (2), 222-239.

Bailey, R. 2006. Physical education and sport in schools: a review of benefits and outcomes. Journal of School Health 76 (8), 397-401.

Bailey, R., Armour, K., Kirk, D., Jess, M., Pickup, I. \& Standford, R., and the BERA. 2009. The educational benefits claimed for physical education and school sport: an academic review. Research Papers in Education 24 (1), 126.

Barkoukis, V. 2007. Experience of state anxiety in physical education. In J. Liukkonen, Y. V. Auweele, B. Vereijken, D. Alfermann \& Y. Theodorakis (Eds.), Psychology for physical educators. 2. ed. Champaign, IL: Human Kinetics, 57-72.

Basic Education Act 1998. Available: http://www.finlex.fi/en/laki/kaannokset/1998/ en19980628

Bassett, E. H. \& O'Riordan, K. 2002. Ethics of Internet research: contesting the human subjects research model. Ethics and Information Technology 4 (3), 233-247. 
Berg, P. 2010. Ryhmärajoja ja hierarkioita: etnografinen tutkimus peruskoulun yläasteen liikunnanopetuksesta. [Group boundaries and hierarchies: Ethnographic study of physical education in secondary school]. Social Psychological Studies 22. University of Helsinki.

Bernstein, E., Phillips, S. R. \& Silverman, S. 2011. Attitudes and perceptions of middle school students toward competitive activities in physical education. Journal of Teaching in Physical Education 30 (1), 69-83.

Bevans, K., Fitzpatrick, L.-A., Sanchez, S. \& Forrest, C. 2010. Physical education resources, class management, and student physical activity levels: a structure-process-outcome approach to evaluating physical education effectiveness. Journal of School Health 80 (12), 573-580.

Biddle, S. \& Mutrie, N. 2007. Psychology of physical activity: determinants, well-being, and interventions. 2nd ed. London: Routledge.

Biddle, S., Wang, C., Chatzisarantis, N. \& Spray, C. 2003. Motivation for physical activity in young people: entity and incremental beliefs about athletic ability. Journal of Sport Sciences 21 (12), 973-989.

Blankeship, B. T. \& Ayers, S. F. 2010. The role of PETE in developing joyoriented physical educators. Quest 62 (2), 171-183.

Bonsdorff, M. von \& Rantanen, T. 2011. Progression of functional limitations in relation to physical activity: a life course approach. European Review of Aging and Physical Activity 8 (1), 23-30.

Braun, V. \& Clarke, V. 2006. Using thematic analysis in psychology. Qualitative Research in Psychology 3 (2), 77-101.

Bronfenbrenner, U. 1979. The ecology of human development: experiments by nature and design. Cambridge, MA: Harvard University Press.

Bronfenbrenner, U. 1989. Ecological systems theory. In R. Vasta (Ed.), Annals of child development: Vol. 6. Six theories of child development: Revised formulations and current issues. JAI Press: London, 187-249.

Bronfenbrenner, U. 1994. Ecologial models of human development. International Encyclopedia of Education, vol 3, $2^{\text {nd }}$ ed. Oxford: Elsevier. Reprinted in: Gauvain, M \& Cole, M. (Eds.) 1993. Readings on the development of children, $2^{\text {nd }}$ ed. NY: Freeman, 37-43.

Broom, A. 2005. The eMale prostate cancer, masculinity and online support as a challenge to medical expertise. Journal of Sociology 41 (1), 87-104. doi: $10.1177 / 1440783305050965$

Brown, G., Maycock, B. \& Burns, S. 2005. Your picture is your bait: use and meaning of cyberspace among gay men. Journal of Sex Research 42 (1), 6373.

Bruckman, A. 2002. Studying the amateur artist: a perspective on disguising data collected in human subjects research on the Internet. Ethics and Information Technology 4 (3), 217-231.

Bruner, J. S. 1987. Life as narrative. Social Research 54 (1), 11-32.

Bunker, D. \& Thorpe, R. 1982. A model for the teaching of games in secondary schools. Bulletin of Physical Education 18 (1), 5-8. 
Carlson, T. 1995. We hate gym: student alienation from physical education. Journal of Teaching in Physical Education 14 (4), 467-477.

Carroll, B. \& Loumidis, J. 2001. Children's perceived competence and enjoyment in physical education and physical activity outside school. European Physical Education Review 7 (1), 24-43.

Clark, J. E. 2007. On the problem of motor skill development. Journal of Physical Education, Recreation \& Dance 78 (5), 39-44.

Constantinou, P., Manson, M. \& Silverman, S. 2009. Female students' perceptions about gender-role stereotypes and their influence on attitude toward physical education. Physical Educator 66 (2), 85-96.

Cothran, D. 2010. Students' curricular values and experiences. In M. O'Sullivan and A. MacPhail (Eds.), Young people's voices in physical education and youth sport. London: Routledge, 49-62.

Cothran, D. J. \& Ennis, C. D. 1997. Students' and teachers' perceptions of conflict and power. Teaching and Teacher Education 13 (5), 541-553.

Cothran, D. J. \& Kulinna, P. H. 2007. Students' reports of misbehavior in physical education. Research Quarterly for Exercise and Sport 78 (3), 216224.

Coulter, M. \& Chróinín, D. N. 2011. What is PE? Sport, Education and Society iFirst article, 1-17.

Coulter, M. \& Woods, C. B. 2011. An exploration of children's perceptions and enjoyment of school-based physical activity and physical education. Journal of Physical Activity and Health 8 (5), 645-654.

Couturier, L. E., Chepko, S. \& Coughlin, M. A. 2005. Student voices - what middle and high school students have to say about physical education. Physical Educator 62 (4), 170-178.

Council of Europe. 2012. Young people combating hate speech online. Available: http://www.coe.int/t/dg4/youth/news/2012_young_bloggers_combat_ hate_speech_EN.

Dismore, H. \& Bailey, R. 2010. 'It has been a bit of a rocky start': attitudes towards physical education following transition. Physical Education \& Sport Pedagogy 15 (2), 175-191.

Drentea, P. \& Moren-Cross, J. L. 2005. Social capital and social support on the web: the case of an Internet mother site. Sociology of Health \& Illness 27 (7), 920-943.

Dyson, B. 2006. Students' perspectives of physical education. In D. Kirk, D. Macdonald and M. O'Sullivan (Eds.), The handbook of physical education. London: Sage, 326-346.

Dyson, B. \& Casey, A. (Eds.) 2012. Cooperative Learning in Physical Education: A research based approach. London, UK: Routledge.

Ennis, C. D. 2013. Implementing meaningful, educative curricula, and assessments in complex school environments. Sport, Education and Society $18(1), 115-120$. 
Enright, E. \& O'Sullivan, M. 2013. "Now, I'm magazine detective the whole time": listening and responding to young people's complex experiences of popular physical culture. Journal of Teaching in Physical Education 32 (4), 394-418.

Eriksson, I. 2013. Tukea vai ilkeilyä verkkokeskustelupalstalla? Aikuiskasvatus 3, 190-200.

European Commission/EACEA/Eurydice, 2013. Physical education and sport at school in Europe. Eurydice Report. Luxemburg: Publications Offline in the European Union.

Evans, J., Davies, B. \& Rich, E. 2009. The body made flesh: embodied learning and the corporeal device. British Journal of Sociology of Education 30 (4), 391-406.

Ferry, M. \& McCaughtry, N. 2013. secondary physical educators and sport content: a love affair. Journal of Teaching in Physical Education 32 (4), 375-393.

Ferry, M., McCaughtry, N. \& Hodges Kulinna, P. 2011. Social and emotional pedagogy: rhythm and junctures. Journal of Teaching in Physical Education 30 (1), 13-30.

Finnish Advisory Board on Research Integrity. 2012. Responsible conduct of research and procedures for handling allegations of misconduct in Finland - RCR guidelines [accessed 10 January 2014] Available: http://www.tenk.fi/en/resposible-conduct-research-guidelines.

Finnish National Board of Education. 2013. Teacher education. Available: http://www.oph.fi/english/education_system/teacher_education

Finnish National Board of Education. 2013. OPS 2016 - Renewal of the core curriculum for pre-primary and basic education [accessed 10 January 2014]. Available: http://www.oph.fi/english/current_issues/101/0/ ops2016_renewal_of_the_core_curriculum_for_pre-primary_and_basic_education

Finnish National Core Curriculum for Basic Education. 2004. [accessed 28 January 2014]. Available: http://www.oph.fi/english.

Fisette, J. L. 2013. 'Are you listening?': adolescent girls voice how they negotiate self-identified barriers to their success and survival in physical education. Physical Education and Sport Pedagogy 18 (2), 184-203.

Flintoff, A. \& Scranton, S. 2001. Stepping into active leisure? Young women's perceptions of active lifestyles and their experiences of school physical education. Sport, Education and Society 6 (1), 5-21.

Flory, S. B. \& McCaughtry, N. 2011. Culturally relevant physical education in urban schools: reflecting cultural knowledge. Research Quarterly for Exercise and Sport 82 (1), 49-60.

Fox, K. R. 1997. The physical self and processes in self-esteem development. In K. R. Fox (Ed.), The physical self: from motivation to well-being Champaign, IL: Human Kinetics, 111-139. 
Fox, K. R. 1998. Lapsen näkökulmia liikunnassa: liikuntakasvatuksen psykologinen ulottuvuus. In E.-L. Sarlin, H. Sarlin, T. Lintunen, J. Liukkonen and A. Pönkkö (Eds.), Motivaatio ja minäkäsitys liikunnassa ja urheilussa. Vuokatin liikuntapsykologinen seminaari. Oulun yliopisto. Kajaanin opettajankoulutuslaitoksen julkaisuja B: 10, 1-3.

Fox, K. R. 2000. The effects of exercise on self-perceptions and self-esteem. In S. J. H. Biddle, K. R. Fox and S. H. Boutcher (Eds.), Physical activity and psychological well-being. London: Routledge, 88-117.

Fox, K. R. \& Corbin, C. B. 1989. The physical self-perception profile: development and preliminary validation. Journal of Sport \& Exercise Psychology 4, 408-430.

Gallahue, D. \& Cleland-Donnelly, F. 2007. Developmental physical education for all children. Champaign, IL: Human Kinetics.

Gallahue, D., Ozmun, J. \& Goodway, J. 2012. Understanding motor development: infants, children, adolescents, adults. New York : McGrawHill.

Garn, A. C. \& Cothran, D. J. 2006. The fun factor in physical education. Journal of Teaching in Physical Education 25 (3), 281-297.

Gibbons, S. L. \& Humbert, L. 2008. What are middle-school girls looking for in physical education? Canadian Journal of Education 31 (1), 167-186.

Graffigna, G., Bosio, A. C. \& Olson, K. 2008. Face-to-face vs. online focus groups in two different countries: do qualitative data collection strategies work the same way in different cultural contexts? In P. Liamputtong (Ed.), Doing cross-cultural research: ethical and methodological perspectives. London: Springer, 265-286.

Graham, G. 2008. Teaching children physical education. Becoming a master teacher. Champaign, IL: Human Kinetics.

Graham, T. \& Wright, S. 2013. Discursive equality and everyday talk online: the impact of "superparticipants". Journal of Computer-Mediated Communication, published online 20 May 2013, doi: 10.1111/jcc4.12016

Grisso, A. D. \& Weiss, D. 2005. What are gURLs talking about? Adolescent girls' construction of sexual identity on gURL.com. In S. R. Mazzarella (Ed.), Girl wide web: girls, the Internet, and the negotiation of identity. New York: Peter Lang, 31-49.

Groves, S. \& Laws, C. 2000. Children's experiences of physical education. European Journal of Physical Education 5 (1), 19-27.

Haerens, L., Aelterman, N., Van den Berghe, L., De Meyer, J., Soenens, B. \& Vansteenkiste, M. 2013. Observing physical education teachers' need supportive interactions in classroom settings. Journal of Sport \& Exercise Psychology 35 (1), 3-17.

Hagger, M., Wood, C., Stiff, C. \& Chatzisarantis, N. 2009. The strength model of self regulation failure and health-related behaviour. Health Psychology Review 3 (2), 208-238. 
Halas, J. 2002. engaging alienated youth in physical education: an alternative program with lessons for the traditional class. Journal of Teaching in Physical Education 21 (3), 267-286.

Ham, S. A., Kruger, J. \& Tudor-Locke, C. 2009. Participation by US adults in sports, exercise, and recreational physical activities. Journal of Physical Activity and Health 6 (1), 6-14.

Hartmann, T., Zahner, L., Pühse, U., Schneider, S., Puder, J. \& Kriemler, S. 2009. Physical activity, bodyweight, health and fear of negative evaluation in primary school children. Scandinavian Journal of Medicine and Science in Sports e27-e34.

Hassmén, P., Koivula, N. \& Uutela, A. 2000. Physical exercise and psychological well-being: a population study in Finland. Preventive Medicine 30 (1), 1725.

Heikinaro-Johansson, P. 1995. Including students with special needs in physical eduation. Studies in Sport, Physical Education and Health 39. University of Jyväskylä.

Heikinaro-Johansson, P. \& Telama, R. 2005. Physical education in Finland. In U. Pühse and M. Gerber (Eds.), International comparison of physical education. Oxford, UK: Meyer \& Meyer Sport, 250-271.

Hersberger, J. A., Murray, A. L. \& Rioux, K. S. 2007. Examining information exchange and virtual communities: an emergent framework. Online Information Review 31 (2), 135-147.

Hine, C. 2000. Virtual ethnography. London: Sage.

Information and communication technology strategy of the Finnish teacher training schools consortium 2013-2016.

Available: http:/ / www.enorssi.fi/ tvt-ja-opetus/tvt-strategiat1/

The_Information_and_Communication_Technology_Strategy_06032013.pdf

Jaakkola, T., Liukkonen, J. \& Sääkslahti, A. 2013. Johdatus liikuntapedagogiikkaan. In T. Jaakkola, J. Liukkonen and A. Sääkslahti (Eds.), Liikuntapedagogiikka. Jyväskylä: PS-kustannus, 17-27.

Johansson, N., Heikinaro-Johansson, P. \& Palomäki, S. 2011. Kohtaavatko peruskoulun opetussuunnitelman tavoitteet ja oppilaiden kiinnostus liikunnanopetuksessa? In S. Laitinen and A. Hilmola (Eds.), Taito- ja taideaineiden oppimistulokset: asiantuntijoiden arviointia. Helsinki: Opetushallitus, 237-248.

Kalaja, S. 2012. Fundamental movement skills, physical activity, and motivation toward Finnish school physical education: a fundamental movement skills intervention. [Perusliikuntataidot, fyysinen aktiivisuus ja motivaatiotekijät koululiikuntaa kohtaan: perusliikuntataitointerventio]. Studies in Sport, Physical Education and Health 183. University of Jyväskylä.

Kalaja, T. 2012. Liikunnan aineenopettajakoulutuksen opiskelijavalinnat muutoksessa [Student selection of physical education teacher program in the state of change]. Studies in Sport, Physical Education and Health 181. University of Jyväskylä. 
Kangasniemi, J. 2008. Yksinäisyyden kokemisen avainkomponentit Yleisradion tekstitelevision Nuorten palstan kirjoituksissa [The key components of the experience of loneliness on the Finnish Broadcasting Company's (YLE) teletext forum for adolecents]. Studies of Humanities 107. University of Jyväskylä.

Kantomaa, M. 2010. The role of physical activity on emotional and behavioural problems, self-rated health and educational attainment among adolescents. Acta Universitatis Ouluensis, D Medica 1043. University of Oulu.

Kauravaara, K. 2013. Mitä sitten, jos ei liikuta? Etnografinen tutkimus nuorista miehistä. Liikunnan ja kansanterveyden julkaisuja 276. University of Jyväskylä.

Kenway, J. \& Bullen, E. 2001. Consuming children. Education - entertainment advertising. Maidenhead: Open University Press.

King, S. 1996. Researching Internet communities: proposed ethical guidelines for the reporting of the results. The Information Society 12 (2), 119-127.

Kirk, D. 2005. Physical education, youth sport and lifelong participation: the importance of early learning experiences. European Physical Education Review 11 (3), 239-255.

Kirk, D., Macdonald, D. \& O'Sullivan 2006. Introduction. In D. Kirk, D. Macdonald and M. O'Sullivan (Eds.), The handbook of physical education. London: Sage, $x$.

Klemola, U. 2009. Opettajaksi opiskelevien vuorovaikutustaitojen kehittäminen liikunnan aineenopettajakoulutuksessa [Developing student teachers' social interaction skills in physical education teacher education]. Studies in Sport, Physical Education and Health 139. University of Jyväskylä.

Klemola, U., Heikinaro-Johansson, P. \& O'Sullivan, M. 2013. Physical education student teachers' perceptions of applying knowledge and skills about emotional understanding in PETE in a one-year teaching practicum. Physical Education and Sport Pedagogy 18 (1), 28-41.

Kontoniemi, M. \& Salo, O.-P. (Eds.) 2011. Educating teachers in the PISA paradise. Perspectives on teacher education at a Finnish university. Jyväskylä Teacher Training School 12, University of Jyväskylä.

Koski, K. \& Pollari, P. 2011. Teacher training schools - the Finnish way of organizing teacher training. In M. Kontoniemi, \& O.-P. Salo (Eds.), Educating teachers in the PISA paradise. Perspectives on teacher education at a Finnish university. Jyväskylä Teacher Training School 12, University of Jyväskylä, 13-18.

Kosonen, U. 1998. Koulumuistoja naiseksi kasvamisesta. Yhteiskuntatieteiden, valtio-opin ja filosofian julkaisuja 21. Jyväskylän yliopisto: Sophi.

Kretchmar, R. S. 2008. The increasing utility of elementary school physical education: a mixed blessing and unique challenge. The Elementary School Journal 108 (3), 161-170. 
Kuusela, M. 2005. Sosioemotionaalisten taitojen harjaannuttaminen, oppiminen ja käyttäminen perusopetuksen kahdeksannen luokan tyttöjen liikuntatunneilla. Liikunnan ja kansanterveyden julkaisuja 165. Jyväskylä: LIKES.

Kytölä, S. 2013. Multilingual language use and metapragmatic reflexivity in Finnish internet football forums: a study in the sociolinguistics of globalization. Jyväskylä studies in humanities 200. University of Jyväskylä.

Laakso, L., Telama, R., Nupponen, H., Rimpelä, A. \& Pere, L. 2008. Trends in leisure time physical activity among young people in Finland, 1977-2007. European Physical Education Review 14 (2), 139-155.

Laukkanen, M. 2007. Sähköinen seksuaalisuus: tutkimus tyttöydestä nettikeskusteluissa. Acta Electronica Universitatis Lappoensis 4. Rovaniemi.

Lee, J. 2010. Students' envolving meanings and experiences with physical activity. In M. Sullivan and A. MacPhail (Eds.), Young people's voices in physical education and sport. London: Routledge, 11-30.

Lietsala, K. \& Sirkkunen, E. 2008. Social media. Introduction to the tools and processes of participatory economy. Hypermedia Laboratory Net Series 17. University of Tampere.

Liikkuva koulu [Finnish Schools on the Move]. Available: http://www.liikkuvakoulu.fi/in-english

Lincoln, Y. S. \& Guba, E. G. 1985. Naturalistic inquiry. Newbury Park: Sage.

Lintunen, T. \& Gould, D. 2013. Developing social and emotional skills. In A. Papaioannou and D. Hackfort (Eds.), fundamental concepts in sport and exercise psychology. London: Routledge. Chapter 43, (in press)

Lintunen, T. \& Kuusela, M. 2007. Social and emotional learning in physical education. In J. Liukkonen, Y. Vanden Auweele, W. Vereijken, D. Alfermann, \& Y. Theodorakis. (Eds.), Psychology for physical educators. Champaign, IL: Human Kinetics, 75-83.

Liukkonen, J., Barkoukis, V., Watt, A. \& Jaakkola, T. 2010. Motivational climate and students' emotional experiences and effort in physical education. The Journal of Educational Research 103 (5), 295-308.

Liukkonen, J., Vanden Auweele, Y., Vereijken, B., Alfermann, D. \& Theodorakis, Y. (Eds.), 2007. Psychology for physical educators. 2nd ed, Champaign, IL: Human Kinetics.

Louhela, V. 2012. Kuulluksi tulemisen pedagogiikka kaikille yhteisessä koululiikunnassa [The pedagogy of being heard in inclusive physical education]. Acta Universitatis Ouluensis, E Scientiae Rerum Socialium 130. University of Oulu.

Lubans, D. R., Morgan, P. J., Cliff, D. P., Barnett, L. M. \& Okely, A. D. 2010. Fundamental movement skills in children and adolescents: review of associated health benefits. Sports Medicine 40 (12), 1019-1035. 
Lyyra, N. 2013. Koululiikunnan pedagogiset ulottuvuudet -mittarin validiteetin ja reliabiliteetin tarkastelu konfirmatoristen faktorimallien avulla. [Pedagogical dimensions in physical education inventory: evaluating reliability and validity by using confirmatory factor analysis.] Studies in Sport, Physical Education and Health 198. University of Jyväskylä.

Markham, A. N. 1998. Life online. Researching real experience in virtual space. Walnut Creek, CA: AltaMira.

Markham, A. N. 2007. The Internet as research context. In C. Seale, G. Gobo, J. Gubrium and D. Silverman (Eds.), Qualitative research practice. London: Sage, 328-344.

Mays Woods, A., Bolton, K. N., Graber, K. C. \& Grull, G. S. 2007. Influences of perceived motor competence and motives on children's physical activity. Journal of Teaching in Physical Education 26 (4), 390-403.

McKenzie, T. 2007. The preparation of physical educators: a public health perspective. Quest 59 (4), 346-357.

McKenzie, T. L. \& Lounsbery, M. A. F. 2009. School physical education: the pill not taken. American Journal of Lifestyle Medicine 3 (3), 219-225.

Metzler, M. W., McKenzie, T. L., van der Mars, H., Barrett-Williams, S. L. \& Ellis, R. 2013. Health optimizing physical education (HOPE): a new curriculum for school programs. Part 1: Establising the need and describing the model. JOPERD 84 (4), 41-47.

Millard, W. B. 1997. I flamed Freud. A case study in teletextual incendiarism. In D. Porter (Ed.), Internet culture. New York: Routledge, 145-159.

Moreno, M. A., Frost, N. C. \& Christakis, D. A. 2008. Research ethics in the MySpace era. Pediatrics 121 (1), 157-161.

Morgan, P. \& Hansen, V. 2008. The relationship between PE biographies and PE teaching practices of classroom teachers. Sport, Education and Society 13 (4), 373-391.

Mäkelä, K. \& Huhtiniemi, M. 2011. Teaching practice in physical education at the university of Jyväskylä teacher training school. In M. Kontoniemi, \& O.-P. Salo (Eds.), Educating teachers in the PISA paradise. Perspectives on teacher education at a Finnish university. Jyväskylä Teacher Training School 12, University of Jyväskylä, 123-129.

National association for sport and physical education (NASPE). Moving into the future: national standards for physical education 2004. Reston: NASPE.

Niemi-Pynttäri, R. 2007. Verkkoproosa: tutkimus dialogisesta kirjoittamisesta. Helsinki: ntamo.

Nissinen, K. \& Välijärvi, J. 2011. Opettaja- ja opettajankoulutustarpeiden ennakoinnin tuloksia. Koulutuksen tutkimuslaitos 43. Jyväskylän yliopisto.

Nupponen, H., Penttinen, S., Pehkonen, M., Kalari, J. \& Palosaari, A.-M. 2010. Koululiikunnan vaikuttavuustutkimus: lähtökohdat, menetelmät ja aineiston kuvaus. Turun yliopisto. Opettajankoulutuslaitos. Rauman yksikkö. 
Nurmi, A.-M. 2012. Kaduilta liikuntasaliin. Toimintatutkimus hiphop-tanssista osana lukion liikuntakasvatusta [From street to gym class. Action research on hip hop dance as part of physical education in high school]. Studies in Sport, Physical Education and Health 184. University of Jyväskylä.

Oblinger, D. \& Oblinger, J. (Eds.) 2005. Educating the net generation. EDUCAUSE. Available: www.educause.edu/educatingthenetgen/

Olafson, L. 2002. "I hate Phys. Ed.": adolescent girls talk about physical education. Physical Educator 59 (2), 67-74.

Oliver, K. L. 2010. The body, physical activity and inequity. In M. O'Sullivan and A. MacPhail (Eds.), Young people's voices in physical education and youth sport. London: Routledge, 31-48.

O'Sullivan, M. \& MacPhail, A. 2010. Introduction: re-visioning young people's voices in physical education and sport. In M. O'Sullivan and A. MacPhail (Eds.), Young people's voices in physical education and youth sport. London: Routledge, 1.

Owens, L. \& Ennis, C. 2005. The ethic of care in teaching: an overview of supporting literature. Quest 57 (4), 392-425.

Palomäki, S. \& Heikinaro-Johansson, P. 2011. Liikunnan oppimistulosten seuranta-arviointi perusopetuksessa 2010 [A follow up evaluation of physical education learning outcomes]. Helsinki: Opetushallitus.

Patton, M. 2002. Qualitative research \& evaluation methods. Thousand Oaks, CA: Sage.

Penttinen, S. 2003. Lähtökohdat liikuntaa opettavaksi luokanopettajaksi. Nuoruuden kasvuympäristöt ja opettajankoulutus opettajuuden kehitystekijöinä [Starting points for a primary school physical education teacher. The growth environment of adolecence and teacher education as developmental factors of teachership]. Jyväskylä Studies in Education, Psychology and Social Research 219. University of Jyväskylä.

Phillips, S. R. 2011. Upper elementary school students' attitudes and perceptions toward physical education. Columbia University, ProQuest/UMI Dissertations.

Physical Activity Guidelines Advisory Committee. 2008. Physical activity guidelines advisory committee report, 2008. Washington, DC: Department of Health and Human Services.

Pietilä, M. \& Koivula, P. 2013. Valtakunnalliset opetussuunnitelman perusteet. In T. Jaakkola, J. Liukkonen and A. Sääkslahti (Eds.), Liikuntapedagogiikka. Jyväskylä: PS-kustannus, 274-287.

Pitts, V. 2004. Illness and Internet empowerment: writing and reading breast cancer in cyberspace. Health 8 (1), 33-59.

Portman, P. A. 2003. Are physical education classes encouraging students to be physically active?: experiences of ninth graders in their last semester of required physical education. Physical Educator 60 (3), 150-161. 
Pratt, M., Sarmiento, O. L., Montes, F., Ogilvie, D., Marcus, B. H., Perez, L. G. \& Brownson, R. C. 2012. The implications of megatrends in information and communication technology and transportation for changes in global physical activity. Lancet 380 (9838), 282-293.

Pulkkinen, S. 2011. Valmentajataustan merkitys rehtorin työssä. [The significance of coaching backgound in principal's work]. Jyväskylä Studies in Education, Psychology and Social Research 407. University of Jyväskylä.

Pühse, O. \& Gerber, M. (Eds.) 2005. International comparison of physical education. Oxford, UK: Meyer \& Meyer Sport.

Quay, J. \& Peters, J. 2008. Skills, strategies, sport, and social responsibility: reconnecting physical education. Journal of Curriculum Studies 40 (5), 601-626.

Ransom, D. C., La Guardia, J. G., Woody, E. Z. \& Boyd, J. L. 2010. Interpersonal interactions on online forums addressing eating concerns. International Journal of Eating Disorders 43 (2), 161-170.

Rantanen, T. 2013a. Midlife fitness predicts less burden of chronic disease in later life. Clinical Journal of Sport Medicine (Official journal of the Canadian Academy of Sport and Exersice Medicine) 23 (6), 499-500.

Rantanen, T. 2013b. Promoting mobility in older people. Journal of Preventive Medicine \& Public Health 2 (46), S50-S54.

Rees, R., Kavanagh, J., Harden, A., Shepherd, J., Brunton, G., Oliver, S. \& Oakley, A. 2006. Young people and physical activity: a systematic review matching their views to effective interventions. Health Education Research 21 (6), 806-825.

Rich, E. \& Miah, A. 2009. Prosthetic surveillance: the medical governance of healthy bodies in cyberspace. Surveillance \& Society 6 (2), 163-177.

Rikard, G. L. \& Banville, D. 2006. High school students' attitudes about physical education. Sport, Education and Society 11 (4), 385-400.

Rink, J. 2010. Teaching physical education for learning. New York: McCrawHill.

Rovio, S. 2008. The effect of physical activity and other lifestyle factors on dementia, Alzheimer's disease and structural brain changes. Stockholm: Karolinska Institutet.

Ryen, A. 2007. Ethical issues. In C. Seale, G. Gobo, J. F. Gubrium and D. Silverman (Eds.), Qualitative research practice. London: Sage, 218-235.

Sahlberg, P. 2007. Education policies for raising student learning: the Finnish approach. Journal of Education Policy 22 (2), 147-171.

Sahlberg, P. 2010. The secret to Finland's success: education teachers.

Retrieved 17 June, 2013, from http:/ / edpolicy.stanford.edu/ sites/default/ files/publications/secret-finland $\%$ E2 $\% 80 \% 99$ s-successeducating-teachers.pdf

Salasuo, M. 2012. Uljas uusi maailma? Liikunta ja Tiede 49 (4), 4-11. 
Sallis, J. F., McKenzie, T. L., Beets, M. W., Beighle, A., Erwin, H. \& Lee, S. 2012. Physical education's role in public health: steps forward and backward over 20 years and HOPE for the future. Research Quarterly for Exercise and Sport $8(2), 125-135$.

Seale, C., Charteris-Black, J., MacFarlane, A. \& McPherson, A. 2010. Interviews and Internet forums: a comparison of two sources of qualitative data. Qualitative Health Research 20 (5), 595-606.

Shen, B., McCaughtry, N., Martin, J., Fahlman, M. \& Garn, A. 2012. Urban highschool girls' sense of relatedness and their engagement in physical education. Journal of Teaching in Physical Education 31 (3), 231-245.

Siedentop, D. 1994. Sport education: quality PE through positive sport experiences. Champaign, IL: Human Kinetics.

Siedentop, D. 2002. Content knowledge for physical education. Journal of Teaching in Physical Education 21 (4), 368-377.

Siljamäki, M. 2013. "Kulttuurinen kiinnostus heräsi tanssiharrastukseni myötä". Flamenco, itämainen tanssi ja länsiafrikkalaiset tanssit tanssinopettajien ja -harrastajien kokemana. ["My interest in cultures awoke through dancing". Flamenco, oriental dance and West African dances as experienced by dance teachers and recreational dancers.] Studies in Sport, Physical Education and Health 199. University of Jyväskylä.

Sollerhed, A. C., Ejlertsson, G. \& Apitzsch, E. 2005. Predictors of strong sense of coherence and positive attitudes to physical education in adolescents. Scandinavian Journal of Public Health 33 (5), 334-342.

Spencer-Cavaliere, N. \& Rintoul, M. A. 2012. Alienation in physical education from the perspective of children. Journal of Teaching in Physical Education 31 (4), 344-361.

Statistics Finland. 2007 / 2012 / 2013 Available: https:/ /www.tilastokeskus.fi/ til/ttt_en.html

Stiller, J. \& Alfermann, D. 2007. Promotion of a healthy self-concept. In J. Liukkonen, Y. V. Auweele, B. Vereijken, D. Alfermann and Y. Theodorakis (Eds), Psychology for physical educators. 2. ed. Champaign, IL: Human Kinetics, 123-140.

Stodden, D. F., Goodway, J. D., Langendorfer, S. J., Robertson, M. A., Rudisill, M. E., Garcia, C. \& Garcia, L. E. 2008. A developmental perspective on the role of motor skill competence in physical activity: an emergent relationship. Quest 60 (2), 290-306.

Strean, W. B. 2009. Remembering instructors: play, pain and pedagogy. Qualitative Research in Sport and Exercise 1 (3), 210-220.

Strong, W. B., Malina, R. M., Blimkie, J. R., Daniels, S. R., Dishman, R. K., Gutin, B., Hergenroeder, A. C., Must, A., Nixon, P. A., Pivarnik, J. M., Rowland, T., Trost, S. \& Trudeau, F. 2005. Physical activity recommendations for school-age youth. The Journal of Pediatrics 146 (6), 732-737.

Subramaniam, P. R. \& Silverman, S. 2007. Middle school students' attitudes towards physical education. Teaching and Teacher Education 23 (5), 602-611. 
Sääkslahti, A. 2012. Liikunnanopetuksen perusteet 3-4 -luokille. In A. Sääkslahti, J. Hakamäki, E. Holopainen, T. Laakso, H. Lemmetty, S. Luukkonen, S. Paukku \& J. Puttonen (Eds.), Kirja liikunnasta 3-4. Helsinki: Sanoma Pro, 5-19.

Tammelin, T., Ekelund, U., Remes, J. \& Nayha, S. 2007. Physical activity and sedentary behaviors among Finnish youth. Medicine \& Science in Sports \& Exercise 39 (7), 1067-1074.

Tammelin, T., Laine, K. \& Turpeinen, S. (Eds.) 2013. Oppilaiden fyysinen aktiivisuus. [Physical activity of school-aged children] Liikunnan ja kansanterveyden julkaisuja 272. Jyväskylä: LIKES.

Tapscott, D. 2009. Grown up digital: how the net generation is changing your world. New York: McGraw-Hill.

Tepper, M. 1997. Usenet communities and the cultural politics of information. In D. Porter (Ed.), Internet culture. New York: Routledge, 39-54.

The Global Gender Gap Report 2013. World economic forum. Available: http:// www.weforum.org/reports/global-gender-gap-report-2013

Tischler, A. \& McCaughtry, N. 2011. PE is not for me: when boys' masculinities are threatened. Research Quarterly for Exercise and Sport 82 (1), 37-48.

Tuomi, J. \& Sarajärvi, A. 2009. Laadullinen tutkimus ja sisällönanalyysi. [Qualitative research and content analysis.] Helsinki: Tammi.

Tremblay, M. S., LeBlanc, A. G., Kho, M. E., Saunders, T. J., Larouche, R., Colley, R. C., Goldfield, G. \& Connor Gorber, S. 2011. Systematic review of sedentary behaviour and health indicators in school-aged children and youth. International Journal of Behavioral Nutrition and Physical Activity 8:98.

Trout, J. \& Graber, K. 2009. Perceptions of overweight students concerning their experiences in physical education. Journal of Teaching in Physical Education 28 (3), 272-292.

Trudeau, F. \& Shephard, R. J. 2005. Contribution of school programmes to physical activity levels and attitudes in children and adults. Sport Medicine 35 (2), 89-105.

University of Jyväskylä. 2014. Study with us. Available: https://www.jyu.fi/ en/studywithus

VAKAVA [valtakunnallinen kasvatusalan valintayhteistyöverkosto, national selection cooperation network in the field of education]. Available: http://www.helsinki.fi/vakava/english

van den Berg, T. I. J., Elders, L. A. M., de Zwart, B. C. H. \& Burdorf, A. 2009. The effects of work-related and individual factors on the work ability index: a systematic review. Occupational \& Environmental Medicine 66 (4), 211-220. doi:10.1136/oem.2008.039883

van Oostrom, S. H., Smit, H. A., Wendel-Vos, G. C., Visser, M., Verschuren, W. M. \& Picavet, H. S. 2012. Adopting an active lifestyle during adulthood and health-related quality of life: the Doetinchem Cohort Study. American Journal of Public Health 102 (11), e62-e68. doi: 10.2105/ AJPH.2012.301008. 
Välijärvi, J., Linnakylä, P., Kupari, P., Reinikainen, P., Sulkunen, S., Törnroos, J. \& Arffman, I. 2007. The Finnish success in PISA - and some reasons behind it 2. PISA 2003. Institute for Educational Research. University of Jyväskylä.

WHO. 2009. World Health Organization: Global health risks: mortality and burden of disease attributable to selected major risks. Geneva, Switzerland: World Health Organization.

WHO. 2013. World Health Organization: Obesity and overweight. Retrieved June 17, 2013, from http://www.who.int/mediacentre/factsheets/fs311/en/

Williams, A. \& Bedward, J. 2001. Gender, culture and the generation gap: student and teacher perceptions of aspects of national curriculum physical education. Sport, Education and Society 6 (1), 53-66.

Whitehead, J. R. \& Corbin, C. B. 1997. Self-esteem in children and youth: the role of sport and physical education. In K. R. Fox (Ed.), The physical self. Champaign, IL: Human Kinetics, 175-203.

Wrench, A. \& Garrett, R. 2008. Pleasure and pain: experiences of fitness testing. European Physical Education Review 14 (3), 325-346.

Ylilahti, M. 2013. Itsestä kiinni. Etnografinen tutkimus työikäisten laitoskuntoutuksesta [It depenfs on you. Ethnographic study on rehabiliation of working age people]. Studies in Education, Psychology and Social Research 469. University of Jyväskylä.

Yli-Piipari, S. 2011. The development of students' physical education motivation and physical activity: a 3.5-year longitudinal study across grades 6 to 9 . Studies in Sport, Physical Education and Health 170. University of Jyväskylä.

Yli-Piipari, S., Jaakkola, T. \& Liukkonen, J. 2009. Koululaisten fyysisen aktiivisuuden seuranta 6. luokalta 8. luokalle. Liikunta ja Tiede 46 (6), 6167.

Yun, G. W. \& Park, S.-Y. 2011. Selective posting: willingness to post a message online. Journal of Computer-Mediated Communication 16 (2), 201-227.

Zacheus, T. \& Järvinen, T. 2007 "Opettaja pisti suksisauvalla selkään". Vuosina 1923-1988 syntyneiden suomalaisten kielteisiä koulukokemuksia ["The teacher poked me with the ski pole". Negative experiences of physical education at school as reported by Finns born between the years 19231988]. Kasvatus 38 (1), 17-28.

Zhu, X. 2013. Exploring students' conceptions and expectations of achievement in physical education. Measurement in Physical Education and Exercise Science 17 (1), 62-73. 


\section{APPENDICES}

APPENDIX 1 All the Internet discussion forums, which were used in data I and data II, including the group 'Others'

TABLE 1 All the Internet discussion forums used in data I

\begin{tabular}{llll}
\hline Data I: & & & \\
\hline site & discussion forum & messages & pseudonyms \\
& & & \\
1,4 & Eläinoikeusfoorumi & 23 & 17 \\
5,4 & Nappula- ja Junnufutis & 43 & 17 \\
7,6 & MyArtic & 19 & 15 \\
7,8 & ranneliike.net37 & 34 & \\
10,9 & Terhi Net & 47 & 36 \\
4,10 & YleX & 40 & 21 \\
5,10 & YleX & 80 & 53 \\
3,13 & Demi.fi & 150 & 65 \\
7,20 & Suomi24 & 11 & 7 \\
All together & & & \\
9 & & 450 & 265 \\
\hline
\end{tabular}

(The first 200 hits via the Google ${ }^{\mathrm{TM}}$ search conducted during week 15 in April 2007, where the first digit shows the site, the second the name of the discussion forum, the third the number of messages and the fourth the number of pseudonyms used.) 
TABLE 2 All the Internet discussion forums used in data II

\begin{tabular}{llll}
\hline Data II: & & & \\
\hline site & discussion forum & messages & pseudonyms \\
& & & \\
4,4 & Jonneweb & 12 & 10 \\
10,4 & nappulafutis & 43 & 17 \\
6,5 & Demi.fi & 40 & 40 \\
8,5 & perheklubi.net & 11 & 10 \\
10,5 & radola & 111 & 79 \\
4,6 & ranneliike & 11 & 9 \\
5,6 & koululainen & 11 & 6 \\
9,6 & suomenkuvalehti & 3 & 3 \\
2,7 & city & 38 & 18 \\
3,7 & ilotulite & 71 & 26 \\
3,8 & nuoret amputoidut & 14 & 6 \\
1,9 & kookosfoorum & 76 & 13 \\
5,9 & kulmassa & 13 & 9 \\
7,9 & jackO & 5 & 3 \\
8,9 & golfpiste & 5 & 4 \\
1,11 & thread/Suomi24 & 5 & 5 \\
2,11 & janoinen & 104 & 30 \\
7,11 & kaksplus & 18 & 15 \\
3,13 & peliplaneetta & 253 & 135 \\
1,14 & hommafoorum & 61 & 25 \\
7,14 & frendit.org & 98 & 37 \\
6,15 & kahvakuula & 5 & 4 \\
8,16 & habbo & 99 & 75 \\
3,18 & pakkotoisto & 85 & 68 \\
6,19 & suomi24 & 6 & 6 \\
5,20 & MyArtic & 13 & 10 \\
All together & & & \\
26 & & 1211 & 663 \\
\hline & & & \\
\hline
\end{tabular}

(The first 200 hits via the Google ${ }^{\mathrm{TM}}$ search conducted during week 15 in April 2012, where the first digit shows the site, the second the name of the discussion forum, the third the number of messages and the fourth the number of pseudonyms used.) 


\section{APPENDIX 2 Examples of the analytical phases with two original messages}

Example 1. The original message:

"I liked school PE, for me it was never a drag! In particular track and field and cross-country skiing were close to my heart because of my own hobbies. I was in both the school's baseball and basketball teams and represented the school in track and field and cross-country skiing competitions. The teachers were pretty much all pleasant and fair." $(7,8,16)$

(The coding numbers refer data I)

Phase 1.

If no negative comments about PE were contained in the message, it was labelled "positive".

This was a positive message.

Phase 2.

The messages were divided into smaller segments, 'opinions'.

"I liked school PE, for me it was never a drag!"

"In particular track and field and cross-country skiing were close to my heart because of my own hobbies."

"I was in both the school's baseball and basketball teams and represented the school in track and field and cross-country skiing competitions."

"The teachers were pretty much all pleasant and fair."

Phase 3.

All the 'opinions' were grouped into intrinsic and extrinsic factors.

"I liked school PE, for me it was never a drag!"

Intrinsic, range of emotions

"In particular track and field and cross-country skiing were close to my heart because of my own hobbies."

Intrinsic: sidesteps and explanations

"I was in both the school's baseball and basketball teams and represented the school in track and field and cross-country skiing competitions."

Extrinsic: curriculum

"The teachers were pretty much all pleasant and fair."

Extrinsic: teacher's personality and behavior

This message was finally categorized as a "positive" message with four different positive opinions: two intrinsic (range of emotions and sidesteps and explanations) and two extrinsic (curriculum and teacher's personality and behavior). 
Example 2. The original message:

"I' $m$ in high school, [PE] 3 times a week. The teacher's nice, and the PE classes are fun!:D Doing gym's a bit boring, but ballgames are fun." $(6,5,5)$.

(The coding numbers refer data II)

Phase 1.

If the message included a single positive comment while the rest was negative or vice versa, it was assigned to a group labelled "both".

This message included both positive and negative comments, and thus was coded "both".

Phase 2.

All the 'both' messages were reviewed and then recoded into three groups:

'Mainly positive', 'Mainly negative' and 'Mixture of both positive and negative'. This message included a negative comment, "Doing gym's a bit boring", while the rest was positive, so this message was coded as "Mainly positive".

Phase 3.

The message that was 'Mainly positive', included one opinion or a statement that was negative, "Doing gym's a bit boring". In such a message, the negative part was coded as an intrinsic or extrinsic factor.

The negative comment was about the curriculum, "Doing gym"

This message was finally categorized as a "both" message, which although "Mainly positive", also included a negative opinion (extrinsic; curriculum). 
APPENDIX 3 The collections of the forums of the other school subject's

TABLE 1 The collections of the Internet discussion forums of music

\begin{tabular}{lll}
\hline "koulumusiikki" [school music] & \\
\hline site & discussion forum & messages \\
& koululainen & 4 \\
1,8 & muusikoiden.net & 30 \\
19,10 & & \\
All together & & \\
2 & & \\
& & messages \\
\hline "koulun & musiikintunnit" [school music lessons] \\
\hline site & discussion forum & 37 \\
& & 4 \\
1,7 & naruto.fi & 60 \\
4,4 & pahvilaatikko & 14 \\
4,10 & muusikoiden.net & 30 \\
5,1 & kaksplus & 9 \\
10,3 & muusikoiden.net & 154 \\
17,5 & vauva.fi & \\
All together & & \\
6 & &
\end{tabular}

(The first 200 hits via the Google ${ }^{\mathrm{TM}}$ search conducted during the summer 2012 with following terms, where the first digit shows the site, the second the name of the discussion forum, the third the number of messages.) 
TABLE 2 The collections of the Internet discussion forums of mathematics

\begin{tabular}{lll}
\hline "matikka" [math] & \\
\hline site & discussion forum & messages \\
& & \\
5,1 & suomi24 & 6 \\
7,4 & älyvuoto & 9 \\
12,9 & nuoret.info & 4 \\
All together & & \\
3 & & 19
\end{tabular}

\begin{tabular}{lll}
\hline \multicolumn{2}{l}{ "koulumatikka" [school math] } & \\
\hline site & discussion forum & messages \\
& potku.net & 200 \\
1,10 & peliplaneetta & 25 \\
5,9 & näkökulma & 5 \\
6,5 & suomi24 & 17 \\
6,10 & suomi24 & 4 \\
8,2 & suomi 24 & 5 \\
8,3 & suomi 24 & 11 \\
8,4 & suomi24 & 17 \\
9,10 & suomi24 & 16 \\
10,6 & suomi24 & 16 \\
11,6 & kaksplus & 8 \\
14,7 & suomi24 & 9 \\
15,8 & kaksplus & 10 \\
16,10 & & 343 \\
All together & & \\
13 & &
\end{tabular}

TABLE 3 The collections of the Internet discussion forums of Finnish language

\begin{tabular}{|c|c|c|}
\hline \multicolumn{3}{|c|}{ "äidinkielen tunnit" [Finnish language lessons] } \\
\hline site & discussion forum & messages \\
\hline 3,5 & suomi24 & 9 \\
\hline 4,9 & vauva.fi & 11 \\
\hline \multicolumn{3}{|c|}{ all together } \\
\hline 2 & & 20 \\
\hline
\end{tabular}


TABLE 4 The collections of the Internet discussion forums of Swedish language

\begin{tabular}{lll}
\hline "pakkoruotsi" [compulsory Swedish] & \\
\hline site & discussion forum & messages \\
& & \\
1,8 & tiede.fi & 4589 \\
4,5 & yle.fi & 10 \\
6,3 & iltalehti.fi & 5 \\
7,2 & vauva.fi & 2 \\
7,10 & iltalehti & 4 \\
8,9 & iltalehti.fi & 1 \\
9,2 & kaleva.fi & 70 \\
9,7 & iltalehti & 10 \\
10,6 & finn-guild & 74 \\
11,5 & iltalehti & 7 \\
11,6 & iltalehti & 6 \\
11,7 & tiede.fi & 9 \\
12,4 & länsiväylä & 90 \\
12,10 & vauva.fi & 13 \\
13,10 & vauva.fi & 30 \\
16,10 & kaleva.fi & 47 \\
19,3 & iltalehti.fi & 10 \\
19,8 & vauva.fi & 24 \\
All together & & \\
18 & & 5001 \\
& & \\
\hline
\end{tabular}




\begin{tabular}{|c|c|c|}
\hline \multicolumn{3}{|c|}{ "kouluruotsi" [school Swedish] } \\
\hline site & discussion forum & messages \\
\hline 1,7 & suomi24 & 1 \\
\hline 2,4 & ksml & 15 \\
\hline 2,6 & suomi24 & 1 \\
\hline 2,7 & suomi24 & 2 \\
\hline 3,4 & ksml & 3 \\
\hline 3,5 & ksml & 10 \\
\hline 3,6 & ravia.fi & 1 \\
\hline 3,7 & thread suomi24 & 3 \\
\hline 3,10 & huuto.net & 70 \\
\hline 4,7 & suomi24 & 87 \\
\hline 4,8 & suomi24 & 32 \\
\hline 5,7 & agricola & 5 \\
\hline 5,8 & fsnordic & 5 \\
\hline 5,10 & plaza.fi & 28 \\
\hline 6,8 & thread suomi24 & 17 \\
\hline 6,9 & flightforum.fi & 20 \\
\hline 7,1 & iltalehti & 10 \\
\hline 7,4 & vauva.fi & 21 \\
\hline 8,8 & iltalehti & 10 \\
\hline 9,4 & suomi24 & 89 \\
\hline 9,6 & iltalehti & 10 \\
\hline 10,4 & suomi24 & 26 \\
\hline 10,5 & suomi24 & 5 \\
\hline 11,1 & hoitajat.net & 6 \\
\hline 11,2 & vauva.fi & 40 \\
\hline 11,10 & iltalehti.fi & 10 \\
\hline 12,8 & suomi24 & 15 \\
\hline 12,9 & suomi24 & 3 \\
\hline 13,1 & näkökulma.net & 5 \\
\hline 14,3 & thread suomi24 & 7 \\
\hline 15,5 & yle.fi & 10 \\
\hline 15,8 & vauva.fi & 29 \\
\hline 16,4 & suomi24 & 7 \\
\hline 16,9 & taloussanomat & 49 \\
\hline 17,3 & suomi24 & 5 \\
\hline 20,6 & demi.fi & 22 \\
\hline \multicolumn{3}{|c|}{ All together } \\
\hline 36 & & 679 \\
\hline
\end{tabular}

(The first 200 hits via the Google ${ }^{\mathrm{TM}}$ search conducted during the summer 2012 with following terms, where the first digit shows the site, the second the name of the discussion forum, the third the number of messages.) 


\title{
ORIGINAL PAPERS
}

\section{I \\ STUDENT'S VOICE ONLINE: \\ EXPERIENCES OF PE IN FINNISH SCHOOLS}

\author{
by \\ Lauritsalo Kirsti, Sääkslahti Arja \& Rasku-Puttonen Helena 2012 \\ Advances in Physical Education 2 (3), 126-131. \\ DOI: $10.4236 /$ ape.2012.23022
}

Reproduced with kind permission by Scientific Research Publishing Inc. 


\title{
Student's Voice Online: Experiences of PE in Finnish Schools
}

\author{
Kirsti Lauritsalo ${ }^{1 *}$, Arja Sääkslahti ${ }^{2}$, Helena Rasku-Puttonen ${ }^{1}$ \\ ${ }^{1}$ Department of Teacher Education, University of Jyväskylä, Jyväskylä, Finland \\ ${ }^{2}$ Department of Sport Sciences, University of Jyväskylä, Jyväskylä, Finland \\ Email: "kirsti.lauritsalo@jyu.fi \\ Received April 24 $4^{\text {th }}, 2012$; revised May $27^{\text {th }}, 2012$; accepted June $8^{\text {th }}, 2012$
}

\begin{abstract}
The aim of this descriptive study was to find out how people describe their experiences of physical education (PE) in Internet discussion forums. The data for this study were collected during one randomly chosen week in April 2007 via a Google ${ }^{\mathrm{TM}}$ search using the Finnish word "koululiikunta" [school PE]. The sen week in April 2007 via a Google ${ }^{\mathrm{TM}}$ search using the Finnish word "koululiikunta" [school PE]. The
first 200 hits lead into nine discussion forums, which were analysed by using qualitative content analysis. These nine discussion forums included all together 356 messages. For searching these discussion forums no criteria about the writers' age, race, class, gender or other were set. The messages were coded with sequential classification and grouped into positive, negative and both positive and negative messages. The results revealed that the messages were positive $(12 \%)$, both $(24 \%)$ and negative $(64 \%)$. In the positive messages the focus was on physical education in general and the experiences were more related to the (the In the negative messages ers' messages, in particular where they reported negative experiences revealed strongly held feelings an emotions. We need to widen our understanding of the relationship between PE and the contents of teache education curriculum to guarantee every pupil the opportunity to have positive experiences in PE. These, in turn, help to create a basis for life-long physical activity and a positive relation to one's body, the main target of PE. In PE one's own body and feelings are intensively involved at a time when vivid and memorable experiences are taking place for a young person and lasting damage can easily be done.

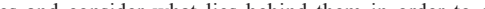
pedagogy and a safe PE learning environment.
\end{abstract}

Keywords: School Physical Education; Peoples' Experiences; Internet; Discussion Forums

\section{Introduction}

The large scale of discussion forums allows people to network easily. When doing this the individual can guarantee that the message is sent without embarrassment, meaning that whatever one writes can be said anonymously. Different kinds of discussion forums make it possible for people to express themselves through real or fictitious messages (Markham, 2007). The personality itself can be totally hidden behind the screen (Markham, 1998; Tapscott, 2009). Such forums are places for bringing out the opinions, feelings and experiences created by people interested in the same topic published on the Internet. Joining is not dependent on time or place. In Finland about $85 \%$ of people have access to the Internet at home and almost all people (89\%) under 74 years use the Internet (Statistics Finland, 2011). Of all Internet users in Finland, 44\% of men and $45 \%$ of women use the net for chat or discussion forums (Statistics Finland, 2011). A user is likely to have joined a Web forum voluntarily. He/she has a need to comment, object, defend or introduce something new in order to share opinions about the subject with others. The writer has every opportunity to tell the truth and describe a real experience, but just as easily the story told may be wholly imagined. Control of the self, conditions and presentation is an important benefit of online communication (Markham, 1998) Deep-felt emotions, disappointments and experiences create strong feelings that people want to write about and share with others. It seems to be easier to express these negative feelings online (e.g.

${ }^{*}$ Corresponding author.
Ransom, La Guardia, Woody, \& Boyd, 2010; Seale, Charteris-Black, MacFarlane, \& McPherson, 2010). Physical education aims at producing positive experiences in schools (NASPE, 2004). However, it is a subject that strongly divides people's opinions. The present study aimed to examine how people describe their experiences of physical education (PE) in the Internet forums. Thus far, there has not been enough research about the discussions around physical education in the Internet forums.

\section{Earlier Studies Concerning School PE Experiences}

Today's sedentary lifestyle has been accompanied by global concern about the resultant increase in overweight (McKenzie, 2007), while at the same time health-related physical education aims to promote life-long physical activity. How PE is experienced at school is important for the future sport and health be haviour of the student him/herself (Trudeau \& Shephard, 2005; Yli-Piipari, 2011). Therefore, today's schools and the prevailing physical education culture are under strong pressure to produce positive student experiences.

According to the substantial body of earlier research most pupils (around 75\%) like physical education at school (e.g. Carlson, 1995; Dyson, 2006; Groves \& Laws, 2000; Rikard \& Banville, 2006; Subramaniam \& Silverman, 2007). Researchers chiefly highlighted positive experiences despite the fact that opposite opinions among the pupils also exist. In researching the relationship between PE bibliographies and the PE teaching practices of classroom teachers, both quantitative and qualitative analyses (Morgan \& Hansen, 2008) showed that negative PE 
experiences were common within the teachers' own school time memories. The main reason given for bad experiences were the feeling of not being taught, not having learned and the teachers being "tyrants". Some teachers produced negative experiences related to the strong atmosphere of competition, in which the pupils felt uncoordinated and scared. Such a situation can lead to avoidance and alienation in PE. Carlson (1995) published an alienation-nonalienation model for be in investigating student alienation from PE in schools. She found that around $80 \%$ of students enjoyed and had positive experiences of PE. She was worried about the remaining $20 \%$, for whom meaninglessness (understood as lack of personal meaning), powerlessness and isolation were the three main feelings that caused those student to have a negative attitude towards PE. In their study, Williams and Bedward (2001) focused on issues related to female gender and culture and the differences between teachers' and students' constructions of physical activity, sport and leisure. They found that some activities, e.g. football and swimming, and having a school uniform policy, were highly related to cultural differences and suggested that "the complexity of issues of culture and gender in relation to physical activity should not be underestimated" (Williams \& Bedward, 2001: p. 63). Rikard and Banville (2006) found that most high school students like PE, the main reasons given being fun, liking sports in general and liking the activity offered. The most common reasons for disliking PE were dislike of the activity offered, too much teacher talk, too little playing time, and that it was boring.

In Finland findings regarding experiences of PE have mainly been positive (e.g. Palomäki \& Heikinaro-Johansson, 2011; Yli-Piipari, 2011). According to the Finnish national core curriculum for basic education (2004) the aim of PE is to build the pupil's self-esteem and a positive physical self-concept through favourable PE experiences and to encourage cooperativeness and positive future sport and health behaviour. These objects are in line with the international targets of physical education (NASPE, 2004).

An important question, however, remains: why is it that $20 \%$ $-30 \%$ of pupils do not like physical education or have negative feelings towards it? Because the Internet offers a "safe" channel to express one's emotions and describe one's experiences during PE classes, it might be fruitful to analyze how PE experiences are described through this medium.

\section{Purpose of the Study}

A student's experience of PE at school is important for his or her future sport and health behaviour. For this reason schools and physical education culture are under strong pressure to produce increasingly positive student experiences. The aim of this descriptive study was to find out what kind of PE experiences people describe in Internet discussion forums.

\section{Methods}

\section{Data Collection}

The data for this study were collected from Internet discussion forums during a randomly chosen week in April 2007. During the weeks before that date nothing in particular had happened in Finland to prompt any special reason to motivate the discussion about PE. The data were collected using a Google ${ }^{\mathrm{TM}}$ search engine that shows the requested documents according to the number and quality of the links leading to them. It is the most widely known and used search engine in Finland. Via a Google $\mathrm{TM}^{\mathrm{TM}}$ search with the broad term "koululiikunta" ("school PE" in Finnish) the first 200 hits included nine discussion forums. Since no criteria (age, race, class, gender or other) were set, these Web forums represented a variety of areas including discussions on animal rights [www.oikeuttaelaimille.net], junior football [www.nappulafutis.com], health [www.myartic.net], overweight [www.terhi.net, http://chat.yle.fi] and memories of sport in school [http://ranneliike.net; http://chat.yle.fi; http://demi.fi,; http://keskustelu.suomi.24.fi]. All nine forums were selected, numbered from one to nine and analyzed further. The forums contained between $11-150$ messages varying in length. Altogether the nine discussion forums yielded 450 separate messages.

\section{Data Coding}

Using qualitative content analysis (Patton, 2002), going through and reading the messages several times, they seemed to fall clearly into four different groups.

1) If no negative comments about PE were contained in the message it was called "positive". Also a message stating an opinion or agreement with the former writer and not containing anything negative was included in this group.

2) If the message included a single positive comment while the rest was negative - or vice versa - it was assigned to a group labelled "both".

3) If the message contained no positive comment it was called "negative".

4) The fourth group consisted of messages with various topics mixed in with the issue of PE. This group was called "other". The messages in this group included, for example, messages about eating and being overweight, smoking, the writer's own physical condition and other school subjects.

These groups were labelled positive, negative, both positive and negative (later called both for short) and other. After reading the messages in the "other" group more closely, the whole group was discarded because it did not directly com- monthe topic of this research. Having done this, 356 messages remained. To ensure reliability the data were coded with sequential classification within six months. In case of unclear or ambiguous messages our research team classified them as a team in order to avoid subjectivity.

\section{The Ethics of Internet Research}

The Internet can be seen as a form of cultural production where people build virtual persons and social images for the self and others (e.g. Basset \& O'Riordan, 2002). In line with other researchers (see e.g. Bruckman, 2002), we see the Internet as a social environment for publishing one's thoughts and feelings. We also assume, like Pitts (2004), that the web forums we research are "truthful" (see Hine, 2000), and that the issues the writers raise are real for themselves. In our data the 365 messages were posted by 239 different pseudonyms. Trolls (Tepper, 1997), seeking to disrupt these forums with provocative messages about school PE, did not seem to be present. This was not, however, empirically verified and must thus be considered a limitation of this study. The ethics of online research depend on the nature of the research and on the target group (e.g. Basset \& O'Riordan, 2002). In this study the data were collected from open forums, which are available to everyone, whether as a subscriber or reader. Discussions and opinions exist in these open 
forums independently of research purposes. Out of the nine forums only two (animal rights and junior football) could be considered as primarily for a more limited audience, although they too were openly accessible. By chance, the selected forum were discussing PE during that particular week. No claims about the writers' off-line identities can be made.

\section{Results}

The results of this study reveal how the writers in the Interne discussion forums described their experiences of PE in Finnish schools. Of the 356 messages $12 \%$ were positive $(n=41), 24 \%$ included both feelings $(\mathrm{n}=87)$ and $64 \%$ were negative messages $(n=228)$. The purpose was to gain an overview of the kinds of experiences people recounted in the Web forums. The results and excerpts are given in order of frequency. All the writers behind the messages referred to in this study were given codes in which the first digit indicates the discussion forum and the second the running number of the message. Since the messages were written anonymously the gender and age of the writers are unknown. In addition the time when the writers experience school PE varies. The original messages have been translated from Finnish into English for this report by a native English speaker translator.

\section{Liked School PE}

Positive messages included statements about the writer's success in PE, the writer's development when his/her skills were not yet very advanced and positive attitude towards the subject. Good memories about PE teachers, their enthusiasm and assistance as well as their positive attitude towards sport as a hobby were also mentioned.

"The best things in PE were the games and even the individual sports; our teachers encouraged the weaker ones too to join in, and nobody was given a hard time if a girl couldn't really take part or didn't understand. Teachers like that are rare." $(4,25)$

The wide range of $\mathrm{PE}$, especially during the higher classes, the importance and the amount of PE lessons and good feeling about competitions between schools were also mentioned. What also seemed to be important was a good class atmosphere and environment, where the pupils felt accepted as a part of the group.

"We've always had a good PE group in which it's been fun to do things together. Myself, I've never been brilliant at PE, but I'm reasonably good at most things. Ice skating is the only thing that genuinely causes me problems. I've never been tremendously popular among the other pupils, but in PE lessons I felt I was welcome in the group.' $(8,14)$

These positive results are in line with those of earlier research (Groves \& Laws, 2000; Rikard \& Banville, 2006; Strean, 2009).

\section{Like PE, but..}

In the messages referring to both positive and negative experiences, opinions were very different and conflicted with each other. The main focus in these messages was on the teacher and to almost the same degree the writers' self-esteem. In some messages the writer liked the teacher but hated something about the particular sport itself and in other messages just the opposite Many messages described one unpleasant or traumatic experience while the rest of the message was positive.

"The same PE teacher from seventh grade right through to the end of upper secondary school, yippee! And exactly the same stuff EVERY YEAR! Compulsory! By the way, my mum had the same teacher as well... and no doubt she's still there, that dry old bag of bones." $(5,47)$

In this group the memories of the lower grades were generally not as positive as later on, but again in some messages it was just the opposite. The lower comprehensive school teacher's skills were complained about more than the subject teacher's teaching skills in PE in the upper levels of comprehensive school (see also Strean, 2009).

"In the lower comprehensive our PE teacher was abysmal. In his lessons roughly $80 \%$ of the time was devoted to him explaining how things should be done, and then for the remaining ten minutes we played according to "simplified" rules. In the upper level of comprehensive school the $\mathrm{PE}$ lessons have been significantly better because we've had a professional PE teacher." $(2,12)$

Attitudes towards one' own body, being overweight and teenage in general were frequently presented. In particular, the compulsory showering after PE lessons was a highly controversial topic. Opinions were divided over team versus individual sports. Some wrote in favour of team sports but described negative experiences of individual sports, and vice versa. It was impossible to identify sports that were generally liked or disliked, because opinions differed so widely (see also Williams \& Bedward, 2001). The monotony of sports was another common complaint. Writers reposted doing the same sports year after year finding this repeated boring.

"Personally, it's not like I hate school PE, but team disciplines in particular piss me right off. Swimming and orienteering, on the other hand, are really great sports." $(8,41)$

\section{PE Is Traumatic}

The biggest number of messages fell into the negative category. The teacher was the focus of most of them. The teacher' behaviour was often mentioned. A common complaint was the teacher's attitude, which was even seen as teachers being 'Nazis'. Also hate towards teachers was strong. The teachers' way of teaching the subject or of treating the pupils was heavily criticized. Descriptions along these lines have also been found earlier (Morgan \& Hansen, 2008; Rikard \& Banville, 2006; Strean, 2009; Trout \& Graber, 2009; Williams \& Bedward, 2001).

"Here's to my PE teacher in lower comprehensive, he was a complete Nazi, I HATED him. Always getting at the ones who couldn't do things, shouting, taking the mickey out of people, behaving like a total sadist. Once he even laughed when I got hit in the nuts by a ball during the lesson. I was pretty lacking in confidence anyway... well, that really didn't make me feel any better or help my self-image." $(4,31)$

The class environment, especially the competition and depressing nature of the interaction between the pupils came up in 
many ways in a large number of messages. The other pupils watching while one pupil was doing an exercise were an unpleasant moments. These results support earlier findings (e.g. Morgan \& Hansen, 2008; Trout \& Graber, 2009).

"The teacher actually had less influence than my classmates. At the end of the day the teacher was pretty powerless to do anything about the internal hierarchies in our class. These can't be altered by simply changing the way teams are picked. However you look at it, for a long period PE was a drag, the pressures to perform enormous, and even now I don't want to know when it comes to team games." $(4,20)$

Self-esteem was often mentioned from the bodily attractiveness and sports competence point of view (Fox \& Corbin, 1989). In particular pupils who were more grown up and physically more mature than the others felt embarrassed. Physical fitness and an overweight body were often subjects of comparison and caused bad experiences. Skills or the lack of them as well were mentioned many times.

"Traumatic. My grade for PE was 6 - 7. From the first grade right through to the end of upper secondary school, for a full twelve years PE has caused me stomach cramps and anxiety. The most enjoyable school days were those when there was no PE. Since I was the diligent sort I didn't even dare to skip the PE classes. Throughout comprehensive school everybody got down on me in PE lessons, pupils and teachers alike, because I was totally useless. In upper secondary school things were a bit more civilized, but still caused me grief." $(4,35)$

Some sports created strong negative feelings and anxiety that affected pupils' attitude towards $\mathrm{PE}$ as a whole during thei school years. Team sport and playing games were most often mentioned, but individual sports received negative feedback as well. (See e.g. Rikard \& Banville, 2006)

"One word: gymnastics. I'll remember forever the humiliation, when I couldn't do any of the compulsory exercises. I couldn't get over the horse, and the teacher had to LIFT me over. I was so, so embarrassed. And what's that movement, when you kind of have to swing around a horizontal bar? Well, I didn't make it even onto the bar. I couldn't do a cartwheel. I couldn't even do a somersault. Finally in the upper comprehensive I learned to bounce on the trampoline, and even there I flew off and hit the ground. I hate, hate, repeat, hate gymnastics." $(5,19)$

In this group of negative messages the facilities and the equipment were important factors as well. Small gyms or lack of them, unpleasant dressing rooms and showers, different items of sports equipment and carrying them to school-like crosscountry skis or ice skates-were mentioned. An interesting group of messages dealt with the question of the leather material used in sports equipment.

“... what should you do, when almost every item of sports equipment is made of leather? Basketballs, footballs, baseball gloves... My old skates are made of leather, and skating on the timetable?" $(1,1)$

"First of all we lugged the skis to school in the morning, and then stuck them in a really tightly packed store room.
In spite of the racks the skis in the store room were in a totally chaotic state and finding one's own skis amongst all the rest was a real struggle. If you didn't have your own skis then you had to use the school skis, which didn't usually match, and which were straight from the Stone Age. During PE classes we walked a few kilometres to the sawdust circuit carrying our skis and then staggered around the track, all the same if it was minus 25 or we were up to our ankles in water. Then we walked back carrying our skis and watched as the PE teacher went shooting past in his car." $(7,3)$

Testing and evaluation as well as report numbers for PE have left bad memories in some of the writers' minds. This is a common result found in many earlier studies (Hartmann, Zahner, Pühse, Schneider, Puder, \& Kriemler, 2009; Trout \& Graber, 2009; Wrench \& Garrett, 2008)

"We had fitness tests, at which I was naturally absolute rubbish. Doing so badly was horrible and unpleasant in itself, but the final humiliation came when on the next occasion the teacher gave us all a handout showing each pupil's results in the different parts of these tests. My name showed up in virtually every activity right at the bottom of the list." $(5,31)$

To summarize the present results, in the positive message the focus tend to be physical education in general and personal experiences. The messages dealt with the writer's sport competence and general physical self-worth. In the negative messages the emphasis was more on factors external to the writer like the teacher or the other pupils, the curriculum, facilities and equipment, and also showering.

\section{Discussion and Conclusion}

The aim of this study was to examine what kinds of physical education experiences in school are recounted in Internet discussion forums. The main findings were the themes that the writers sent into cyberspace. The messages posted in the Internet discussion forums studied here referred to negative experiences more frequently and more vehemently than has been previously reported in PE studies. Despite sometimes even very strong expressions of disliking physical education it is important for pedagogical reasons to sort out what kind of situations cause negative messages. Earlier studies have found that most pupils like physical education in school. These prior results have been based on surveys and questionnaires (Carlson, 1995; Palomäki \& Heikinaro-Johansson, 2011), interviews (Carlson, 1995; Williams \& Bedward, 2001) and through the analysis of diaries and classroom observations (Groves \& Laws, 2000) The use of the open discussion forums as data base could be seen as a further, nontraditional, possibility to listen to students' voices. When interpreting these results we have to emphasise that the messages are from writers in Internet discussion forum and therefore not representative of all school pupils or all people. The Internet as an anonymous forum offers an easy opportunity for the expression of the strong feelings and often in a very extreme way. However, this method of data collecting enables the description of experiences that might be too personal to describe by other means. It might be easier to talk about very sensitive, even intimate matters on the Internet (Pitts, 2001; Seale et al., 2010) 
Bad memories of body image and physical self-esteem (Fox \& Corbin, 1989) and feelings of hurt caused by a teacher or peers may remain with the writer for life (Strean, 2009). They may have future effects, where such individuals become PE teachers themselves (Morgan \& Hansen, 2008). The results of this study verify the target of PE, building up pupil's self-esteem and a positive physical self-concept (NASPE, 2004). This should effect the pedagogical decisions teachers make during PE lessons. Also extrinsic factors (e.g. facilities) seem to have a strong role, which should be taken into consideration while planning the resources of teaching for the future.

The findings are related to the method used to collect the data and the reality that only certain types of people are active in Internet forums. It is possible on the Internet to write about things that would not necessarily emerge in questionnaires. One particular example that shows the possibilities of the method used in this study, were some of the messages that were captured by the broad search term "school PE", such as the issue of animal rights. Most probably the aversion to using leather (in balls, baseball mitts, skates) during PE would never have emerged using other, less open-ended data sources. Such issues have not previously been noted out in the PE context.

The method used in this study clearly offers a new approach for research on people's opinions. Relatively few studies have used Internet forums in this way. Because the present data were collected from Web forums the research process did not influence the target group or their opinions (Seale et al., 2010). In some studies researchers investigate the subject in a specific forum specially set up for the purpose of their research. This was not the case in this study. Discussions and opinions exist in forums independently of research purposes. Data collected in this way are totally unaffected by social pressure or the need to please interviewers or teachers (cf. Seale et al., 2010). However, there may be an unwritten imperative in forums to compete with previous writers and make one's experiences sound even worse or better than theirs (Hagger, Wood, Stiff, \& Chatzisarantis, 2009). It may be that the Internet encourages more forthright expression and that negative examples fuel the effects of other writers. Also, some controversial messages (trolling) might be posted with the express purpose of inciting strong reactions (flaming) from people (Millard, 1997; Tepper, 1997).

People writing in Web forums are active in giving and receiving emotional and informational support (Ransom et al., 2010; Pitts, 2001; Seale et al., 2010). Readers cannot know if the writers have really experienced the things they write about or whether they are dramatizations of their experiences or even wholly imaginary. These issues remain unresolved in this study.

Internet forums open the door to an inner world where neither the writers nor the messages are there explicitly for research purposes. This provides an opportunity to follow imperceptibly a conversation in its authentic environment. The clea difference between the positive and negative groups is in the strength of the emotions the writers describe. It is interesting to observe what major consequences small and sporadic experiences can have. It would be interesting to know what the true implications might be of the writers being hidden behind screen. Sometimes a person's own uncertainty or ambivalence regarding his/her self-esteem underlies negative experience (Fox \& Corbin, 1989). To obtain the most inclusive view of these phenomena different data collection methods should be used in combination.

Some clear limitations in this study should be acknowledged.
The first is that we do not know the identity of the person behind the computer. Tapscott argues that "they're screenagers, Net addicted, losing their social skills, and they have no time for sports or healthy activities. Time spent online could have been devoted to sports and face-to-face conversation; the result is a generation of awkward, fat people" (Tapscott, 2009: p. 3). If that is the case, it might mean that these individuals have difficulties coming to terms with the normal and natural effect of their own body and feel uncomfortable with it. Since the participants write anonymously, it is impossible to discover their cultural background, race, schooling, gender or age. In Finland, in most cases from the third grade ( $8-9$ years of age) onward girls and boys do PE separately: this may have influenced the view of some of the writers. Owing to these limitations, issues concerning the writer's personal background were not in focus in this study, and should therefore be examined in future research. In relation to discussions forums it is important to understand that a limited population segment find such sites, read the messages and react. In Finland, however, quite a large number of people use the Web forums (Statistics Finland, 2011). The present results are based on all the messages posted in nine Web forums during a specific period. The Internet is one way of listening to peoples' voices. When decoding the data one challenge is to be able to reach the writer's feelings. Another challenge is to understand and construe a message the way the writer intended. The smilies and other emoticons used in the messages helped to confirm the interpretation of the writer's feelings.

Since people are not physically active enough, it is important to find out and analyze in more detail what lies behind this. Our findings imply that physical education does not provide everyone with enjoyable experiences and happy memories. It would be helpful for teachers and teacher educators to be aware of the feelings that PE arouses in order to develop PE pedagogy and the PE learning environment to the advantage of all students. PE teachers make valuable and challenging work with sensitive students. Today's new school-going generation may have a different relationship with their bodies; if so, this challenges PE teachers to find new ways to encourage students to adopt a physically active lifestyle.

\section{REFERENCES}

Bassett, E. H., \& O'Riordan, K. (2002). Ethics of Internet research: Contesting the human subjects research model. Ethics and Information Technology, 4, 233-247. doi:10.1023/A:1021319125207

Bruckman, A. (2002). Studying the amateur artist: A perspective on disguising data collected in human subjects research on the Internet. Ethics and Information Technology, 4, 217-231

doi:10.1023/A:1021316409277

Carlson, T. (1995). We hate gym: Student alienation from physical education. Journal of Teaching in Physical Education, 14, 467-477.

Dyson, B. (2006). Students' perspectives of physical education. In D. Kirk, D. Macdonald, \& M. O'Sullivan (Eds.), The handbook of physical education (pp. 326-346). London: SAGE Publications.

Finnish National Core Curriculum for Basic Education (2004). URL (last checked 9 June 2012) http://www oph fi/english

Fox, K. R., \& Corbin, C. B. (1989). The physical self-perception profile: Fox, K. R., \& Corbin, C. B. (1989). The physical self-perception profile:
Development and preliminary validation. Journal of Sport \& ExerDevelopment and preliminary
cise Psychology, 4, 408-430.

Groves, S., \& Laws, C. (2000). Children's experiences of physical education. European Journal of Physical Education, 5, 19-27. doi: 10.1080/174089800050102

Hagger, M., Wood, C., Stiff, C. \& Chatzisarantis, N. (2009). The strength 
model of self regulation failure and health-related behaviour. Health Psychology Review, 3, 208-238. doi:10.1080/17437190903414387 Hartmann, T., Zahner, L., Pühse, U., Schneider, S., Puder, J. \& KriemHartmann, T., Zahner, L., Punse, U., Schneider, S., Puder, J. \& Kriem-
ler, S. (2009). Physical activity, bodyweight, health and fear of negaler, S. (2009). Physical activity, bodyweight, health and fear of nega-
tive evaluation in primary school children. Scandinavian Journal of tive evaluation in primary school children. Scan
Medicine and Science in Sports, 20, e27-e34.

Medicine and Science in Sports, 20, e27.
doi:10.1111/i.1600-0838.2009.00888.x

doi:10.1111/j.1600-0838.2009.00888.x
Hine, C. (2000). Virtual Ethnography. London: Sage Publications. Hine, C. (2000). Virtual Ethnography. London: Sage Publications.
Markham, A. N. (1998). Life online: Researching real experience in virtual space. Walnut Creek, CA: AltaMira Press.

Markham, A. N. (2007). The Internet as research context. In C. Seale, G. Gobo, J. Gubrium, \& D. Silverman (Eds.), Qualitative research practice (pp. 328-344). London: Sage Publications.

Mc Kenzie, T. (2007) The preparation of physical educators: A public health perspective. Quest, 59, 346-357.

doi:10.1080/00336297.2007.10483557

Millard, W. B. (1997). I flamed freud: A case study in teletextual incendiarism. In D. Porter (Ed.) Internet culture (pp. 145-159). New York: Routledge.

Morgan, P., \& Hansen, V. (2008). The relationship between PE biographies and PE teaching practices of classroom teachers. Sport, Edu-
rang raphies and PE teaching practices of classroom teachers. Sport, Edu-
cation and Society, 13, 373-391. doi:10.1080/13573320802444994 cation and Society, 13, 373-391. doi:10.1080/13573320802444994
National Association for Sport and Physical Education (2004). Moving into the future: National standards for physical education. Reston NASPE Publications.

Palomäki, S., \& Heikinaro-Johansson, P. (2011). Liikunnan oppimistulosten seuranta-arviointi perusopetuksessa 2010 (A follow up evaluation of physical education learning outcomes). Helsinki: Opetushallitus.

Patton, M. (2002). Qualitative research \& evaluation methods. Thousand Oaks, CA. Sage.

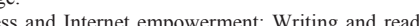
ing breast cancer in cyberspace. Health, 8, 33-59. ing breast cancer in cyberspace.

Ransom, D. C., La Guardia, J. G., Woody, E. Z., \& Boyd, J. L. (2010).

Ransom, D. C., La Guardia, J. G., Woody, E. Z., \& Boyd, J. L. (2010).
Interpersonal interactions on online forums addressing eating concerns. International Journal of Eating Disorders, 43, 161-170.
Rikard, G. L., \& Banville, D. (2006). High school students attitudes about physical education. Sport, Education and Society, 4, 385-400. doi: 10.1080/13573320600924882

Seale, C., Charteris-Black, J., MacFarlane, A., \& McPherson, A. (2010). Interviews and Internet forums: A comparison of two sources of Interviews and Internet forums: A comparison of two so
qualitative data. Qualitative Health Research, 20, 595-606. qualitative data. Qualitative Heal
doi:10.1177/1049732309354094

Subramaniam, P. R., \& Silverman, S. (2007). Middle school students' Subramaniam, P. R., \& Silverman, S. (2007). Middle school students'
attitudes towards physical education. Teaching and Teacher Educaattitudes towards physical education. Teaching a
tion, 23, 602-611. doi:10.1016/j.tate.2007.02.003

Statistics Finland (2011). Use of information and communications technology. URL (last checked 9 June 2012).

http://www.stat.fi/til/sutivi/index en.htm

Strean, W. B. (2009). Remembering instructors: Play, pain and pedagogy. Qualitative Research in Sport and Exercise, 1, 210-220. doi:10.1080/19398440903192290

Tapscott, D. (2009). Grown up digital: How the net generation is changing your world. New York: McGraw-Hill

ing your world. New York: McGraw-Hill.
Tepper, M. (1997). Usenet communities and the cultural politics of Tepper, M. (1997). Usenet communities and the cultural politics of
information. In D. Porter (Ed.), Internet culture ( $\mathrm{pp}$. 39-54). New York: Routledge.

Trout, J., \& Graber, K. (2009). Perceptions of overweight students concerning their experiences in physical education. Journal of Teaching in Physical Education, 28, 272-292.

Trudeau, F., \& Shephard, R. J. (2005). Contribution of school programmes to physical activity levels and attitudes in children and adults. Sport Medicine, 35, 89-105. doi:10.2165/00007256-200535020-00001

Williams, A., \& Bedward, J. (2001). Gender, culture and the generation gap: Student and teacher perceptions of aspects of national curriculum physical education. Sport, Education and Society, 1, 53-66. doi: $10.1080 / 713696037$

Wrench, A., \& Garrett, R. (2008). Pleasure and pain: Experiences of fitness testing. European Physical Education Review, 14, 325-346. doi:10.1177/1356336X08095669

Yli-Piipari, S. (2011). The development of students' physical education motivation and physical activity: A 3.5-year longitudinal study across grades 6 to 9. Ph.D. Thesis, Jyväskylä: University of Jyväskylä. 


\title{
SCHOOL PE THROUGH INTERNET DISCUSSION FORUMS
}

\author{
by
}

Lauritsalo Kirsti, Sääkslahti Arja \& Rasku-Puttonen Helena 2013

Physical Education and Sport Pedagogy online / in press.

DOI:10.1080/17408989.2013.788144

Reproduced with kind permission by Taylor \& Francis Publishing Group. 


\section{School PE through Internet discussion forums}

Kirsti Lauritsalo $^{\mathrm{a} *}$, Arja Sääkslahti ${ }^{\mathrm{b}}$ and Helena Rasku-Puttonen ${ }^{\mathrm{a}}$

${ }^{a}$ Department of Teacher Education, University of Jyväskylä, PO Box 35, FIN-40014, Finland; ${ }^{b}$ Department of Sport Sciences, University of Jyväskylä, PO Box 35, FIN-40014, Finland

(Received 22 January 2011; final version received 17 December 2012)

Background: Physical education is a subject that generates strong feelings and emotions, as can be seen in written accounts of PE experiences. It is also important to listen to students' voices in the research context. Nowadays, students can be listened to in a new way - through the Internet. Various discussion forums on the Internet make it possible for people to express themselves through real or imagined messages. It might be easier to express highly sensitive and even intimate thoughts on the Internet.

Thus, the Internet might be an interesting open forum for teachers to think about new ways of developing teaching practices that would reduce negative experiences of PE. Purpose: The purpose of this study was to examine what kinds of extrinsic factors underlie the opinions expressed in Internet discussion forums on experiences of PE in Finnish schools.

Research design: The data for this research were collected from open Internet discussion forums during a randomly chosen week in April 2007. Using qualitative content analysis all the messages (total $n=356$ ) from nine forums were grouped into positive, both positive and negative, and negative messages. The messages were divided into smaller segments such as paragraphs, sentences or even words, and labelled opinions (total $n=652$ ).

Data analysis: Based on Carlson's model, these opinions were further grouped into intrinsic and extrinsic factors. This study concentrated on the extrinsic factors behind the opinions, as these can more easily be influenced by pedagogical developments. Six extrinsic factors were identified: teacher's personality and behaviour, curriculum, assessment, class environment, facilities and equipment, and out of school influences and other factors.

Findings: The results showed clearly that of the total of extrinsic factors only $8 \%$ were in the category of positive opinions and up to $61 \%$ in the category of negative opinions. The findings revealed that the teacher plays a crucial role in students' enjoyment of $\mathrm{PE}$, as is indicated by the fact that the personality and behaviour of the teacher was mentioned the most often ( $40 \%$ of all opinions). Almost every fourth opinion concerned the class environment. In the third place, accounting for $16 \%$ of opinions, were issues related to the curriculum.

Conclusions: Based on the results of the study, we conclude that more focus is needed on the pedagogical and emotional aspects of the learning environment. In PE teacher training it should be ensured that all future teachers have good socio-emotional skills and tools for creating a safe class environment. Teachers also need to widen their understanding on the strong role of emotions and experiences, as these can include humiliation and shame.

Keywords: physical education; experiences; extrinsic factors; Internet discussion forums

*Corresponding author. Email: kirsti.lauritsalo@jyu.fi

(C) 2013 Association for Physical Education 


\section{Introduction}

Physical education is a subject that generates strong feelings and emotions. A number of studies have found that PE has been reported by many students as their favourite subject (Carlson 1995; Dyson 2006; Groves and Laws 2000; Rikard and Banville 2006; Subramaniam and Silverman 2007). PE experiences are often described positively. However, some students report negative experiences of PE. In Carlson's (1995) article 'we hate gym', the author listened to the voices of alienated students. In her analysis of the literature, she identified some of the factors that may contribute to alienation: boredom, repetition, lack of meaningful work, teacher behaviour and a competitive class environment. In her alienation-non-alienation model, extrinsic factors (teacher personality and behaviour, curriculum, class environment and out-of-school influences) as well as intrinsic factors (ability, self-esteem and student beliefs) combined to yield the meaning the classes have for students (Carlson 1995). Earlier research that listened to the voices of the writers in Internet discussion forums relating to PE (Lauritsalo, Sääkslahti, and Rasku-Puttonen 2012) showed that negative experiences were more common in that environment than positive ones. We argue that it is important to know more about the extrinsic and intrinsic factors that underlie these experiences and learn from them for the benefit of future teacher education.

\section{Extrinsic factors}

The extrinsic factors mentioned above give an interesting perspective on PE experiences. Since physical education is so intensely personal, extrinsic factors are things that a person can blame, put aside, focus hate towards, and underrate. One extrinsic factor that emerges very clearly in relation to PE experiences is the teacher (Carlson 1995). Armour (2010) crystallizes the issue by stating that each teacher matters. Teachers have huge possibilities to influence the experiences students have in schools (Siedentop and Tannehil 2000). Strean (2009) proposes that the personal characteristics of the instructor are one of the major factors that can contribute to making sport and PE more fun for students. Strean (2009) emphasizes that the 'personhood' of the instructor is more memorable than the way in which learning is structured. In his study (Strean 2009), positive adjectives describing the teacher include caring, involved, present, fair and individualized. Siedentop and Tannehill (2000) use adjectives like effective, engaged, motivated, skilled, competent, qualified and caring. Graham, Holt/Hale, and Parker (1998) write about a reflective teacher. In addition to all these positive attributes teachers' social and emotional understanding and interaction skills are important (Graham 2008; Rink 2010). Cothran and Kulinna (2007) suggest that teachers need time and skills to build personal relationships with students: by caring and respecting students, teachers could avoid misbehaviour.

Following Carlson's model, the second extrinsic factor after the teacher is the curriculum (Carlson 1995). Not all students like the same activities (Williams and Bedward 2001). Rikard and Banville (2006) found that most high school students like PE, the main reasons given being fun, liking sports in general and liking the activity offered. They continue that the most common reasons for disliking PE were dislike of the activity offered, too much teacher talk, too little playing time, and that it was boring. A boring lesson is an important cause of misbehaviour among students (Cothran and Kulinna 2007). Cothran and Ennis (1999) argued that traditional skill-based programmes do not meet the needs of the less active and less fit students. Also, the transition from primary to secondary school brings curricular changes that present students with a greater variety of activities and more skill-based learning (Dismore and Bailey 2010). Dismore and Bailey (2010) argue that 
this transition is experienced differently by different students depending on their earlier attitudes towards PE.

The third extrinsic factor is the class environment (Carlson 1995). According to Strean (2009), strategies that the teacher can draw on in seeking to create a safe learning environment include providing variety, fun, games and novelty, providing adequate rules and strategy and fostering flow. Pangrazi and Darst (1997) suggested that teachers should develop effective listening skills and refine their communication skills, i.e. improve teacher-student communication and instructional communication in order to create a safe and stimulating environment. In this context, students' emotional experiences related to the motivational climate are important (Liukkonen et al. 2010). Social aspects relevant to the classroom environment include the importance of particular friends (Dismore and Bailey 2010; Strean 2009). In this connection, the time as to when teachers group students is especially delicate (Berg 2010; Rink 2010). Negative experiences in PE lessons reported by Strean (2009) included humiliation, achieving excellence in a competitive setting, verbal abuse, elitism, too little time, a sense of futility, antipathy and fear. Fear of being observed or evaluated by others may cause discomfort (Hartmann et al. 2010). Siedentop and Tannehill (2000) discuss the problem of students abusing and disadvantaging other students and also teasing and embarrassing one another.

In addition to the factors highlighted by Carlson (1995), another important factor is assessment, including testing and evaluation (Hartmann et al. 2010; Trout and Graber 2009; Wrench and Garrett 2008). Experiences of fitness testing evoke feelings from pleasure to pain, depending on the student's ability level (Harris and Cale 2007; Trout and Graber 2009; Wrench and Garrett 2008). In addition to this, there is evidence to sugges that there is an increasing number of overweight pupils in every class (Mastrangelo, Chaloupka, and Rattigan 2008). Trout and Graber (2009) studied the perceptions of overweight students concerning their past and present experiences of PE. Negative perceptions included PE as of little benefit for them, inappropriate teaching practices and the desire to avoid being visible to one's peers. Being able to view each other's performances during fitness tests and aversion to running were especially pointed out as unpleasant issues. Hartmann et al. (2010) found that being overweight may be a risk factor for fear of negative evaluation. When Trout and Graber (2009) asked about life as an overweight person in the PE context, the overweight students responded with social concerns such as their appearance when changing in the locker room, how others perceive their skill levels, feeling self-conscious, and being accepted by their peers.

\section{Listen to students' voices}

It is important to listen to students' voices in the research as well as instructional context (Carlson 1995; Cothran and Kulinna 2007; Dyson 2006; Subramaniam and Silverman 2007). Earlier studies have listened to students' voices through surveys and questionnaires, interviews and the analysis of diaries and classroom observations. Seale et al. (2010) argue that data collected in this way can be affected by social pressure or the need to please interviewers or teachers, if participants have cause to believe that they may be identified. In this study, open discussion forums are seen as a further, non-traditional, possibility to listen to students' voices. The Internet offers one such forum for finding new viewpoints for research purposes. It is a forum where new ideas are expressed and exchanged on issues in a changing world. The various discussion forums that exist in cyberspace make it possible for people to express themselves through real or imaginative/fictitious messages (Markham 2007). Since the participants 
in these forums write under a pseudonym, it is impossible to be sure whether they are male or female, young or old, whether they have joined the forum using several pseudonyms or only one, and what their real motivation is for making their opinions public. It might be easier to express highly sensitive and even intimate thoughts on the Internet (Seale et al. 2010). In this study, we understood 'experience' to include all the feelings, emotions, affects, images, beliefs, attitudes, memories and opinions the writers revealed in discussion forums on their experiences of PE. Henceforth, we use the word opinion as an overarching term for all of these.

\section{Purpose of the study}

The purpose of this study was to examine what kinds of extrinsic factors underlie opinions expressed in Internet discussion forums on experiences of PE in Finnish schools. In particular what is the role of the teacher, class environment, curriculum and assessment in these opinions? It is hoped that the results will be of practical value in PE teacher training in helping educators to ensure that all future teachers have good socio-emotional skills and tools for creating a safe class environment.

\section{Methods}

\section{Research design}

The data for this study were collected from Internet discussion forums during a randomly chosen week in April 2007. During the weeks before that date nothing in particular had happened in Finland to prompt any special reason to motivate discussion of PE. The data were collected using a Google ${ }^{\mathrm{TM}}$ search engine. Via a Google ${ }^{\mathrm{TM}}$ search with the broad term ' $\mathrm{kou}$ luliikunta' ['school PE' in Finnish], the first 200 hits included nine discussion forums. The first forum was the 31 st hit. The pages before that consisted of, e.g. different links to the PE curriculum in municipalities, various symposia and research results. The succeeding forums were found in $35 \mathrm{th}, 57 \mathrm{th}, 77 \mathrm{th}, 90 \mathrm{th}, 94 \mathrm{th}, 95 \mathrm{th}, 123 \mathrm{rd}$ and $197 \mathrm{th}$ place among these 200 hits. Since no additional criteria were set, other than the above, these Web forums represented a variety of areas, including discussions on animal rights (www. oikeuttaelaimille.net), junior football (www.nappulafutis.com), health (www.myartic.net), being overweight (www.terhi.net, http://chat.yle.fi) and memories of sports in school (http://ranneliike.net; http://chat.yle.fi; http://demi.fi,; http://keskustelu.suomi.24.fi). All nine forums were selected, numbered from one to nine and analysed further. The forums contained between 11 and 150 messages varying in length. All these messages in their original form were taken into consideration in this study. Altogether the nine discussion forums yielded 450 separate messages.

\section{Data analysis}

Using qualitative content analysis (Patton 2002), which involves reading and re-reading, the messages several times, four groups were clearly identified. If no negative comments about PE were contained in the message, it was categorized as 'Positive' and if the message contained no positive comment it was categorized as 'Negative'. If the message included a single positive comment while the rest was negative - or vice versa - it was categorized as 'Both positive and negative', later called 'Both' for short. The fourth group was labelled 'Other'. The messages in this fourth group included, for example, 
messages about eating and being overweight, smoking and other school subjects. After reading the messages in the 'Other' group more closely, this group was discarded because it did not directly relate to the topic of this research. This left 356 messages to be analysed further. To ensure reliability, the data were coded twice and in case of unclear or ambiguous messages our research team classified them as a team in order to avoid subjectivity. A detailed description of the categorization process is given in Lauritsalo, Sääkslahti, and Rasku-Puttonen (2012).

Next, the messages were analysed in greater depth. Depending on its length, a single message could contain several sentences, opinions and meanings. For this reason, the messages were divided into smaller segments such as paragraphs, sentences or even words. These segments, the research units, were termed 'Opinions' (total $n=652$ ).

All the 'Positive', 'Both' and 'Negative' 'Opinions' were grouped into intrinsic and extrinsic factors on the basis of Carlson's (1995) alienation-non-alienation model. This model, which has already been adapted for PE, seemed to be suitable for grouping 'Opinions' according to intrinsic and extrinsic factors. The rest of the model was not applied in this study.

This article concentrates on extrinsic factors as these had a particularly important role in the 'Opinions'. Moreover, extrinsic factors are something that can be influenced and modified, for example in pedagogical decisions, in specifying content in teacher education and changing the basis of PE.

In this study, the definition of extrinsic factors was enlarged from that in Carlson's (1995) original model. Re-reading the 'Opinions' several times revealed two new items: assessment, and facilities and equipment. Therefore, the six categories were:

(1) teacher's personality and behaviour, including liking or disliking the teacher, his/ her behaviour, the possibility for students to choose during lessons

(2) curriculum, including the wide/narrow range of different sports, the number of lessons per week, different sporting occasions in the school or with other schools, the size of the class, and PE as a compulsory subject

(3) class environment, including supportive/depressive feelings

(4) out-of-school influence and other factors, where the family and coaches were involved

(5) assessment, including grades in reports, rating and testing

(6) facilities and equipment, such as cross-country skis and skates, balls, and different kinds of gyms and dressing rooms

\section{The Internet as a research tool}

The Internet can be seen as a form of cultural production where people build virtual personas and social images for themselves and others (Bassett and O'Riordan 2002). In line with other researchers (Bruckman 2002), we regard the Internet as a social environment for publishing one's thoughts and feelings. We also assume, like Pitts (2004), that the web forums we research are 'truthful' (Hine 2000), and that the issues the writers raise are real for themselves. In our data, the 365 messages were posted by 239 different pseudonyms. Trolls (Tepper 1997), seeking to disrupt these forums with provocative messages about school PE, did not seem to be present. This was not, however, empirically verified and must thus be considered a limitation of this study. The ethics of online research depend on the nature of the research and on the target group (Bassett 
and O'Riordan 2002). In this study, the data were collected from open forums, which are available to everyone, whether as a subscriber or reader. Discussions and opinions exist in these open forums independently of research purposes. Therefore, no approach towards the forums' operators for permission to undertake the study was considered necessary. The topic of our research, school PE, was neither confidential nor private. Among the nine forums only two (animal rights and junior football) could be considered as primarily intended for a more limited audience, although they too were openly accessible. By chance, the selected forums were discussing PE during that particular week. No claims about the writers' off-line identities can be made. The same pseudonyms might have been used elsewhere (Bruckman 2002). For this reason, in this report, all the pseudonyms are referred to by code numbers.

\section{Results}

The results of this study revealed the experiences of PE in Finnish schools by the writers in the studied Internet discussion forums. Of the total $(n=652)$ 'Positive opinions' accounted for $11 \%$, 'Both positive and negative' for $34 \%$ and 'Negative opinions' for $55 \%$, and they were all categorized into either intrinsic $(38 \%, n=247)$ or extrinsic $(62 \%, n=405)$ factors. Table 1 shows how the six categories of extrinsic factors were distributed among the three groups ('Positive', 'Both' and 'Negative') of 'Opinions'.

Table 1 shows clearly that no one factor was common to all the 'Opinions'. Of the total of extrinsic factors, only $8 \%$ occurred in the group of 'Positive opinions' whereas $61 \%$ were found in the 'Negative' group. The six categories of extrinsic factors were fairly evenly distributed in the group of 'Positive opinions'. Within the group of 'Negative opinions', however, there was a wide variation.

The analysis clearly revealed that the teacher plays a crucial role in students' enjoyment of PE; the personality and behaviour of the teacher was the most often mentioned extrinsic factor ( $40 \%$ of all 'Opinions'). Almost every fourth 'Opinion' brought up the class environment. In the third place ( $16 \%$ of 'Opinions') were issues related to the curriculum. The identification of these three factors supports earlier findings (Cothran and Ennis 1997; Phillips 2011; Subramaniam and Silverman 2007).

The following results and excerpts are given in order of frequency (Table 1). All the writers behind the messages referred to in this study were coded such that the first digit indicates the discussion forum (listed earlier at the top of page 9) and the second the running number of the message (e.g. $(3,10)$ came from the MyArtic.Net forum and was the 10th

Table 1. The percentage distribution of the six extrinsic factors in the 'positive', 'both positive and negative', and 'negative' groups of 'opinions'.

\begin{tabular}{lcccc}
\hline Extrinsic factors & 'Positive' \% & 'Both' \% & 'Negative' \% & All \% \\
\hline Teacher's personality and behaviour, $n=163$ & 2 & 16 & 22 & 40 \\
Class environment, $n=96$ & 2 & 5 & 17 & 24 \\
Curriculum, $n=64$ & 2 & 5 & 9 & 16 \\
Assessment, $n=35$ & 1 & 3 & 5 & 9 \\
Facilities and equipment, $n=34$ & 0 & 2 & 6 & 8 \\
Out-of-school influence and other & 0.5 & 0.5 & 2 & 3 \\
$\quad$ factors, $n=13$ & $8(n=34)$ & 31 & 61 & 100 \\
Total $(n=405)$ & & $(n=126)$ & $(n=245)$ & \\
& & & &
\end{tabular}


message in that forum). The original messages have been translated from Finnish into English for this report by a native speaker of English.

\section{Teacher's personality and behaviour}

In the group of 'Positive opinions', the teacher and his/her behaviour were not emphasized, but in the group 'Both', almost every second 'Opinion' dealt with the teacher. In the 'Negative' group, the role of the teacher was also significant, occurring in about every third 'Opinion'.

Good PE teachers do exist, but such pearls are rare $(3,10)$

... but anyway the teacher is in a pretty important position during PE classes - if the teacher is a real dickhead I don't believe your attitude can be anywhere near positive $(8,77)$

Teachers' personalities were described with reference to age and appearance, professional ability, how sporty he/she was and personal characteristics that were considered important. The impact of the curriculum on a pupil's learning is determined by teachers and the ways they put it into practice. One teacher during a life-long career delivers around 30,000 PE lessons and during them meets about 100,000 pupils (Armour 2010). Seen thus, it is self-evident that the teacher's role is important. In the 'Opinions', teachers were nice and fair, flexible and understanding and did not have any favourite pupils (cf. Strean 2009). Or teachers were described as old and repulsive: 'an old bird close on sixty, very traditional, always trying to act young' $(7,16)$. According to the data, the teachers' professional skills varied between very skilled and miserable (Strean 2009). In the group 'Both', the descriptions of the teachers' character and relationship towards the pupils ranged from 'the nicest in the whole world' $(8,112)$ to 'sadistic war-mongering slave driver' $(4,19)$. In most 'Opinions', the feelings towards teachers were not empathic at all: 'complete Nazi' $(4,24)$, 'fucking shithead' $(8,77)$ or 'totally irritating cow' $(8,6)$.

Teachers' behaviour was included in the writers' 'Opinions' whether they approved or did not approve of it. The writers wrote about their teachers' practical skills in different sports and how teachers joined in the physical activity, their attitude and support towards all the students - both good and less talented ones, and their ability to be fair and to listen to a pupil. Teachers' social and emotional understanding and interaction skills (Graham 2008; Rink 2010) were highlighted in several 'Opinions'. Some writers felt it was important that teachers took time to learn students' names, thereby demonstrating care for the individual (Owens and Ennis 2005; Rink 2010).

... she always listened to us, took part herself in PE and gave us encouragement $(8,43)$

the gym teacher in the lower comprehensive was this uptight, sports-mad young woman, who really couldn't muster any understanding for anyone who wasn't as keen on sport as she was. The PE classes in the lower comprehensive were a real pain. From those days in the lower comprehensive I also still remember the swimming lessons, which were absolutely terrible: they left you roughly with the feeling that the pupils were simply thrown into the pool and instructed raucously to sink or swim. $(7,13)$

The extent to which teachers were part of the group and joined it, especially when moving outside the school to the sports ground was frequently commented on. Some writers felt that the teacher was an outsider and lazy: 'even though it was pelting down, 
the class had to go for a run. The teacher himself drove to the halfway point, and just sat in his car drinking hot chocolate. Then he opened the car window and gave us the OK sign, now you can head back to the school ...' $(5,26)$

The 'Negative opinions' attacked the teacher's teaching skills. Waiting in a queue while one pupil was performing and the others watching was strongly pointed out. Some writers felt that they were not taught, only made to perform: 'There's no teaching of basic skills, no guidance given during the lessons. To put it briefly, during the lessons we stand in Indian file or in a line, or then there's total chaos' $(2,4)$. Writers' perceptions about their involvement in the decision-making processes varied widely. Possibilities for writers to choose what was taught in their PE lesson or during the term were very few. In the main, the writers complained about not being able to influence PE: '... it was really shitty that the teacher never listened to the pupils' wishes, we always had to follow blindly the plan drawn up by some irritable bastard (maybe the teacher himself?) ...' $(7,70)$

Above all, very strong feelings of compulsion and humiliation were mentioned in most of the 'Opinions'. As Constantinou, Manson, and Silverman (2009) argue, teachers should offer all students the possibility to experience competition, success and achievement without serious injury or humiliation. Despite their fear, some writers were afraid the teacher would force them to do the task. In some 'Opinions', the writers complained how the teacher declared the results aloud and compared good performances with poor Instead of supporting the students, the teacher's reaction was to join the rest of the class in laughing at failure. These writers felt that their last remnant of self confidence and belief in oneself was eroded by the teacher. Also inappropriate was the way teachers treated students regarding showering.

the teacher's brainwaves included forcing everybody into the shower on the pretext that he had personally witnessed how people developed a really nasty mould in their armpits because they used a deodorant without bothering to shower. $(5,46)$

\section{Class environment}

Among the extrinsic factors, class environment was in second place in the writers' 'Opinions'. The existence of a supportive or depressive atmosphere was a common topic when talking about the class environment (Strean 2009). Feeling good during PE classes was mentioned in the context of telling about teachers' acceptance of students in PE lessons and also outside them. Some writers had preferred the atmosphere during PE lessons in primary school, some just the opposite. Pressure to perform well seemed to start very early.

In the lower comprehensive [7-12 yrs] PE lessons were not to my liking, because the general feeling in the class was that if you're not good at PE then you're fat, dumb and lazy. $(7,73)$

Writers were vociferous about the unpleasant atmosphere in their PE classes: The worst thing I remember was the dispiriting atmosphere of compulsion' $(7,1)$. Criticism was also levelled at a non-existent team spirit: 'In school PE a load of bullshit is talked about team spirit and suchlike, but in reality it's sheer hell where people humiliate each other' $(8,146)$.

Many writers seemed to have felt better in their earlier school years; as time went by their self confidence had been eroded along with negative feedback from their teachers and classmates. When a writer was the butt of criticism she/he really felt a failure and 
rejected. In PE, the writer no longer knew what to do in this 'oppressive mental hell' $(8,7)$ Bullying during PE lessons, and especially after the lesson in the dressing room, was typical. And when such bullying continued week after week and month after month, it left an unforgettable imprint on the growing young person. These results support findings from related research (Morgan and Hansen 2008; Trout and Graber 2009).

When my team loses at floorball because I've cocked up, then in the gym everything's still quite $\mathrm{OK}$, but in the changing room if not before people start looking down their noses at me and levelling silent (or even verbal) accusations. I don't need telling that I am clumsy, stupid and in terrible shape! In addition to all that I'm twelve years old and my self-esteem is at an absolute zero. $(8,134)$

The most often mentioned single reason $(n=33)$ for negative experiences of the PE class environment $(n=68)$ seemed to be the moments when the students were divided into teams or groups. This result has also commonly been found in earlier studies (Berg 2010). Typically, the writers referred to selection by the team captain - the way two pupils were chosen to select one pupil at a time to be in his/her team. The best and talented or 'best friends' were chosen first. The feelings of those left to be last were of extreme humiliation and shame. Also the 'one-two-one-two ...' method of division was not felt to be fair There 'best friends' changed places to be able to be on the same side. One writer had located the core of the matter: 'More than the teacher it was my classmates who exerted an influence. At the end of the day the teacher is pretty powerless to affect the class's internal hierarchies. After all, they can't be changed simply by altering the way in which teams get picked.' $(4,29)$ Most of these 'Opinions' expressed how the writers had felt rejected, lost, hated and worthless in their classmates' eyes.

The feeling of coming last is so indescribably humiliating, you just have to swallow hard and stare superciliously at the wall as if you're not bothered in the slightest. $(8,8)$

\section{Curriculum}

The curriculum was the third most common extrinsic factor mentioned in the writers' 'Opinions'. The most negative attitudes were expressed towards apparatus gymnastics, volleyball, skiing, orienteering, swimming and athletics. 'Opinions' about the repertoire of the different sports available at different school levels varied. One writer stated, ‘... In the lower comprehensive PE took many forms, now that I'm starting to recall more precisely. In the upper comprehensive it's become dull, something that keeps repeating itself' $(2,10)$, while another wrote just the opposite: '. . In the upper comprehensive PE was already a bit more varied' $(2,13)$. These findings have also emerged in previous research (Dismore and Bailey 2010; Rikard and Banville 2006).

In the autumn Finnish baseball, as the weather worsened basketball and volleyball, in winter ice hockey, in the spring apparatus gymnastics and in early summer football. That was about it throughout comprehensive school. Well, perhaps once we went orienteering and visited the swimming hall in the neighbouring city. The joy of physical recreation was killed successfully by school PE. $(4,7)$

The number of lessons per week varied and some writers would have preferred more PE lessons: four a week was frequently mentioned. When writing about single or double lessons, the writers preferred double because '... single lessons are no use because at the 
start of each lesson about 10 minutes is wasted changing clothes etc.' $(2,12)$. Also they had paid attention to the fact that 'PE lessons in schools are often used for various events and unimportant happenings' $(2,3)$.

One special sports day a term was endorsed by several writers. But competitions within one's own school or against other schools were not liked. Athletics and skiing competitions were, especially, experienced as unpleasant.

The compulsory annual skiing competition in the lower comprehensive. It was awaited each year with dread and then everyone did their absolute damnedest to ensure they didn't come in last. Really encouraging ... (7,57)

$\mathrm{PE}$ as a compulsory subject inspired some writers: 'The boring, normal stuff is just what it says on the label' $(3,13)$ was a typical comment. The feeling that the optional PE was more enjoyable was strong: 'Compulsory PE courses were pretty run-of-the-mill stuff, but in elective courses we really got to do something challenging' $(7,27)$.

\section{Assessment}

The topic of assessment included grades in reports and rating/testing during the PE lesson. Most of the 'Opinions' were against the numerous grades given in reports. Joy and the willingness to try were suppressed because of grading and fear of negative evaluation (Trout and Graber 2009). The reasoning behind the evaluations seemed to be unclear to some writers: '. . A Aha, I tried my best and got a seven, well, not much point in even trying then' $(8,73)$

Some writers pointed out that the testing and measurement filled their PE lessons in many sports. In athletics, running, fitness tests, swimming and sit-ups, all the results given in percentages for interstudent comparison, or simply published, was frustrating. Also if a student managed well in a test, he/she was introduced to the local competition which was not seen as a comfortable experience. Writers told about having underachieved on purpose to avoid participation in these competitions. These results support earlier findings (Hartmann et al. 2010; Wrench and Garrett 2008).

... in everything you had to look at the results tables and see how poorly you were doing. Those damned tables certainly killed off all the joy of PE. It would have been all right if it hadn't been purely a matter of chasing results. $(7,52)$

\section{Facilities and equipment}

In this study, comments regarding facilities and equipment included balls and the material they were made of : '. . do I even have the chance to refuse to take part in PE for ethical reasons? I mean, like, choosing to do press-ups while the others are playing something that involves leather ...' $(1,9)$. Fear of the ball and ballgames was also expressed: '... Anyway the ball was really hard and it was frightening trying to catch it with an ill-fitting mitt. Let alone when someone threw it directly towards you' $(6,13)$. Writers complained about the gyms or the normal classrooms used for PE, the equipment in the gyms and the shower rooms. Experiences of the primary school gyms were bad. Normal classrooms were used after pushing the desks aside. The rooms were too small and low for games. Splinters were caught from the floors: 'Primary school was like that, feet full of splinters and freezing water in the showers' $(7,27)$. These findings are consistent with those of previous research (Dismore and Bailey 2010) 
Winter sports lessons and the angst associated with carrying skis or skates attracted much comment. The traumas of cross-country skiing were not related so clearly to the skiing itself but the uncomfortable business of transporting the skis on the buses between home and school: 'I hate skiing because you have to haul the equipment a million kilometers to school and from there over to the ski trail' $(8,33)$. Not only the skis but also the skates were often old and also the weather was either too cold or the lesson took place after a snowstorm and the pupils had to make their own tracks.

\section{Discussion and conclusions}

Our aim was to examine what kinds of extrinsic factors underlie the 'Opinions' expressed in Internet discussion forums on experiences of PE in Finnish schools. The main finding was that the teacher plays a crucial role in students' perceptions of their experience of PE. The teacher's personality and behaviour were the topics most often mentioned by the writers. Almost every fourth 'Opinion' dealt with the class environment, where a supportive or a depressing atmosphere was the most common topic. In the third place were issues related to the curriculum, where 'Opinions' varied widely. Thereafter in order of frequency were issues concerning assessment, and facilities and equipment. 'Opinions' concerning out-of-school influences and other factors were few and did not add anything to this study. A substantial body of research exists on students' dislike of assessment (Hartmann et al. 2010; Wrench and Garrett 2008). In our study this also emerged, but not as strongly as might have been expected. A surprising detail, however, was the discussion (in $17 / 23$ messages in the forum related to animal rights) about leather and nature and how these affected the writers' experiences of PE, introducing a whole new reason for disliking PE. A noteworthy aspect of this study was the way the writers gave free rein to their emotions, sometimes expressing themselves very strongly. While results are in line with those of earlier research (Dismore and Bailey 2010; Phillips 2011; Rikard and Banville 2006), the feelings bound up with the writer's experiences are more clearly foregrounded with the method used in this study. It is important for teachers to be aware of strongly expressed 'Opinions' in order to be able to understand students for whom PE evokes negative feelings. It seems to be easier for such feelings to be given expression anonymously online (Ransom et al. 2010; Seale et al. 2010).

Good 'personhood' in a teacher can be described by positive adjectives like caring, involved, present, fair and individualized (Strean 2009). The same themes were found in this study. These results raise the issue of whether selection procedures for PE teachersto-be should not take these abilities more into account. In our study, teaching skills received negative feedback. Teacher education in PE should also pay more attention to this aspect of pedagogy (Kårhus 2010). The same topics arise time after time: waiting in a queue, not taught but only made to perform, not being able to influence what goes on in PE, and worst of all feeling forced to perform and enduring humiliation following failure (Berg 2010). For some people, PE encapsulates their unhappiest memories of school. It is important for a teacher to understand in what kinds of situations a student can feel humiliation in order to avoid them. As good PE students at school themselves, how can PE teachers learn to understand those less fortunate? No doubt these issues should be included in teacher education curricula, but nevertheless something more needs to be done if negative feelings about $\mathrm{PE}$ are to be avoided in the future. The focus in teacher training should include general education and PE didactics, paying attention to ways of turning negative attitudes towards PE into positive ones. Teachers need to widen their understanding of the strong role of emotions and experiences, as these can include feelings of humiliation and shame. 
The class environment and the relationships between the students present teachers with enormous challenges. The field of sport psychology has helped us to understand teachers' possibilities for coping strategies during PE lessons (Liukkonen et al. 2007). However, when talking about the class environment the role of the other students is also important (Dismore and Bailey 2010; Strean 2009). The situation in the changing room is also important (Trout and Graber 2009). Schools should make it possible for the teachers to control these out-of-the-gym situations in order to guarantee students' mental safety and avoid bullying behind their backs. In the class environment the teacher possibly has less influence than the students. This cannot be changed simply by different methods of dividing students into teams (Berg 2010). The importance of friends (Strean 2009) is crucial in these situations. Rink (2010) argues that teachers often fail to take advantage of these situations between rival captains. Perhaps providing variety in different sports, generating fun in doing activities, offering different games and individual tasks as well as novelty could help students to find PE classes more enjoyable and create a better atmosphere during classes (Rink 2010; Liukkonen et al. 2010). On the basis of our results we suggest that more focus on the pedagogical and emotional aspects of the learning environment is needed. In PE teacher training it should be ensured that all future teachers have the willingness and understanding to take on a strong role as an educator, good socio-emotional skills and the tools for creating a safe class environment (Armour 2010; Bailey et al. 2009). Teachers should also pay attention to the social and emotional knowledge of the students (Ferry, McCaughtry, and Hodges Kulinna 2011). The fear and experience of being embarrassed and humiliated can leave a permanent imprint on the individual. In PE one cannot hide away, meaning that physically one is always present and on stage in front of others. These are strongly experienced moments and should be avoided. They are precisely the kinds of experiences that emerged in the discussion forums examined in this study.

\section{Limitations}

Certain clear limitations of this study should be acknowledged. In the results we have to take into consideration that we do not know who the writers are and when they experienced the feelings they write about. Since there were many $(n=239)$ different pseudonyms posting these messages $(n=356)$, we assume that they reflect the situation of more than just a few persons. In some studies researchers investigate the subject in a specific forum specially set up for the purpose of their research. This was not the case in this study. Discussions and opinions exist in forums independently of research purposes. Data collected in this way are totally unaffected by social pressure or the need to please interviewers or teachers (cf. Seale et al. 2010). For this reason all the facts about the writers and their background remain unknown. However, there may be an unwritten imperative in forums to compete with previous writers and make one's experiences sound even worse or better than theirs (Hagger et al. 2009). It may be that the Internet encourages more forthright expression and that negative examples fuel the effects of other writers. Also, provocative messages (trolling) might be posted with the express purpose of inciting strong reactions (flaming) from people (Millard 1997; Tepper 1997).

How PE is experienced at school is important for the future sport and health behaviour of the student him/herself (Trudeau and Shephard 2005; Yli-Piipari 2011). Therefore, today's schools and the prevailing physical education culture are under strong pressure to produce positive student experiences. The school has been given the task of building the student's self-esteem and a positive physical self- concept through favourable PE experiences and of encouraging cooperativeness and positive future sport and health 
behaviour (Finnish National Core Curriculum for Basic Education 2004). These aspects are in line with the international targets of physical education (NASPE 2004). However, there continue to be students who do not achieve these targets. A closer look at the curriculum and perhaps updating it to include the needs of today's students' could increase their dedication to PE.

\section{References}

Armour, K. 2010. "The Physical Education Profession and its Professional Responsibility. . .or... Why '12 Weeks Paid Holiday' will Never be Enough.” Physical Education and Sport Pedagogy 15 (1): $1-13$.

Bailey, R., K. Armour, D. Kirk, M. Jess, I. Pickup, R. Sandford, and the BERA. 2008. "The Educational Benefits Claimed for Physical Education and School Sport: An Academic Review." Research Papers in Education 24 (1): 1-26.

Bassett, E. H., and K. O'Riordan. 2002. "Ethics of Internet Research: Contesting the Human Subjects Research Model." Ethics and Information Technology 4 (3): 233-247.

Berg, P. 2010. "Group Boundaries and Hierarchies: Ethnographic Study of Physical Education in Secondary School." Social Psychological Studies 22, PhD diss., University of Helsinki.

Bruckman, A. 2002. "Studying the Amateur Artist: A Perspective on Disguising Data Collected in Human Subjects Research on the Internet." Ethics and Information Technology 4 (3) $217-231$.

Carlson, T. 1995. "We Hate Gym: Student Alienation from Physical Education." Journal of Teaching in Physical Education 14 (4): 467-477.

Constantinou, P., M. Manson, and S. Silverman. 2009. "Female Students' Perceptions about GenderRole Stereotypes and their Influence on Attitude Toward Physical Education.” Physical Educator 66 (2): $85-96$

Cothran, D. J., and C. D. Ennis. 1997. "Students' and Teachers' Perceptions of Conflict and Power." Teaching and Teacher Education 13 (5): 541-553.

Cothran, D. J., and C. D. Ennis. 1999 “Alone in a Crowd: Meeting Students' needs for Relevance and Connection in Urban High School Physical Education." Journal of Teaching in Physical Education 18 (2): 234-247.

Cothran, D. J., and P. H. Kulinna. 2007. "Students' Reports of Misbehavior in Physical Education." Research Quarterly for Exercise and Sport 78 (3): 216-224.

Dismore, H., and R. Bailey. 2010. "'It has been a Bit of a Rocky Start': Attitudes Towards Physical Education Following Transition." Physical Education \& Sport Pedagogy 15 (2): 175-191.

Dyson, B. 2006. "Students' Perspectives of Physical Education." In The Handbook of Physical Education, edited by D. Kirk, D. Macdonald, and M. O'Sullivan, 326-346. London: Sage.

Ferry, M., N. McCaughtry, and P. Hodges Kulinna. 2011. "Social and Emotional Pedagogy: Rhythm and Junctures.” Journal of Teaching in Physical Education 30 (1): 13-30.

Finnish National Core Curriculum for Basic Education. 2004. http://www.oph.fi/english

Graham, G. 2008. Teaching Children Physical Education. Becoming a Master Teacher. Champaign, IL: Human Kinetics.

Graham, G., S. A. Holt/Hale, and M. Parker. 1998. Children Moving. A Reflective Approach to Teaching Physical Education. 4th ed. Mountain View, CA: Mayfield Publishing Company.

Groves, S., and C. Laws. 2000. "Children's Experiences of Physical Education.” European Journal of Physical Education 5 (1): 19-27.

Hagger, M., C. Wood, C. Stiff, and N. Chatzisarantis. 2009. "The Strength Model of Self Regulation Failure and Health-Related Behaviour." Health Psychology Review 3 (2): 208-238.

Harris, J., and L. Cale. 2007. "Children's Fitness Testing: A Feasibility Study." Health Education Journal 66 (2): $153-172$.

Hartmann, T., L. Zahner, U. Pühse, S. Schneider, J. J. Puder, and S. Kriemler. 2010. "Physical Activity, Bodyweight, Health and Fear of Negative Evaluation in Primary School Children." Scandinavian Journal of Medicine and Science in Sports 20 (1): 27-34.

Hine, C. 2000. Virtual Ethnography. London: Sage.

Kårhus, S. 2010. "Physical Education Teacher Education on the Education Market - Who's Defining What Physical Education Teachers Need to Know?" Physical Education and Sport Pedagogy 15 (3): $227-241$. 
Lauritsalo, K., A. Sääkslahti, and H. Rasku-Puttonen. 2012. "Student's Voice Online: Experiences of PE in Finnish Schools." Advances in Physical Education 2 (3): 126-131.

Liukkonen, J., V. Barkoukis, A. Watt, and T. Jaakkola. 2010. "Motivational Climate and Students' Emotional Experiences and Effort in Physical Education." The Journal of Educational Research 103 (5): 295-308.

Liukkonen, J., Y. Vanden Auweele, B. Vereijken, D. Alfermann, and Y. Theodorakis, eds. 2007. Psychology for Physical Educators. 2nd ed. Champaign. IL: Human Kinetics.

Markham, A. N. 2007. "The Internet as Research Context." In Qualitative Research Practice, edited by C. Seale, G. Gobo, J. Gubrium, and D. Silverman, 328-344. London: Sage.

Mastrangelo, A., E. Chaloupka, and P. Rattigan. 2008. "Cardiovascular Fitness in Obese Versus Nonobese 8-11-year-Old Boys and Girls." Research Quarterly for Exercise and Sport 79 (3): $356-362$.

Millard, W. B. 1997. "I Flamed Freud. A Case Study in Teletextual Incendiarism." In Internet Culture, edited by D. Porter, 145-159. New York: Routledge.

Morgan, P., and V. Hansen. 2008. "The Relationship between PE Biographies and PE Teaching Practices of Classroom Teachers." Sport, Education and Society 13 (4): 373-391.

National Association for Sport and Physical Education. 2004. Moving into the Future: National Standards for Physical Education. Reston: NASPE.

Owens, L., and C. Ennis. 2005. "The Ethic of Care in Teaching. An Overview of Supportive Literature." Quest 57: 392-425.

Pangrazi, R. P., and P. W. Darst. 1997. Dynamic Physical Education for Secondary School Students 3rd ed. Needham Heights, MA: Allyn and Bacon.

Patton, M. 2002. Qualitative Research \& Evaluation Methods. Thousand Oaks, CA: Sage.

Phillips, S. R. 2011. "Upper Elementary School Students' Attitudes and Perceptions Toward Physical Education." UMI 3451687 Dissertation Publishing, ProQuest LLC, Ann Arbor, MI.

Pitts, V. 2004. "Illness and Internet Empowerment: Writing and Reading Breast Cancer in Cyberspace." Health 8 (1): 33-59.

Ransom, D. C., J. G. La Guardia, E. Z. Woody, and J. L. Boyd. 2010. "Interpersonal Interactions on Online Forums Addressing Eating Concerns." International Journal of Eating Disorders 43 (2): $161-170$.

Rikard, G. L., and D. Banville. 2006. "High School Students Attitudes about Physical Education." Sport, Education and Society 11 (4): 385-400

Rink, J. 2010. Teaching Physical Education for Learning. New York: McCraw-Hill.

Seale, C., J. Charteris-Black, A. MacFarlane, and A. McPherson. 2010. "Interviews and Internet Forums: A Comparison of Two Sources of Qualitative Data." Qualitative Health Research 20 (5): 595-606.

Siedentop, D., and D. Tannehill. 2000. Developing Teaching Skills in Physical Education. 4th ed. California: Mayfield Publishing Company.

Strean, W. B. 2009. "Remembering Instructors: Play, Pain and Pedagogy." Qualitative Research in Sport and Exercise 1 (3): 210-220.

Subramaniam, P. R., and S. Silverman. 2007. "Middle School Students' Attitudes Towards Physical Education." Teaching and Teacher Education 23 (5): 602-611.

Tepper, M. 1997. "Usenet Communities and the Cultural Politics of Information." In Internet Culture, edited by D. Porter, 39-54. New York: Routledge.

Trout, J., and K. C. Graber. 2009. "Perceptions of Overweight Students Concerning their Experiences in Physical Education." Journal of Teaching Physical Education 28 (3): 272-292.

Trudeau, F., and R. J. Shephard. 2005. "Contribution of School Programmes to Physical Activity Levels and Attitudes in Children and Adults." Sport Medicine 35 (2): 89-105.

Williams, A., and J. Bedward. 2001. "Gender, Culture and the Generation Gap: Student and Teacher Perceptions of Aspects of National Curriculum Physical Education." Sport, Education and Society 6 (1): $53-66$

Wrench, A., and R. Garrett. 2008. "Pleasure and Pain: Experiences of Fitness Testing." European Physical Education Review 14 (3): 325-346.

Yli-Piipari, S. 2011. The Development of Students' Physical Education Motivation and Physical Activity: A 3.5-year Longitudinal Study Across Grades 6 to 9. Jyväskylä: University of Jyväskylä. 


\title{
INTERNETIN KESKUSTELUPALSTALLA KIRJOITETAAN KOULULIIKUNNASTA: "JA KAIKKI NÄKEE, KUN SÄ YRITÄT"
}

\author{
by \\ Lauritsalo Kirsti, Sääkslahti Arja \& Rasku-Puttonen Helena 2012 \\ KASVATUS 43 (3), 255-267.
}

Reproduced with kind permission by Suomen Kasvatustieteellinen seura. 
Internetin keskustelupalstalla kirjoitetaan koululiikunnasta: "Ja kaikki näkee, kun sä yrität"

Lauritsalo, Kirsti - Sääkslahti, Arja - Rasku-Puttonen, Helena. 2012. INTERNETIN KESKUSTELUPALSTALLA KIRJOITETAAN KOULULIIKUNNASTA:"JA KAIKKI NÄKEE, KUN SÄ YRITÄT". Kasvatus 43 (3), 255-267.

Tutkimuksen tarkoitus oli selvittää, minkälaisista koululiikuntaan liittyvistä tekijöistä kerrotaan internetin keskustelupalstoilla. Opetuksen kehittämiseksi ja aidon vuoropuhelun synnyttämiseksi oppilailla täytyy olla keinoja ilmaista vapaasti ajatuksiaan ja tunteitaan. Tutkimusaineisto kerättiin avoimilta keskustelupalstoilta viikolla 15 vuonna 2007 $\mathrm{Google}^{\mathrm{TM}}$-hakukoneen avulla hakusanalla "koululiikunta". Ensimmäiset 200 osumaa sisälsivät yhdeksän keskustelupalstaa, jotka kaikki analysoitiin. Laadullisen sisällönanalyysin avulla keskustelujen sisällöstä eroteltiin mielipiteet, jotka liittyivät kirjoittajaan itseensä liittyviin tekijöihin ( $\mathrm{n}=247)$ sekä kirjoittajan ulkopuolisiin tekijöihin $(\mathrm{n}=405)$. Tämä tutkimus rajattiin mielipiteisiin, joiden taustalla olivat kirjoittajaan itseensä liittyvät tekijät. Näistä lähes puolet $(\mathrm{n}=116)$ käsitteli sitä, kuinka kirjoittajat kokevat liikunnan. Aineiston analyysi toi esiin kielteisiä kokemuksia, jotka esitettiin verkossa hyvin tunteikkaasti. Vastenmielisyys koululiikuntaa kohtaan näyttää syntyvän voimakkaista kielteisistä kokemuksista. Tulosten perusteella voidaan korostaa emotionaalisten tilanteiden merkitystä koululiikunnassa. Siksi liikuntakasvatuksessa tulisi kiinnittää tähänastista enemmän huomiota pedagogisiin ratkaisuihin.

Asiasanat: koululiikunta, internetin keskustelupalstat, liikuntakokemusmalli, kirjoittajaan itseensä liittyvät tekijät 


\section{Johdanto}

Koulun liikuntatunneilla saadut kokemukset ovat pohjana sille, kuinka myönteisen tai kielteisen kuvan oppilas saa koululiikunnasta (Kirk 2005). Koululiikunnasta saatujen kokemusten on todettu vaikuttavan myös henkilön myöhempään liikunta-aktiivisuuteen (Carroll \& Loumidis 2001; Fox 1998; Trudeau \& Shephard 2005; Yli-Piipari 2011) ja fyysiseen itsetuntoon (Fox 1998, 2000; Biddle, Wang, Chatzisarantis \& Spray 2003). Tutkimusten mukaan koululiikunta koetaan pääosin myönteisesti. Useat aikaisemmat ulkomaiset (kyselykaavakkein, observoinnein ja haastatteluin toteutetut) sekä kotimaiset (pääasiassa kyselykaavakkein toteutetut) tutkimukset osoittavat, että koululiikunnasta pidetään ja liikunta on usein mainittu suosituimpana kouluaineena (esim. Dyson 2006; Nupponen, Penttinen, Pehkonen, Kalari \& Palosaari 2010; Palomäki \& Heikinaro-Johansson 2011; Rikard \& Banville 2006; Subramaniam \& Silverman 2007). Koululiikuntaan kohdistuu myös kielteisiä tunteita (Berg 2010; Carlson 1995; Morgan \& Hansen 2008; Trout \& Graber 2009).

Oppilaiden äänen kuunteleminen niin opetuksen kuin tutkimuksenkin näkökulmasta on haastavaa, mutta tärkeää (Cothran \& Kulinna 2007; Dyson 2006; Subramaniam \& Silverman 2007). Opetuksen kehittämiseksi ja aidon vuoropuhelun synnyttämiseksi oppilailla täytyy olla keinoja ilmaista tunteitaan ja ajatuksiaan. Tähän internet on avannut uusia mahdollisuuksia.

Internetin käyttö on jokapäiväistynyt. Tilastokeskuksen (2011) mukaan 76 \% suomalaisista 16-74-vuotiaista käyttää internetiä päivittäin tai lähes päivittäin, useampi kuin joka toinen useasti päivässä. Keskustelupalstoille kirjoittaa $45 \%$ naisista ja $44 \%$ miehistä (3 kk:n aikana, 16-74-vuotiaat, Tilastokeskus 2011). Internetin keskustelupalstalla kasvottomana esiintyminen antaa mahdollisuuden avautumiseen. Kirjoittajan persoonallisuuden voi "piilottaa" näytön taakse (Kangasniemi 2008; Markham 1998; Tapscott 2009), jol- loin arkaluonteisista, jopa intiimeistä asioista on helpompi puhua (Laukkanen 2007; Pitts 2004; Seale, Charteris-Black, MacFarlane \& McPherson 2010). Vahvat tunteet, pettymykset ja kokemukset synnyttävät voimakkaan tarpeen kirjoittaa, kertoa ja jakaa tuntemuksia muiden kanssa. Näyttää siltä, että kielteisten tunteiden purkaminen on helpompaa verkossa kuin esimerkiksi kasvotusten keskustelemalla (Ransom, La Guardia, Woody \& Boyd 2010; Seale ym. 2010). Tutkimusten mukaan internetin keskustelupalstoilla kirjoittavat henkilöt ovat aktiivisia emotionaalisen ja tiedollisen tuen antamisessa ja vastaanottamisessa (Laukkanen 2007; Ransom ym. 2010; Pitts 2004; Seale ym. 2010). Siksi on oletettavaa, että keskustelupalstoja tutkimalla ja analysoimalla voi löytyä sellaisia tekijöitä, joita muilla tutkimusmenetelmillä ei tavoiteta.

Tämän tutkimuksen tarkoitus oli selvittää, millaisena koululiikunta näyttäytyy internetin keskustelupalstoilla: millaisia kirjoittajaan itseensä liittyviä tekijöitä ja asioita mielipiteissä esiintyy sekä millaisia ajatuksia ja tunteita kirjoitetaan koululiikunnasta? Tässä kontekstissa, tämäntyyppistä aineistoa käyttäen, aihetta ei ole tähän mennessä aikaisemmin tutkittu.

\section{Liikuntakokemusmallin kuvaus taustatekijöistä}

Koulun liikuntakasvatuksen tavoitteena on liikunnallisesti aktiivisen elämäntavan synnyttäminen (NASPE 2004; POPS 2004), joka edellyttää myönteistä liikuntasuhdetta. Olennaisia siis ovat lasten saamat kokemukset liikunnasta (Fox 1998; Johansson, Heikinaro-Johansson \& Palomäki 2011; Kirk 2005). Jotta oppilaat saisivat mahdollisimman paljon hyviä ja mahdollisimman vähän huonoja liikuntakokemuksia, opettajien tulisi ymmärtää, miksi oppilas ajattelee tai kokee tietyllä tavalla. Foxin (1998, 2) kehittämä liikuntakokemusmalli (kuvio 1) auttaa ymmärtämään oppilaan näkökulmaa liikunnasta. Mallissa keskeisessä asemassa ovat yksilö ja hänen kokemuksensa.

Kokemus käsitteenä on hyvin laaja-alai- 
KUKA MINÄ OLEN? fyysinen ja psykologinen
MITÄ LIIKUNNASSA TAPAHTUU?

ginen

MITÄ AJATTELEN LIIKUNNASTA JA

MILTÄ SE MINUSTA TUNTUU?

nautinto ja palkkiot

pätevyyden kokemukset

luottamus

tunnetilat

MITÄ LIIKUNNASSA TEEN?

päätökset

omistautuminen ja sinnikkyys

motivaatio

suoritus

KUVIO 1. Liikuntakokemusmalli (Fox 1998, 2)

nen. Tässä yhteydessä ymmärrämme kokemuksen samoin kuin Perttula $(2009,149)$, jonka mukaan "kokemus on tajunnallinen tapa merkityksellistää niitä todellisuuksia, joihin ihminen on suhteessa. Tästä todellisuudesta olen käyttänyt nimitystä elämäntilanne. Kokemus on sitä, mitä elämäntilanne ihmiselle tarkoittaa". Liikuntakokemuksessa edellä mainittua elämäntilannetta kuvaa liikuntaan liittyvä toiminta.

Liikuntakokemukseen vaikuttavat erilaiset tekijät voidaan jakaa yksilöön itseensä liittyviin ja yksilön ulkopuolisiin tekijöihin. Mallin (Fox 1998) kysymys "Kuka minä olen?" viittaa yksilöön itseensä. Ihminen on psykologinen kokonaisuus, joka sisältää fyysisen, psyykkisen ja sosiaalisen minän. Fyysistä minää voidaan tarkastella suppeasti fyysisen kunnon ja voiman kautta, jolloin geeniperimän merkitys kehon kokoon, muotoon ja fysiologiaan on oleellinen. Myös sekä yksilön kypsyys että harjoittelun teho ja määrä vaikuttavat kuntoon ja voimaan. (Fox 1998.) Fyysinen minä on kuitenkin edellä kuvattua laajempi kokonaisuus.

Myönteinen fyysinen minäkäsitys koostuu viehättävästä vartalosta, koetusta liikunnalli- sesta pätevyydestä, fyysisestä voimasta ja fyysisestä kunnosta (Fox \& Corbin 1989). March ja Redmayne (1994) laajentavat edellistä määrittäen ylemmälle tasolle ulkonäön ja fyysisen pätevyyden ja alemmalle tasolle voiman ja kestävyyden lisäksi vielä liikkuvuuden ja tasapainon. Se, miten tärkeinä yksilö pitää edellä mainittuja seikkoja, muovaa hänen fyysistä itsearvostustaan ja samalla yleistä itsetuntoaan. Psyykkisen minän osana merkityksellisiä ovat itsetunto ja itsearvostus (Stiller \& Alfermann 2007). Fox $(1997,2000)$ viittaa itsetunnosta puhuessaan Campbellin $(1984,9)$ määritelmään, jonka mukaan itsetunto on tunnepitoinen tietoisuus hyvästä minästä ("the awareness of good possessed by self"). Yksilö määrittää itsensä hyväksi suhteessa niihin kriteereihin, joilla hän itse määrittää hyvän. Tämä globaali määritelmä edustaa holistista ja fenomenologista käsitystä minästä (Fox 1997). Fyysinen ja psyykkinen minä kehittyvät iän ja kypsymisen myötä vuorovaikutuksessa ympäristön kanssa. Yhdessä nämä itseen liittyvät tekijät heijastuvat asennoitumisessa liikuntaan ja ovat pohjana tulevissa liikuntakokemuksissa (Fox 1998; Yli-Piipari 2011). 
Yksilön ulkopuoliset tekijät kohdistuvat Foxin (1998) mallin kysymykseen "Mitä liikunnassa tapahtuu?" Näitä tekijöitä ovat yksilöön vaikuttavat ihmiset (opettajat, vanhemmat, valmentajat ja luokkakaverit) sekä olosuhteet (tilat ja välineet). Koululiikunnassa opettajalla (Siedentop \& Tannehill 2000) ja opettajan tavalla opettaa (Klemola 2009) on keskeinen rooli oppilaan kokemusmaailman synnyssä. Opettaja ja muut yksilön ulkopuolella olevat tekijät määrittelevät osaltaan oppilaan kokemusta liikunnasta (Fox 1998; Palomäki \& Heikinaro-Johansson 2011).

Mainitut tekijät vaikuttavat siihen, millaisia tunnetiloja liikunta yksilössä synnyttää: "Mitä ajattelen liikunnasta ja miltä se minusta tuntuu?" Tunteet vaikuttavat voimakkaasti siihen, millaisia liikuntakokemuksia oppilaille eri liikuntatilanteissa muodostuu. Yksilöllä on pyrkimys sellaiseen käyttäytymiseen, joka tuottaa hänelle hyvän olon. Liikuntakokemuksia muokkaavat siten nautinnon tunteet, palkkiojärjestelmät, pätevyyden kokeminen, luottamus ja muut tunnetilat (Fox 1998; Yli-Piipari 2011). Fyysisen aktiivisuuden yhteydessä myönteiset tunteet viittaavat valppauteen ja toimintaan, kielteiset vihaan ja pelkoon (Biddle 2000). Fyysiset minäkokemukset voivat myönteisinä edistää itsearvostusta, koska koettu liikunnallinen kyvykkyys on ensimmäisiä osa-alueita, joilla lapsi oppii arvioimaan pätevyyttään (Fox 1998).

Oppilaan kokemusmaailma määrittää hänen tulevaa käyttäytymistään. Foxin (1998) mallissa "Mitä liikunnassa teen?" viittaa päätöksiin, omistautumiseen ja liikuntamotivaatioon. Nämä päätökset muovautuvat henkilökohtaisesti koettujen, todellisten kokemusten pohjalta. Liikunnan jatkuvan harrastamisen kannalta ratkaiseva tekijä on yksilön kokemus itsestä liikunnallisesti pätevänä (Fox 1998; Wallhead \& Buckworth 2004). Pedagogisina ja didaktisina ratkaisuina edellä esitetty Foxin (1998) malli ohjaa opettajia eläytymään lapsen maailmaan, tukemaan lapsen identiteetin muodostumista ja vahvistamaan liikunnallisen elämäntavan omaksumista. Tämä on mahdollista valitsemalla sellaisia opetusmenetelmiä, jotka seuraavat oppilaiden ajatuskulkua ja kehitysvaihetta.

\section{Tutkimusmenetelmät}

Aineiston keruu ja analyysi

Aineisto tähän tutkimukseen kerättiin viikolla 15 vuonna 2007 Google ${ }^{\mathrm{TM}}$-hakukoneen avulla hakusanalla "koululiikunta". Kyseinen viikko valittiin satunnaisesti. Sitä ennen ei ollut tapahtunut mitään yleisesti merkittävää, minkä voisi arvella kiihdyttäneen kirjoittelua koululiikunnasta. Haun ensimmäiset 200 osumaa sisälsivät yhdeksän keskustelupalstaa. Keskustelupalstat edustivat erilaisia foorumeja (www.oikeuttaelaimille.net, www.nappulafutis.com, www.myartic.net, http://ranneliike.net, www.terhi.net, http://chat.yle.fi (kaksi eri palstaa), http://demi.fi ja http://keskustelu.suomi.24.fi), joissa juuri kyseisellä viikolla keskusteltiin koululiikunnasta. Tässä tutkimuksessa aineisto kerättiin kaikille avoimilta keskustelupalstoilta. Tutkijat eivät vaikuttaneet palstoilla käytävään keskusteluun, vaan keskustelua käytiin tästä tutkimuksesta riippumatta. Keskustelupalstoilla toimivat niille tyypilliset periaatteet, joiden mukaan aikaisemmat mielipiteet saattavat herättää reaktioita, joihin seuraavat kirjoittajat reagoivat (Arpo 2005).

Kaikki edellä mainitut yhdeksän keskustelupalstaa analysoitiin tarkasti. Keskustelupalstat sisälsivät eri määrän viestejä (11-150). Jokainen viesti otettiin alkuperäisessä muodossaan mukaan tutkimukseen. Viestejä eri foorumeilta kertyi yhteensä 356. Keskustelufoorumeilla esiintyvät kirjoittajat kirjoittivat nimimerkeillä, joten heidän taustansa (esimerkiksi ikä ja sukupuoli) jäivät tuntemattomiksi. Analysoituihin keskusteluihin osallistui yhteensä 239 eri nimimerkkiä. Kirjoittajien kokemukset koululiikunnasta saattoivat vaihdella esimerkiksi sen mukaan, milloin kirjoittaja oli käynyt koulunsa. Osasta kirjoituksia voi olettaa, että koulunkäynnistä oli jo aikaa, osasta ilme- 
ni, että kirjoittaja osallistuu koululiikuntaan edelleen. Kirjoittajiin liittyvät taustatiedot eivät olleet tämän tutkimuksen mielenkiinnon kohteena. Tutkimus keskittyy viestien sisältöihin, ei viestien kirjoittajiin.

Laadullisen aineiston sisällönanalyysiin perustuen (Patton 2002) viestit kumuloituivat kolmeen ryhmään: myönteisiin, sekä myönteisiin että kielteisiin (myöhemmin lyhennetty sekä-että) ja kielteisiin viesteihin. Mikäli viesti ei sisältänyt yhtään kielteistä kommenttia, se luokiteltiin myönteisiin, ja päinvastoin. Viesti luokiteltiin sekä-että-viesteihin, jos viestissä oli yksikin kielteinen ajatus, vaikka muu olisi ollut myönteistä, ja päinvastoin. Epäselvissä tapauksissa koko tutkimusryhmä pohti asiaa yhdessä ja päätyi lopputulokseen. Tällaisia tilanteita ei juuri syntynyt. Viestit käsiteltiin peräkkäisluokittelulla kuuden kuukauden välein ja näitä luokitteluja verrattiin keskenään. Vertailu tuotti täysin saman tuloksen (100 \%). Sen jälkeen viestit jaettiin pienempiin kokonaisuuksiin eli mielipiteisiin, joita voivat olla viestin osa, lause tai yksi sana. Mielipiteitä kertyi yhteensä 652 .

Koululiikunnasta vieraantumisen tutkimuksessa käytetty malli (Carlson 1995, 473) luettelee vieraantumisen taustalla olevia ulkoisia ja sisäisiä tekijöitä. Näiden tekijöiden voidaan olettaa vaikuttavan myös oppilaan tunteisiin koululiikuntaa kohtaan. Ulkoisia tekijöitä mallin mukaan ovat opettajan persoonallisuus ja käyttäytyminen, opetussuunnitelma, luokan ilmapiiri sekä koulun ulkopuoliset tekijät. Sisäisiä tekijöitä ovat kokemus liikunnallisesta pätevyydestä, itsetunto sekä oppilaan uskomukset ja odotukset liikunnasta (Carlson 1995). Carlsonin mallin mukainen jaottelu soveltuu tämän tutkimuksen aineistoon, sillä mallilla on yhtymäkohtia aikaisemmin esiteltyyn liikuntakokemusmalliin (Fox 1998). Carlsonin mallia (1995) mukaillen mielipiteet ryhmiteltiin kirjoittajaan itseensä liittyvien ja kirjoittajan ulkopuolisten tekijöiden mukaan. Internetin keskustelupalstoilla olevissa, koululiikuntaan liittyvissä mielipiteissä olevia ulkopuolisia tekijöitä tarkastellaan toisessa ar- tikkelissa (tulossa). Tämä tutkimus kohdistui niihin mielipiteisiin, joiden taustalla olivat kirjoittajaan itseensä liittyvät tekijät. Neljä aluetta muodostui toisaalta Carlsonin mallin, toisaalta aineiston pohjalta:

1. kirjoittajan käsitys omista kyvyistään: olen hyvä / en ole hyvä liikunnassa, osaan / en osaa liikuntatunneilla, pelkään liikuntatunneilla

2. kirjoittajan tunteiden kirjo: pidän / en pidä koululiikunnasta, häpeäntunteet ja suihkutilanteet

3. kirjoittajan uskomukset koululiikunnasta: millaista koululiikunnan pitäisi / ei pitäisi olla, koululiikuntaa koskevia ohjeita muille

4. välttelyt ja selittelyt: poissaolojen selittelyt, kavereiden kokemukset ja koulun ulkopuoliset, liikuntaan liittyvät tekijät.

Joissakin yksittäisissä tapauksissa jaottelu kirjoittajaan itseensä ja hänen ulkopuolisiin tekijöihin oli ongelmallista. Näissä tapauksissa paino pantiin nimenomaan siihen, kuinka viestistä oli luettavissa tärkein sanoma. Esimerkiksi suihkutilanteet voitaisiin luokitella olosuhteisiin, mutta tässä yhteydessä oleellisemmaksi todettiin häpeäntunne, joten tällainen viesti sijoitettiin tunteiden kirjoon, kirjoittajaan itseensä liittyviin tekijöihin. Liikunnan arvosana sisällytettiin oman pätevyyden kokemisen yhteyteen, vaikkakin se olisi luokiteltavissa myös ulkoiseksi tekijäksi.

\section{Internet aineiston keruun välineenä}

Internet voidaan nähdä kulttuurin muotona, jossa ihmiset rakentavat virtuaalipersoonia ja sosiaalisia hahmoja itselleen ja muille (Basset \& O'Riordan 2002). Internet on myös sosiaalinen ympäristö, jossa voi julkaista omia ajatuksiaan ja tunteitaan (Bruckman 2002). Tässä tutkimuksessa oletamme, kuten Pitts (2004), että keskustelufoorumit ovat rehellisiä ja aiheet, jotka kirjoittajat sinne nostavat, ovat heille todellisia (Paasonen 2006). Toisaalta kirjoittajan oma tai mahdollisesti keksitty rooli voi muodostua todentuntuiseksi, kun se vah- 
vistuu viestien vaihdosta syntyneessä dialogissa (Niemi-Pynttäri 2007). Edellisen viestin provosoimana voi oma viesti saada liioiteltuja tai vastaavasti väheksyttyjä korostuksia. Tässä tutkimuksessa viestejä kirjoitti yhteensä 239 nimimerkkiä yhdeksälle eri keskustelupalstalle, joten varsinaista nimimerkkien välistä ketjuuntumista ei muodostunut.

Nettitutkimuksen etiikka on riippuvainen tutkimuksen luonteesta ja tutkittavasta aiheesta (Arpo 2005; Basset \& O'Riordan 2002). Tutkimuksen aihealueen luottamuksellisuus ja yksityisyys vaikuttavat eettisiin ratkaisuihin (King 1996; Laukkanen 2007). Tässä tutkimuksessa aineisto kerättiin kaikille avoimilta keskustelupalstoilta. Aihealueena koululiikunta on julkinen, joten erityistä lupaa aiheen tutkimiseen ei haettu. Internetin kautta kerättävän aineiston eettisiin ydinkysymyksiin kuuluu kirjoittajien yksityisyyden suoja ja tutkittavien informointi (Arpo 2005). Yksityisyyden suojaamiseksi kaikki aineistossa käytetyt nimimerkit on korvattu koodeilla, eikä niiden perusteella kirjoittajaa voi tunnistaa. Tutkimuksesta ilmoittaminen keskustelupalstojen kirjoittajille olisi ollut täysi mahdottomuus, kos- ka kirjoittajia / nimimerkkejä oli niin paljon ja kirjoitukset jakaantuivat yhdeksälle eri keskustelupalstalle. Viestit kerättiin viikon 15 aikana, jolloin kyseisellä palstalla saattoi esiintyä jo jonkin aikaa sitten kirjoitettuja viestejä, joten kirjoittajien tavoittaminen tässäkin suhteessa olisi ollut mahdotonta. Tämä tutkimus ei etsi vastausta kysymyksiin, kuka oli kirjoittanut viestit, millainen kirjoittajan tausta (ikä, sukupuoli, rotu ym.) oli, eikä siihen, milloin kirjoittaja oli käynyt koulunsa.

\section{Tulokset}

Analyysin perusteella kaikista mielipiteistä ( $\mathrm{n}=652)$ myönteisiä oli $11 \%$, sekä myönteisiä että kielteisiä $34 \%$ ja pelkästään kielteisiä $55 \%$. Ne jakautuivat ulkoisiin $(62 \%, \mathrm{n}=$ $405)$ ja kirjoittajaan itseensä liittyviin (38\%, $\mathrm{n}=247)$ tekijöihin. Kirjoittajaan itseensä liittyvät tekijät jakautuivat myönteisiin (15\%, n $=38)$, sekä-että (39\%, n = 95) ja kielteisiin $(46 \%, \mathrm{n}=114)$ mielipiteisiin (ks. taulukko 1). Itseen liittyvistä tekijöistä selvästi eniten painottuivat tunteita kuvanneet mielipiteet (47\%). Lähes joka neljäs (24\%) mielipide

TAULUKKO 1. Myönteisten, sekä myönteisten että kielteisten ja kielteisten mielipiteiden prosenttijakauma suhteessa eri sisäisiin tekijöihin

\begin{tabular}{|l|l|l|l|l|}
\hline Sisäiset tekijät & $\begin{array}{l}\text { myönteiset } \\
\%\end{array}$ & $\begin{array}{l}\text { sekä-että } \\
\%\end{array}$ & $\begin{array}{l}\text { kielteiset } \\
\%\end{array}$ & $\begin{array}{l}\text { kaikki } \\
\%\end{array}$ \\
\hline $\begin{array}{l}\text { tunteiden kirjo } \\
n=116\end{array}$ & 8 & 21 & 18 & 47 \\
\hline $\begin{array}{l}\text { käsitys fyysisistä kyvyistä } \\
n=61\end{array}$ & 1 & 8 & 15 & 24 \\
\hline $\begin{array}{l}\text { uskomukset koululiikunnasta } \\
n=34\end{array}$ & 5 & 4 & 5 & 14 \\
\hline $\begin{array}{l}\text { välttelyt ja selittelyt } \\
n=36\end{array}$ & 1 & 6 & 8 & 15 \\
\hline $\begin{array}{l}\text { yhteensä } \\
n=247\end{array}$ & $\begin{array}{l}15 \\
n=38\end{array}$ & $\begin{array}{l}39 \\
n=95\end{array}$ & $\begin{array}{l}46 \\
n=114\end{array}$ & 100 \\
\hline
\end{tabular}


sisälsi kirjoittajan käsityksiä omista liikuntakyvyistään. Uskomukset koululiikunnasta ja tilanteiden välttelyt esiintyivät mielipiteissä lähes saman verran.

Seuraavaksi tarkastelemme lähemmin, millaisia mielipiteitä keskustelupalstoilla esiintyi. Aineiston muodostavat keskustelupalstojen viestien sisältämät mielipiteet, joita kirjoittajat keskustelupalstoilla esittivät. Sanalla "kirjoittajat" viittaamme niihin kirjoittajiin, joiden kirjoittamista viesteistä tämän tutkimuksen aineisto koostuu. Kaikki kirjoittajien käyttämät nimimerkit on muutettu koodeiksi, joissa ensimmäinen luku viittaa keskustelupalstaan ja toinen kyseisellä palstalla esitettyjen mielipiteiden esittämisjärjestystä kuvaavaan juoksevaan numeroon.

\section{Tunteiden kirjo ja kiusalliset tilanteet}

Myönteisissä mielipiteissä koululiikunta kuvattiin mukavaksi ja nautittavaksi, koska sen ei koettu olevan "pakkopullaa", vaan se koettiin rentona ja mielekkäänä. Viesteissä kerrottiin kirjoittajien pitävän tunneista, koska he kokivat osaavansa ja olevansa hyviä. He kertoivat harrastavansa liikuntaa koulun ulkopuolellakin, mikä vaikutti edelleen innostumiseen ja koululiikunnasta pitämiseen. Myös edustaminen koulujen kisoissa oli koettu mukavaksi.

Sekä-että-mielipiteet osoittivat, että varsinkin ylipainoisiksi itsensä kuvanneet kirjoittajat olivat kokeneet "kauhistukseksi" liikunnan, jossa tunsivat itsensä huonoksi, ja siksi se herätti inhon tunteita. Toisaalta yksilölajeista taas pidettiin, koska silloin tekeminen perustui omaehtoisempaan työskentelyyn. Myös muut oppilaat vaikuttivat näihin mielipiteisiin. "Trauma" ja "traumatisoitunut" olivat sanoja, joita kirjoittajat liittivät koululiikuntaan. Telinevoimistelu mainittiin useimmin ikävänä. Siinä kokemukset ylipainosta, omat heikot lihakset, itsensä satuttaminen, "pään jääminen puolapuiden väliin" ja "renkaista tippuminen" kuvattiin lamaannuttavina kokemuksina.

"Peruskoulussa liikunta oli kyllä kauhistus. Olin se ylipainoinen tyttö, joka ei osannut. Siis mui- den mielestä. Ala-asteella uskoin muita ja olin siksi huonoin ja suorastaan inhosin liikuntaa. Kun pääsin yläasteelle ja sain ihania ystäviä, liikunta ei niin enää pelottanut: olihan minulla ystäväni tukenani." $(5,44)$.

"Mutta jos oli paljon huonoa niin oli jotain hyvääkin nimittäin suunnistus. Se oli minusta aivan mahtavaa hommaa, paitsi jos satoi vettä, kuten syksyllä usein tekee. Ja suunnistaahan ei voinut kuin syksyllä. Ei minulle ole oikeastaan mitään vakavia traumoja koululiikunnasta kuitenkaan jäänyt, mutta ei vastaavasti mitään suuria onnistumisen tunteitakaan." $(7,21)$

Kielteisissä mielipiteissä kirjoittajat kuvasivat koululiikuntaa halveksittavaksi ja sanoivat, että "se oli vähä-älyistä" ja "tyhmille tarkoitettua". Aineistossa koululiikuntaa kuvattiin karmeaksi, hirveäksi, inhottavaksi, kiduttavaksi ja painajaismaiseksi. Mielipiteistä oli luettavissa, että lajeista hiihto ei ollut pidettyjen lajien joukossa, myöskään joukkuepelit eivät kiinnostaneet.

"...hävetti aina kun ei osannut, todellisuudessa en edes halunnut osata. Ei vaan kiinnosta pelata jotain vitun potkupalloa, korista ja sählyä..." $(4,23)$

"Olin sekä open että muiden silmätikku...koordinaationi on ihan surkea (en ole oppinut tanssimaan mitään tai opi yksinkertaisimpiakaan askelsarjoja) enkä tykkää ryhmätyöskentelystä yleensäkään. Joukkuepelitunneilla mulle huusi sekä ope että muut oppilaat, eli vihasin tunteja itse ja samoin niillä tunneilla vihattiin minua. Onneksi se on ohi!!!" $(4,27)$

Aineistossa kirjoittajien kertoma häpeäntunne suhteessa omaan kehoon, sen kehittymiseen ja kavereiden kehon vertailuun liittyen herätti voimakasta keskustelua. Varsinkin tuntien jälkeiset suihkutilanteet oli koettu hankaliksi. Suihkussa käyntiä suositeltiin, ettei "haise hielle" koko loppupäivää, vaikkakin "suihkupakko on pedofiilismia sanon ma" $(3,15)$. Yksi keino kaverin katseiden välttämiseen oli mennä viimeisenä suihkuun. Kirjoittajat ehdottivat liikuntatuntien sijoittamista koulupäivän loppuun, jotta julkiselta suihkussa käymiseltä vältyttäisiin. Suihkutilanteissa ongelmaksi koettiin muun muassa oman kehon kehittyminen: "Minulle tuli alakarvat muita jätkiä en- 
nen. Suihkuun meno oli kauheaa. Kauheaa" $(4,33)$.

Suihkussa käynnin lisäksi pukeutumistilanteet koettiin hankaliksi. Toiset oppilaat haukkuivat alusvaatteita ja nimittelivät ulkonäköön liittyen. Nimittely oli saanut aikaan itseinhoa, minkä jälkeen "en halunnut mennä sinne senkään takia, että meikit lähtisivät pois, jolloin he olisivat nähneet kraateria muistuttavan ihoni" (5.3). Uintitunnit kuuluivat samoihin häpeäntunteiden aiheuttajiin. Edellisten syiden lisäksi uinnissa inhotti se, että "en tykkää esitellä reisiäni julkisesti" $(8,33)$.

\section{Käsitys fyysisestä kyvykkyydestä}

Mielipiteissä kirjoittajan käsitys omasta fyysisestä kyvykkyydestä vaikutti selvästi siihen, kuinka hän kertoi osaavansa tai vastaavasti olevansa heikko koululiikunnassa. Aineistossa omaa taitoa verrattiin koulukaverin, sisarusten tai jopa omien vanhempien liikuntataitoihin. Fyysisiä kykyjään kirjoittajat kuvasivat ilmaisuilla kömpelö, paksu, surkea, huono, ei hienoja motorisia taitoja, en lainkaan liikunnallinen, en todellakaan mikään hyvä, ujo, epävarma, laiska, olisin halunnut olla yhtä etevä kuin ja kaikki muut loistavat kustannuksellani. Käsitys omista kyvyistä muotoutui suhteessa toisiin: "Ja se pännii kun muut osaa ja minä en. Argh" $(8,82)$.

Liikuntalajit, joissa kirjoittajat kokivat olevansa hyviä, vaihtelivat suuresti (ks. myös Palomäki \& Heikinaro-Johansson 2011). Aineistossa esiintynyt kirjoittajan oma käsitys siitä, että olen / en ole hyvä koululiikunnassa, jakautui eri lajien kesken siten, että kirjoittajat kokivat itsensä hyväksi selvimmin uinnissa ja telinevoimistelussa. Lisäksi kuulantyöntö, hiihto, luistelu, tanssi ja palloilu mainittiin. Lajit, joissa kirjoittajat kokivat itsensä huonoiksi, olivat osittain samoja kuin edellä mainitut, eli eri palloilulajit, telinevoimistelu, yleisurheilu, hiihto, luistelu ja tanssi. Mielipiteissä tuli selvästi ilmi se, että kirjoittajat kokivat, etteivät he osanneet eri liikuntalajeja.

"... Totaalisen tumpelona ja täysin ilman min-

käänlaista käden ja silmän koordinaatiota liikun- nan saldo oli negatiivinen. Pesäpallossakin pallo osui minuun useammin kuin minä mailalla palloon" $(4,31)$.

Eri lajeihin (uinti, telinevoimistelu, suunnistus ja hiihto) ja niissä oleviin tiettyihin suorituksiin (kasvojen painaminen veden alle, uimahypyt, sukellukset, kuperkeikka, pukkihypyt, neulansilmäkiepit rekillä, kompassin kanssa tuntemattomassa maastossa ja jyrkkien mäkien lasku) liittyi jopa pelkoa.

"Näin aina painajaisia etukäteen. Vihasin ja pelkäsin telinevoikkaa melkein enemmän kuin hammaslääkäriä. Kaikki liikkeet oli pakko tehdä, eikä niistä mitään tullu, kun tuska ja vapina teki kropan viulunkielen kireeks..." $(7,38)$

"Kamalaa! Pelkään niitä pukkeja yms. en uskalla tehdä mitään. Liikunta oikeastaan mittaa rohkeutta" $(8,15)$.

Kirjoittajaan itseensä liittyviin tekijöihin liitimme myös kommentit liikuntanumerosta koska ne liittyivät läheisesti käsitykseen itsestä. Aineistossa mainitut kirjoittajien liikuntanumerot vaihtelivat. Kaikissa mielipiteissä niistä ei mainittu, vain noin yksi kolmasosa (19/61) mielipiteistä liittyi liikuntanumeroon. Positiivisia mielipiteitä kirjoittaneilla liikuntanumero oli 9-10 (3/3). Sekä-että-kirjoituksissa numerot olivat 6-9 (6/20): "Liikuntanumeroni oli aina seiska, tein sitten mitä hyvänsä - epäilen, että numeron sai ruumiinrakenteen perusteella." $(5,29)$ Kielteisten mielipiteiden kirjoittajien numeroskaala oli 6-8 (10/38)

\section{Uskomukset ja odotukset koululiikunnasta}

Positiiviset mielipiteet koululiikunnasta olivat monipuolisia. Jotkut keskustelupalstoille kirjoittaneet olivat saaneet koululiikunnasta kipinän jatkuvaan liikunnan harrastukseen. Kirjoituksissa toivottiin pakollista liikuntaa, koska muuten liikunnan määrä voisi jäädä vähäiseksi. Kirjoittajat kommentoivat myös muiden asennetta koululiikuntaa kohtaan. Asenteeseen voi kirjoittajien mielestä itse vaikuttaa, eikä siihen tarvita opettajan apua. Mielipiteissä neuvottiin, että "liikunnastakin 
tulisi kivempaa ja helpompaa jos yrittäisitte $^{\prime \prime}(8,85)$. Liikuntanumeroita kirjoituksissa puollettiin sillä, että muuten yrittäminen voi jäädä, jos liikuntaa ei arvostella kuten muitakin aineita. Tosin numeron antamisen perusteista todettiin, että numero annettaisiin pikemminkin sen mukaan, kuinka innostunut on ollut tunnilla. Liikuntaa verrattiin muihin aineisiin:

"Joku saksan tai matikantunti on ihan eri asia.. Jos et haluu olla ahkera ni ei tarvii. Voi valita itse haluaako olla tunneilla passiivinen vai osallistua tapahtumii aktiivisemmin. Liikkatunnilla on pakko tehä ne kaikki jutut muiden kattoessa vierestä. On oikeesti ikävää, jos itsetunto laskee siitä. Urheilunhan pitäis kasvattaa itsetuntoo." $(8,135$.)

Haasteena koululiikunnalle kirjoittajat esittivät, että sen tulisi olla "mukavaa, mielekästä ja motivoivaa". Kaikenlainen "nöyryyttäminen, ilkeä vertailu toisiin ja pakottaminen saisi kuulua historiaan" $(7,38)$. Lajien valinnanvapautta toivottiin, mutta myös opetuksen laatuun kiinnitettiin huomiota. Opettajakoulutus sai joissakin mielipiteissä kritiikkiä. Siihen puututtiin toteamalla, että

"Liikunnanopettajaksi ei yleisesti ottaen pääse, jos ei ole juuri tuollainen joukkuepeliluonne, joten ymmärrystä et tule saamaan - opettajallasi ei välttämättä ole yhtään tajua siitä, millainen tilanne sinun kannaltasi on. Opekoulutus pitää sisällään kaikenlaista psykologian pätkää, mutta se on hyödytöntä, jos sen oppii ulkoa muttei sisäistä" $(9,8)$

Välttelyä ja selittelyä

Itseensä liittyviin tekijöihin sisällytimme välttelyt ja selittelyt, joita olivat lähinnä tunneilta poissaoloihin liittyvät kirjoitukset. Erilaisia tapoja selitellä poissaoloja oli useita. Kirjoittajat kertoivat avoimesti, että he pinnaavat järjestelmällisesti ja valehtelevat aikomuksestaan hankkia luistimia tai suksia, kun koulun välineet olivat väärää kokoa, ja jopa elämänkatsomuksellisia näkemyksiä käytettiin perusteluna: "Yläasteella sanoin et mun uskonto kieltää luistelun ja jouduin harjoittelemaan yksin sivussa, ihan hyvä" $(5,22)$. Kirjoittajien mukaan suunnistustunneilla he etsivät ensim- mäisen rastin ja sen jälkeen menivät tupakalle. Opettajalle he selittivät, että rasteja ei löytynyt. Samoin pitkä juoksulenkki oli saatettu tehdä linja-autolla, tai välillä oli käyty kotona syömässä. Koululla opettajan edessä oli näytelty hengästynyttä.

Tässä tutkimuksessa kokosimme muihin sisäisiin tekijöihin myös kirjoittajien kertomia, kaverille sattuneita tilanteita. Kirjoittajan kaveri "lintsasi uinnista ja sanoi, että on muka peräpukamia. Ei silloin edes tiedetty mitä ne on" $(7,75)$. Kaveriin kohdistuneesta vääryydestä oli useita mielipiteitä. Ulkonäköön liittyvät paineet aiheuttivat sen, että "luokkatoverini varaavat vessa vuoroja, kun he eivät viitsi vaihtaa liikunta vaatteita pukuhuoneessa" $(3,10)$.

"... Koulussani oli yksi tyttö vähän huonommasta perheestä, eikä hänellä ollut liikuntavaatteita. En usko että vanhempia kiinnosti hankkia. Tyttö oli isokokoinen ja murrosikä oli alkanut jo pahasti ala-asteella. Koska tyttö oli tullut liikuntatunnille farkuissa, niin opettaja pakotti tytön olemaan alusvaatteissa siellä tunnilla. Tyttö meni istumaan ikkunalaudalle verhon taakse ja itkemään, jonne opettaja sitten unohti hänet..." $(5,46)$

Koulun ulkopuolinen tai varsinaisen kouluajan jälkeinen liikunta oli motivoinut useita kirjoittajia. Kun '"pakko" ja "kilpailullisuus" olivat ohi, niin liikunnasta oli voinut nauttia ja harrastaa sitä vapaa-aikana. "Kun sitten itse innostuin aerobickistä myöhemmin, oli valtava oivallus että liikkumisesta voi nauttia ilman suorituspaineita" $(5,38)$.

\section{Yhteenveto ja pohdinta}

Tämän tutkimuksen tarkoitus oli selvittää, millaisena koululiikunta näyttäytyy internetin keskustelupalstoilla. Erityisesti mielipiteissä ilmaistut kirjoittajaan itseensä liittyvät tekijät olivat tutkimuksen kohteena. Niihin paneutumalla tarkastelimme, millaisia ajatuksia ja tunteita koululiikunta herättää. Aineistosta erottui neljä osa-aluetta, joista selvästi suurimmaksi muodostui erilaiset kirjoittajaan itseensä liittyviä tunteita käsittelevät mielipiteet. Niissä mielipiteissä yleisin oli jokin kielteiseksi koet- 
tu tunne, joka liittyi liikuntatilanteeseen tai -lajiin, jota kirjoittajat kuvasivat ärsyttäväksi, inhottavaksi, hävettäväksi tai pelottavaksi. Pelkoa ilmeni varsinkin silloin, kun käsitys omasta liikunnallisuudesta oli heikko. Haasteena koululiikunnalle kirjoittajat esittivätkin, että sen tulisi olla mielekästä ja motivoivaa, ei kilpailullista, nöyryyttävää ja pakottavaa.

Useiden aikaisempien tutkimusten mukaan koululiikunta koetaan pääosin myönteisesti (mm. Dyson 2006; Palomäki \& Heikinaro-Johansson 2011; Subramaniam \& Silverman 2007). Tässä tutkimuksessa havaittiin, että internetin keskustelupalstojen viesteissä ja mielipiteissä esiintyy paljon (55 \% / $46 \%$ ) kielteisiä ilmauksia. Tulos oli vastoin odotuksia ja aiempien tutkimusten antamaa myönteistä kuvaa liikunnasta. Oletamme, että tulosta selittää toisaalta tutkimusmetodi, jossa kirjoittajat saattoivat ilmaista mielipiteitään tunnistamattomina, toisaalta käyttämämme aineiston analysoinnin tapa. Sisällönanalyysissa otimme huomioon jokaisen yksittäisenkin myönteisen tai kielteisen mielipiteen. Tämänsuuntaista tarkkaa sisällöllistä luokittelua ja rajausta ei ole käytetty aikaisemmissa tutkimuksissa.

Tämän tutkimuksen kohteena olleissa viesteissä vastenmielisyys koululiikuntaan näyttää syntyvän voimakkaista kielteisiä tunteita herättävistä kokemuksista. Aikaisemmat tutkimukset (Kokkonen 2010; Laukkanen 2007; Pennebaker 1997) ovat osoittaneet, että ihmisille on fyysisesti ja henkisesti hyödyllistä kirjoittaa emotionaalisista kokemuksistaan. Tuloksista voi päätellä, että anonyymisti kirjoitettavat viestit internetin keskustelupalstoilla antavat mahdollisuuden purkaa poikkeuksellisen voimakkaastikin tunteita. Keskustelupalstoja analysoimalla voidaan siis kuulla kirjoittajan ääntä. Internetin keskustelupalstojen aineistosta tehtävän tutkimuksen hyötynä voidaan pitää sitä, että sosiaalinen paine ja tarve "miellyttää" haastattelijaa tai esimerkiksi opettajaa puuttuu (Seale ym. 2010). Tätä tunteiden syvyyden tasoa ei voi samalla tavoin tavoittaa aikaisemmin käytetyillä tutkimusmenetelmil- lä. Etenkin niissä tapauksissa, joissa vastataan kysymyksiin koulussa, voidaan kokea pelkoa paljastumisesta.

Kuvaukset omasta kehosta ja siihen liittyvistä häpeän tunteista kuvaavat sitä epävarmuutta, jota kirjoittaja kokee. Epävarmuuden taustalla lienee yhdenmukaisuuden paine (Kenway \& Bullen 2001). Minän hyväksyminen sellaisena kuin se on, heijastaa arvomaailmaa. Tämän päivän nuoren maailmassa ulkoisilla ominaisuuksilla on entistä merkittävämpi asema, eikä virtuaalinen nettimaailma ainakaan vähennä sen merkitystä (Kenway \& Bullen 2001; Rich \& Miah 2009). Näillä kirjoittajaan itseensä liittyvillä tekijöillä näyttäisi olevan suuri merkitys siinä, mitä liikunnasta ajatellaan ja miltä liikunta yksilöstä tuntuu. $\mathrm{Ne}$ vaikuttavat myös siihen, kuinka koulun liikuntakasvatus onnistuu tavoitteessaan.

Keskustelu nettipalstoilla osuu hyvin Foxin liikuntakokemusmallin (kuvio 1) kysymykseen "Kuka minä olen?" Mallin mukaan (Fox 1998) yksilön kokema todellisuus muovautuu mainittujen yksilöön itseensä liittyvien tekijöiden lisäksi palkkioista, kuten arvosanoista, voittajajoukkueessa pelaamisesta, edustustehtävistä ja muiden ihailusta. Liikkumisen ilo ja koettu pätevyys vaikuttavat myös osaltaan siihen, miltä liikkuminen yksilöstä tuntuu (YliPiipari 2011). Ilahduttavaa oli, että liikunnan arvosana ei näyttänyt suoraviivaisesti liittyvän kokemuksiin. Hyvän arvosanan (8) saaneet kirjoittivat sekä myönteisistä että kielteisistä kokemuksista (vrt. Palomäki \& Heikinaro-Johansson 2011).

Kokemusten syntyminen on todennäköisesti hyvin tilanneherkkää. Opettajan tulisi pyrkiä luomaan ilmapiiri, jossa hyväksytään erilaisuus ja erilaiset arvot. Muussa tapauksessa on vaarana, että liikuntakasvatuksessa välittyy sellainen ihmiskuva, jossa ihmisarvo perustuu vain fyysisiin suorituksiin. Luottamus itseensä ja luokkakavereihin luo positiivista ilmapiiriä, jossa on tilaa erilaisille tunteille (Barkoukis 2007). Nämä seikat vaikuttavat siihen, millaisia päätöksiä yksilö tekee suhteessa liikuntaan. Selittelyt ja poissaolot ilmentävät 
suoraan kielteisten tunteiden tuottamaa välttämiskäyttäytymistä - kielteistä asennetta silloin, kun yrittäminen ei kiinnosta.

Tämän tutkimuksen rajoituksiin kuuluu se, että internetin aineistosta tehtävään tutkimukseen jää aukkoja, joita on mahdoton täyttää nimimerkkien avulla kirjoittaneiden teksteistä. Tällaisia aukkoja ovat esimerkiksi kirjoittajan sukupuoli, ikä ja muu sosiaalinen tausta. Emme myöskään pysty vastaamaan siihen, milloin ja miksi joku kirjoittaa koululiikunnasta internetin keskustelupalstalle. Tosin tässä tutkimuksessa emme tähän tarkasteluun pyrkineetkään, koska päämäärämme oli tutkia kirjoituksia, ei niiden kirjoittajia. Emme myöskään pysty vastaamaan kysymykseen, kertooko kirjoittajan tuottama viesti ja sen sisältö aidosta kokemuksesta vai onko se liioiteltua tai aliarvostavaa kertomista. Menetelmän taustalla on lähtökohta, että kirjoittajan omaa kokemusta arvostetaan ja mielipide halutaan kuulla. Emme halua kyseenalaistaa, mitätöidä tai väheksyä kokemuksen todenperäisyyttä, vaan kuulla niistä tekijöistä, joita kirjoittajat syystä tai toisesta nostavat esiin keskustelupalstoilla (Arpo 2005).

On huomattava, että tämän tutkimuksen tuloksia voidaan peilata vain tutkimusaineistona olleeseen kohdejoukkoon (Markham 1998). Tässä tutkimuksessa pääpaino oli liikuntakokemuksiin liittyvien viestien analysoinnissa, ei yksittäisten henkilöiden tasolla tapahtuvassa tulkinnassa. Kirjoittajien käyttämiä nimimerkkejä oli paljon $(\mathrm{n}=239)$ suhteessa viestien määrään $(n=356)$. On siis oletettavaa, että viestit eivät ole vain yhden tai muutaman kirjoittajan yhdeksällä palstalla julkaistuja mielipiteitä. On kuitenkin mahdollista, että keskustelupalstat innoittavat kielteisiä kokemuksia saaneita osallistumaan keskusteluun muita aktiivisemmin.

Huolimatta siitä, että tämän tutkimuksen tulokset perustuvat internetin keskustelupalstojen viesteihin, voidaan sen kautta vetää johtopäätöksiä koululiikuntaa koskien. Tulokset viittaavat siihen, että liikuntakasvatuksen tavoitteiden saavuttamiseksi emotionaalisiin ti- lanteisiin ja pedagogisiin ratkaisuihin tulisi kiinnittää entistä enemmän huomiota. Tulevaisuudessa olisi tarpeellista jatkaa tutkimusta, jotta liikuntakasvatuksen tueksi ja erilaisten oppilaiden huomioon ottamiseksi voitaisiin löytää uusia keinoja. Tulokset antavat perusteita esittää, että kirjoitusten taustalla on inhimillinen kokemus. Terveen itsetunnon muodostumisen kannalta koulukokemukset ovat merkityksellisiä. Koululiikunnasta saataviin kokemuksiin voidaan vaikuttaa ottamalla oppilas hienotunteisesti huomioon tuntien aikana. Pätevyyden kokeminen ja positiivisen palautteen saaminen ovat avainasemassa (Stiller \& Alfermann 2007). Opettajilla on tässä suuri merkitys (Graham 2008; Rink 2010). Opettajan on tunnistettava tilanteet, joissa oppilas saattaa kokea häpeää ja pelkoa. Näitä tilanteita olisi mahdollisuuksien mukaan pyrittävä pedagogisilla ja didaktisilla ratkaisuilla ehkäisemään ennalta käyttämällä sellaisia opetustyylejä, jotka synnyttävät pätevyyden kokemuksia.

Tämän tutkimuksen tuloksia voidaan hyödyntää suunniteltaessa opettajankoulutuksen tavoitteita ja sisältöjä. Opettajan sensitiivisyys oppilaan tunteille ja tunteiden ilmaisulle sekä niiden käsittely vaativat opettajalta todellisia vuorovaikutustaitoja (Klemola 2009). Opettajankoulutuksessa tulisi entistä enemmän kiinnittää huomiota oppilaiden erilaisuuden ja herkkyyden tunnistamiseen, kun kysymyksessä on oma fyysinen minä.

\section{Lähteet}

Arpo, R. 2005. Internetin keskustelukulttuurit: Tutkimus internet -keskusteluryhmien viesteissä rakentuvista puhetavoista, tulkinnoista ja tulkinnan kehyksistä kommunikaatioyhteiskunnassa. Joensuun yliopiston humanistisia julkaisuja 39.

Barkoukis, V. 2007. Experience of state anxiety in physical education. Teoksessa J. Liukkonen, Y. V. Auweele, B. Vereijken, D. Alfermann \& Y. Theodorakis (toim.) Psychology for physical educators. 2. painos. Champaign, IL: Human Kinetics, 57-72.

Bassett, E. H. \& O'Riordan, K. 2002. Ethics of Internet research: Contesting the human subjects research model. Ethics and Information Technology 4, 233-247. 
Berg, P. 2010. Ryhmärajoja ja hierarkioita: Etnografinen tutkimus peruskoulun yläasteen liikunnanopetuksesta. Helsingin yliopiston sosiaalipsykologian laitos, Sosiaalipsykologisia tutkimuksia 22

Biddle, J. H. 2000. Emotion, mood and physical activity. Teoksessa S. J. H. Biddle, K. R. Fox \& S. H. Boutcher (toim.) Physical activity and psychological well-being London: Routledge, 63-87.

Biddle, S., Wang, C., Chatzisarantis, N. \& Spray, C. 2003. Motivation for physical activity in young people: Entity and incremental beliefs about athletic ability. Jour nal of Sport Sciences 21 (12), 973-989.

Bruckman, A. 2002. Studying the amateur artist: A perspective on disguising data collected in human sub jects research on the Internet. Ethics and Information Technology 4 (3), 217-231.

Campbell, R. N. 1984. The new science: Self-esteem psychology. Lanham, MD: University Press of America.

Carlson, T. 1995. We hate gym: Student alienation from physical education. Journal of Teaching in Physical Education 14 (4), 467-477.

Carroll, B. \& Loumidis, J. 2001. Children's perceived competence and enjoyment in physical education and physical activity outside school. European Physical Education Review 7 (1), 24-43.

Cothran, D. J . \& Kulinna, P. H. 2007. Students' reports of misbehavior in physical education. Research Quarterly for Exercise and Sport 78 (3), 216-224.

Dyson, B. 2006. Students' perspectives of physical education. Teoksessa D. Kirk, D. Macdonald \& M. O'Sullivan (toim.) The handbook of physical education London: Sage, 326-346.

Fox, K. R. 1997. The physical self and processes in self esteem development. Teoksessa K. R. Fox (toim.) The physical self: from motivation to well-being. Champaign, IL: Human Kinetics, 111-139.

Fox, K. R. 1998. Lapsen näkökulmia liikunnassa - liikuntakasvatuksen psykologinen ulottuvuus. Teoksessa E. L. Sarlin, H. Sarlin, T. Lintunen, J. Liukkonen \& A. Pönk kö (toim.) Motivaatio ja minäkäsitys liikunnassa ja ur heilussa. Vuokatin liikuntapsykologinen seminaari. Oulun yliopiston Kajaanin opettajankoulutuslaitoksen julkaisuja B: 10, 1-3.

Fox, K. R. 2000. The effects of exercise on self-perception and self-esteem. Teoksessa S. J.H. Biddle, K. R. Fox \& S H. Boutcher (toim.) Physical activity and psychological well being. London: Routledge, 88-117.

Fox, K. R. \& Corbin, C. B. 1989. The physical self-perception profile: development and preliminary validation. Journal of Sport \& Exercise Psychology 11 (4), 1-12.

Graham, G. 2008. Teaching children physical education. Becoming a master teacher. Champaign, IL: Human Kinetics.

Johansson, N., Heikinaro-Johansson, P. \& Palomäki, S. 2011. Kohtaavatko peruskoulun opetussuunnitelman tavoitteet ja oppilaiden kiinnostus liikunnanopetuksessa? Teoksessa S. Laitinen \& A. Hilmola (toim) Taitoja taideaineiden oppimistulokset asiantuntijoiden ar- viointia. Helsinki: Opetushallitus, 237-248

Kangasniemi, J. 2008. Yksinäisyyden kokemisen avainkomponentit Yleisradion tekstitelevision Nuorten palstan kirjoituksissa. University of Jyväskylä, Jyväsky lä Studies of Humanities 107.

Kenway, J. \& Bullen, E. 2001. Consuming children. Education-entertainment-advertising. Maidenhead:Open University Press.

King, S. 1996. Researching Internet communities: Proposed ethical guidelines for the reporting of the results. The Information Society 12 (2), 119-127.

Kirk, D. 2005. Physical education, youth sport and lifelong participation: The importance of early learning experiences. European Physical Education Review 11 (3) 239-255.

Klemola, U. 2009. Opettajaksi opiskelevien vuorovaikutustaitojen kehittäminen liikunnan aineenopettajakoulutuksessa. Jyväskylän yliopisto. Studies in Sport, Physical Education and Health 139.

Kokkonen, M. 2010. Ihastuttavat, vihastuttavat tunteet Jyväskylä: PS-kustannus.

aukkanen, M. 2007. Sähköinen seksuaalisuus:Tutkimus tyttöydestä nettikeskusteluissa. Rovaniemi: Lapin yliopistokustannus.

March,H.W. \& Redmayne, R. S. 1994. A multi-dimensional physical self-concept and its relations to multiple components of physical fitness. Journal of Sports \& Exercise Psychology 16 (1), 43-55.

Markham, A. N. 1998. Life online. Researching real experience in virtual space. Walnut Creek, CA: AltaMira Press.

Morgan, P. \& Hansen, V. 2008. The relationship between $\mathrm{PE}$ biographies and $\mathrm{PE}$ teaching practices of classroom teachers. Sport, Education and Society 13 (4), 373-391.

National association for sport and physical education (NASPE). Moving into the future: National standards for physical education 2004. Reston: NASPE.

Niemi-Pynttäri, R. 2007. Verkkoproosa: tutkimus dialogisesta kirjoittamisesta. Helsinki: ntamo.

Nupponen, H., Penttinen, S., Pehkonen, M., Kalari, J. \& Paosaari, A.-M. 2010. Koululiikunnan vaikuttavuustutkimus: Lähtökohdat, menetelmät ja aineiston kuvaus. Turun yliopisto, opettajankoulutuslaitos, Rauman yksikkö.

Paasonen, S. 2006. Identiteetti Internetissä. Teoksessa A Mäkelä, L. Puustinen \&I. Ruoho (toim.) Sukupuolishow. Johdatus feministiseen mediatutkimukseen. Helsinki Gaudeamus, 149-167.

Palomäki, S. \& Heikinaro-Johansson, P. 2011. Liikunnan oppimistulosten seuranta-arviointi perusopetuksessa 2010. Helsinki: Opetushallitus.

Patton, M. 2002. Qualitative research \& evaluation methods. Thousand Oaks, CA: Sage.

Pennebaker, J. W. 1997. Writing about emotional experiences as a therapeutic process. Psychological Science 8 (3), 162-166

Perttula, J. 2009. Kokemus ja kokemuksen tutkimus: Fenomenologisen erityistieteen tieteenteoria. Teoksessa 
J. Perttula \& T. Latomaa (toim.) Kokemuksen tutkimus: merkitys, tulkinta, ymmärtäminen. Tampere: Juvenes Print, 115-162.

Perusopetuksen opetussuunnitelman perusteet (POPS) 2004. Helsinki: Opetushallitus.

Pitts, V. 2004. Illness and Internet empowerment: Writing and reading breast cancer in cyberspace. Health 8 (1), 33-59.

Ransom, D. C., La Guardia, J. G., Woody, E. Z \& Boyd, J. L. 2010. Interpersonal interactions on online forums addressing eating concerns. International Journal of Eating Disorders 43 (2), 161-170.

Rich, E. \& Miah, A. 2009. Prosthetic surveillance: The medical governance of healthy bodies in cyberspace. Surveillance \& Society $2,163-177$.

Rikard, G. L. \& Banville, D. 2006. High school students' attitudes about physical education. Sport, Education and Society 11 (4), 385-400.

Rink, J. 2010. Teaching physical education for learning. New York, NY: McCraw-Hill.

Seale, C., Charteris-Black, J., MacFarlane, A. \& McPherson, A. 2010. Interviews and Internet forums: a comparison of two sources of qualitative data. Qualitative Health Research 20 (5), 595-606.

Siedentop, D. \& Tannehill, D. 2000. Developing teaching skills in physical education. 4. painos. Mountain View, CA: Mayfield.
Stiller, J. \& Alfermann, D. 2007. Promotion of a healthy self-concept. Teoksessa J. Liukkonen, Y. V. Auweele, B. Vereijken, D. Alfermann \& Y. Theodorakis (toim.) Psychology for physical educators. 2. painos. Champaign, IL: Human Kinetics, 123-140.

Subramaniam, P. R. \& Silverman, S. 2007. Middle school students' attitudes towards physical education. Teaching and Teacher Education 23, 602-611.

Tapscott, D. 2009. Grown up digital: How the Net Generation is changing your world. NewYork: McGraw-Hill. Tilastokeskus 2011. Tieto- ja viestintätekniikan käyttö. http://www.stat.fi/til/sutivi/index.html. Luettu 20.4.2012.

Trudeau, F. \& Shephard, R. J. 2005. Contribution of school programmes to physical activity levels and attitudes in children and adults. Sport Medicine 35 (2), 89-105.

Trout, J. \& Graber, K. 2009. Perceptions of overweight students concerning their experiences in physical education. Journal of Teaching in Physical Education 28 (3), 272-292.

Wallhead, T. L. \& Buckworth, J. 2004. The role of physical education in the promotion of youth physical activity. Quest 56 (3), 285-301.

Yli-Piipari, S. 2011. The development of students' physical education motivation and physical activity: A 3.5-year longitudinal study across grades 6 to 9. University of Jyväskylä, Studies in Sport, Physical Education and Health 170.

Saapunut toimitukseen 20.5.2011

Hyväksytty julkaistavaksi 3.4.2012 
“PE AT OUR SCHOOL HAS BEEN RELATIVELY VARIED RECENTLY, BUT...": FACTORS OF ENGAGEMENT IN OR ALIENATION FROM SCHOOL PE

by

Lauritsalo Kirsti, Sääkslahti Arja \& Rasku-Puttonen Helena (submitted) 


\begin{abstract}
"PE at our school has been relatively varied recently, but...": Factors of engagement in or alienation from school PE

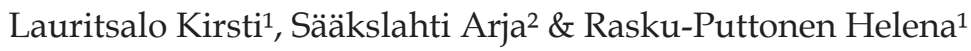

${ }^{1}$ Department of Teacher Education, University of Jyväskylä.

${ }^{2}$ Department of Sport Sciences, University of Jyväskylä.
\end{abstract}

\begin{abstract}
:
The purpose of this study was to examine how people write about school physical education in Internet discussion forums: what factors seem to lead writers to include negative thoughts in mainly positive messages, and vice versa. The data were collected from open Internet discussion forums during a randomly chosen week in April 2012. All the messages were analysed in three phases using qualitative content analysis. The curriculum clearly emerged as the main factor influencing writers' feelings and perceptions. In order of frequency, the other factors were teacher, class environment, and range of emotions. The results are discussed in relation to the importance of listening to opinions expressed in Internet discussion forums on the topic of school physical education and the implications of this for school physical education practice.
\end{abstract}

Keywords:

School Physical Education; Internet discussion forums; messages

School physical education (PE) is a subject that strongly divides people's feelings and perceptions. At its best, school physical education can lead to enjoyment in future physical activities and a lifelong engagement in a physically active lifestyle (Bevans et al., 2010; Bailey, 2006). Unfortunately this is not always the case. In the worst cases, the result is precisely the opposite, meaning withdrawal from physical activities and alienation from physical education (Carlson, 1995; Halas, 2002; Spencer-Cavaliere and Rintoul, 2012). There is a polarity (Mann, 2001) between engagement in and alienation from school PE. When school PE has succeeded in its main aim of encouraging the student's physical activity and self-esteem (NASPE, 2004), the positive feelings and experiences gained thereby can lead towards engagement in PE. Positive influences are strengthened by functional co-operation with other students and the teacher (Strean, 2009), and also with the surrounding physical culture (Enright and O'Sullivan, 2013; Flory and McCaughtry, 2011). When school PE has not achieved these targets and other unwanted events and situations have occurred, the student's feelings might take negative turn towards alienation from PE. School PE, when appropriately delivered, supports the aim of instilling the confidence needed to enjoy a lifetime of healthful physical activity (NASPE, 2004) and engagement. 
Although curricula vary across cultures, the general aims of the PE curriculum remain much the same (Annerstedt, 2008). According to the Finnish national core curriculum for basic education (2004), the aim of PE is to build the pupil's self-esteem and a positive physical self-concept through favourable PE experiences, and to encourage cooperativeness and positive future sport and health behaviour. Different sports, understood here as an umbrella term for multiple forms of physical activity, and sport disciplines within school physical education work as tools preparing students to feel confident with their selves and about their self-efficacy (Stodden et al., 2008; Welk, 1999). Unfortunately this does not always happen so optimally. For example, in their study on boys' perceptions of the intersection between masculinity and school PE, Tischler and McCaughtry (2011) recommend that teachers should take time to find out what activities their students like or dislike and, especially, why. To be able to feel competent about oneself, a student needs positive experiences. This requires first of all adequate physical skills, in basic movements, as argued by Gibbons and Humbert (2008) in their study of middle school girls, as well as in more challenging tasks (Stodden et al., 2008). In addition to physical skills, cognitive and affective abilities can promote engagement in physical activity (NASPE, 2001). Teachers' teaching skills and methods also have an important influence on the meaning of PE for students (Spencer-Cavaliere and Rintoul, 2012).

To better understand students' experiences, we need to listen to their unique perspectives on their own worlds (Oliver, 2010). Various new ways of 'listening' to students' voices have been explored (see O'Sullivan and MacPhail, 2010, 1). For example, Enright and O'Sullivan (2013) used scrapbooking among secondary school girls to access and understand girls' perspectives on popular physical culture and their lives. In a study of students' values, Cothran (2010) reminded teachers to be aware that, in contrast to their teachers, students value non-educational aspects (mostly those connected with fun), such as passing grades, and spending time and playing with friends. She underlined the importance of the meaning of the values students hold, especially when talking about the curriculum (Cothran, 2010). To succeed in any new curriculum, it is important to understand and make connections between students' values and the different courses in sport, dance and fitness that are offered, and by applying different curricular models, such as Sport Education or TGFU (Cothran, 2010). Moreover, the cultural relevance of physical education should not be underestimated. Flory and McCaughtry (2011) argued that care, respect, language and communication, and curricular content, and finding ways of understanding students' voices, are important issues for teachers seeking to enact a cultural relevance cycle in teaching in urban physical education.

However, educators continue to wrestle with the challenge of providing students with relevant physical education programs that do not lead to negative feelings and experiences (Gibbon and Humbert, 2008). Despite such efforts, too many students continue to have feelings of discomfort that can even lead to alienation (Carlson, 1995; Halas, 2002; Spencer-Cavaliere and Rintoul, 2012). In relating alienation to physical education, Carlson (1995) defined three 
constructs: powerlessness (lack of control), meaninglessness (personal value) and social isolation (socially or emotionally isolated from peers). Lack or a low degree of control is related to the student's perception of his/her own skills or the skills of others. Students could be helped to overcome such feelings of powerlessness if they are presented with a range of different activities and the possibility to choose among them (Carlson, 1995; Rees et al., 2006; SpencerCavaliere and Rintoul, 2012; Tischler and McCaughtry, 2011). However, the risk of having too splintered a range of different sports is that the student does not have enough time to learn and absorb everything that is taught. From the standpoint of learning different motor skills, there is simply not enough time available (Bernstein et al., 2011). And when the same content is repeated after an interval, students have often already forgotten what they had previously learned. This does not create a feeling of control (Carlson, 1995; Cothran and Ennis, 1997; Spencer-Cavaliere and Rintoul, 2012) or a positive perception of competence (Stodden et al, 2008), and can hinder participation (Bernstein et al., 2011). The personal value that students attribute to school PE is connected to their perception of the activities in question as repetitious and boring (SpencerCavaliere and Rintoul, 2012). Such perceptions can be changed if the content and delivery of school PE is approached appropriately. Repeating the same things year after year evokes boredom (Carlson, 1995; Spencer-Cavaliere and Rintoul, 2012) which in turn can erode the feeling of fun and enjoyment (Bernstein et al., 2011). How the curriculum is delivered and the atmosphere of the class environment built up depends greatly on the teachers' pedagogic skills (Bailey, 2006; Garn and Cothran, 2006; Halas 2002; Spencer-Cavaliere and Rintoul, 2012). Cooperative learning and student-centered learning methods could be ways of building up a safe environment for learning and enhancing the meaning and personal value of PE (Pagnano, 2006). Negative social experiences and social isolation, including feelings of being left alone and rejected in PE or not being selected for teams, can be reasons for drop-out and disengagement from PE settings (Berg, 2010; Carlson, 1995; Spencer-Cavaliere and Rintoul, 2012; Tischler and McCaughtry, 2011). Too many negative experiences in this area can ruin the possibility for positive experiences and memories of school physical education.

Negative experiences can be major reasons for posting on Internet discussion forums the kinds of messages researched in this study. Discussions and opinions in forums exist independently of research; such forums open the door to an inner world where neither the writers nor the messages are there explicitly for research purposes. This provides an opportunity to follow a conversation in its authentic environment unobserved. People writing in Web forums discuss, express opinions and learn from others (Yun and Park, 2011), and are active in giving and receiving emotional and informational support (Ransom et al., 2010; Pitts, 2004; Seale et al., 2010). Listening to students' voices both for teaching and for research purposes is important but at the same time challenging (Cothran and Kulinna, 2007; Dyson 2006; Fisette, 2013; Subramaniam and Silverman, 2007). To improve teaching and learning, and to 
create a possibility for open interaction between students and teachers, it is important for students to have ways of expressing their thoughts and feelings. For this purpose, the Internet has opened up new possibilities. Writing messages on discussion forums can be seen as a way of expressing disappointment, dislikes and negative experiences that, in the worst cases, can lead to alienation from PE. In turn, expressing enjoyment, likes and positive experiences may strengthen engagement in PE.

In Finland, findings on experiences of PE, which have mainly been studied through questionnaires, have been largely positive, ranging between 68 and 78 \% (e.g. Nupponen et al., 2010; Palomäki and Heikinaro-Johansson, 2011; YliPiipari, 2011). In spite of these results, we found in our earlier studies (Authors et al., 2012, 2013) on school PE in Internet discussion forums that negative messages formed the largest group (64 \%) and positive messages the smallest group $(12 \%)$ of all messages $(n=356)$. In our previous study, the messages posted in the Internet discussion forums described negative experiences of school PE more frequently and more vehemently than previously reported in PE studies. These previous results did not, however, report the content of messages which were both positive and negative. We believe that it would be important more profoundly to analyse the factors underlying these ambivalent messages rather than considering only those that are either wholly positive or negative.

Purpose of the study

Many different methods have been used to explore people's voices in relation to physical education (Dyson, 2006; O'Sullivan and MacPhail, 2010). The aim of the present study was to find out what kinds of PE experiences people describe in Internet discussion forums. More specifically, what factors seem to lead writers of mainly positive messages to include negative thoughts, and vice versa? Gaining knowledge of this issue is important as negative factors could lead the students towards disengagement, whereas positive factors could promote engagement in school PE.

Method

Data Collection

The data for this study were collected from Internet discussion forums during week 15 in April 2012. During the weeks before that date nothing in particular had happened in Finland to prompt any special reason to motivate discussion of PE. The data were collected using a Google ${ }^{\mathrm{TM}}$ search engine with the broad term "koululiikunta" ["school PE" in Finnish] the first 200 hits produced 26 discussion forums. Since no criteria (age, race, class, gender or other) were set, these Web forums represented a variety of areas, including discussions on memories of school sports, health, different hobbies and overweight. These 26 forums were selected, numbered from one to 26 and analysed further. The 
forums contained from 3 to 253 messages varying in length. These discussion forums yielded a total of 1211 separate messages, i.e. every post on each of the 26 sites that were found during this particular week. The data collection protocol was identical to that used in a previous study (Authors et al., 2012).

Data coding

According to Patton (2002: 432) a major challenge for the analytical process in qualitative research lies in the massive amount of data that needs to be sifted to locate the content of interest. The coding of the present data comprised three phases.

Phase 1: Using qualitative content analysis (Patton, 2002: 453), which involves reading and re-reading the messages several times, using inductive analysis (Patton, 2002: 453, 463) four groups of themes were clearly identified. The core consistencies and meanings are identified as patterns or themes, where the pattern refers to a descriptive finding and the theme to a category constructed from the patterns (Patton, 2002: 453). If no negative comments about PE were contained in the message it was categorized as 'Positive', and if the message contained no positive comment it was categorized as 'Negative'. If the message included a single positive comment while the rest was negative or vice versa - it was categorized as 'Both positive and negative', later labelled 'Both'. The fourth group was labelled 'Other'. The messages in this fourth group included, for example, messages about being overweight, smoking, the writer's own physical condition and competitive sport interests, and other school subjects. After reading the messages in the 'Other' group more closely, this group was discarded because it did not directly relate to the topic of present interest (Patton, 2002: 466). This left 1046 messages to be analysed further. To ensure credibility, the data were sequentially coded within three months. Unclear or ambiguous messages were classified together with other members of the research team to guard against too much being read into unclear messages by one individual (Patton, 2002: 466). One forum was taken as a focused test in order to check the consistency of the data coding (Patton, 2002: 466). Two persons from our research team analyzed the same 100 messages independently. The two researchers then compared coding. The result showed 95\% agreement.

This article focuses on the messages in the group "Both", as this was the dominant group, and the main interest was to find out what things, events or matters appear to have been crucial in the overall orientation of the messages. In other words, what factors underlie the feelings and perceptions in these messages?

Phase 2: All the 'Both' messages $(\mathrm{n}=515)$ were recoded into three groups: "Mainly positive", "Mainly negative" and "Mixture of both positive and negative" repeating the process used in Phase 1. The "Mainly positive" messages contained principally positive writings about the subject, with a small 
part or a detail that was negative. For example "I'm in high school, [PE] 3 times a week. The teacher's nice, and the PE classes are fun! Doing gym's a bit boring, but ballgames are fun." $(6,5,5)$. Similarly, the "Mainly negative" messages were chiefly negative but also included a specific positive idea: "School PE took the fun out of sport or years. I still don't want to go skating. Luckily, there were still a couple of sports left that I liked." $(2,7,8)$. The group "Mixture of both positive and negative" included messages with positive and negative statements: "Sure, it's quite... OK. Team games might sometimes get on your nerves, but other times you just love them." $(8,16,61)$.

Phase 3: Since these passages illustrated more than one pattern or theme (Patton, 2002: 463), the messages were further grouped into intrinsic and extrinsic factors, following Carlson's alienation-nonalienation model (1995). In her model, Carlson (1995) classified, first, the intrinsic (student's ability, selfesteem and student's beliefs) and, second, the extrinsic (teacher personality and behaviour, curriculum, class environment, and outside school influences) factors that were known to have an impact on students' feelings towards PE and affect student's meaning-making in school PE (Carlson, 1995). This model, which has already been adapted for PE, also seemed to be suitable in this study for grouping message according to intrinsic and extrinsic factors (Authors et al., 2013). The rest of the model was not applied. In our study, the definitions of both intrinsic and extrinsic factors adapted and enlarged those in Carlson's (1995) original model. According to Patton (2002: 457), the data must not be forced to fit pre-existing categories. Re-reading the messages several times revealed two new intrinsic items: range of emotions, and sidesteps and explanations, and two new extrinsic items: assessment, and facilities and equipment. The ten categories found in this study are shown in Table 1. 
Table 1 The ten categories of intrinsic and extrinsic factors

\begin{tabular}{|c|c|c|}
\hline Factors & Items & Including \\
\hline Intrinsic factors & $\begin{array}{l}\text { Beliefs about PE } \\
\text { Sidesteps and explanations }\end{array}$ & $\begin{array}{l}\text { Thoughts about being good or not good at sport } \\
\text { Being able or not able to perform during PE lessons } \\
\text { Having fears during PE lessons } \\
\text { Liking or disliking PE, } \\
\text { Feelings of embarrassment, } \\
\text { Showering situations } \\
\text { What school PE should or should not be, } \\
\text { The writers' guidelines concerning PE for others } \\
\text { Reasons for absences, } \\
\text { Experiences of peers, } \\
\text { Other factors about sports outside school }\end{array}$ \\
\hline Extrinsic factors & $\begin{array}{l}\text { Class environment } \\
\text { Out-of-school influence and } \\
\text { other factors } \\
\text { Assessment } \\
\text { Facilities and equipment }\end{array}$ & $\begin{array}{l}\text { Liking or disliking the teacher } \\
\text { Liking or disliking his/her behaviour } \\
\text { The possibility for students to choose during lessons } \\
\text { Wide/narrow range of different sports } \\
\text { The number of lessons per week } \\
\text { Different sporting occasions in the school or with other } \\
\text { schools } \\
\text { The size of the class } \\
\text { PE as a compulsory subject } \\
\text { Supportive / depressive feelings } \\
\text { Family and/or coaches } \\
\text { Grades in school reports } \\
\text { Rating and testing } \\
\text { Cross-country skis and skates, balls } \\
\text { Different kinds of gyms and dressing rooms }\end{array}$ \\
\hline
\end{tabular}

The ethics of Internet research

The fact that the Internet plays such a central role in this study means that there are ethical issues to be addressed. In general, the same ethical principles apply in online as in offline research (Moreno et al., 2008). As in offline research, the ethics of online research depend on the nature of the research and on the target group (Basset and O'Riordan, 2002). The topic of this research, school PE, was neither confidential nor private. One basic issue relates to the ethical principles concerning the data collection. All the Internet discussion sites selected were publicly accessible open forums. Discussions and opinions exist in these open forums independently of our research purposes. Therefore no approach towards the forums' operators for permission to undertake the study was considered necessary (Moreno et al., 2008). Informing all the writers of all the discussion forums about the research process would have been totally impossible due to the large numbers of writers, or more precisely, pseudonyms 
involved. The full data (1 211 messages) comprised 663 different pseudonyms in 26 different forums.

One of the most critical ethical issues is to protect participants' anonymity (Ryen, 2007). All the writers behind the messages referred to in this study were given codes in which the first two digits indicate the discussion forum and the third the running number of the message. No claims about the writers' off-line identities can be made (see also Yun and Park, 2011). This study was not interested in identifying the writers behind the messages. Consequently, we cannot say who wrote what message(s) or anything about his or her background (age, gender, ethnicity, etc.). In addition, the time of the writers' experiences of school physical education vary and remain unknown. The original messages were written in Finnish, and hence the quotes from messages given here were translated from Finnish into English for this study by a native English-speaking translator. Within this translation process the original forms of expression, along with possible writing errors, were retained to respect the ethics code of translation in qualitative research (Patton, 2002: 441).

Results

The results of this study reveal how the writers in the Internet discussion forums described their experiences of PE in Finnish schools. Of the 1046 messages, $25 \%$ were positive $(n=259)$ and $26 \%$ were negative $(n=272)$. This article focuses on messages which were both positive and negative at the same time ('Both'), since these surprisingly formed the largest group ( $49 \%, \mathrm{n}=515$ ) and expected to offer a new perspective on the possible factors tending towards engagement in or isolation from school PE. These messages were all grouped into either intrinsic $(32 \%, \mathrm{n}=164)$ or extrinsic $(68 \%, \mathrm{n}=351)$ factors. The results disclose the particular factors that seem to lead writers of 'Mainly positive' messages also to include negative thoughts, and vice versa (Table 2). 


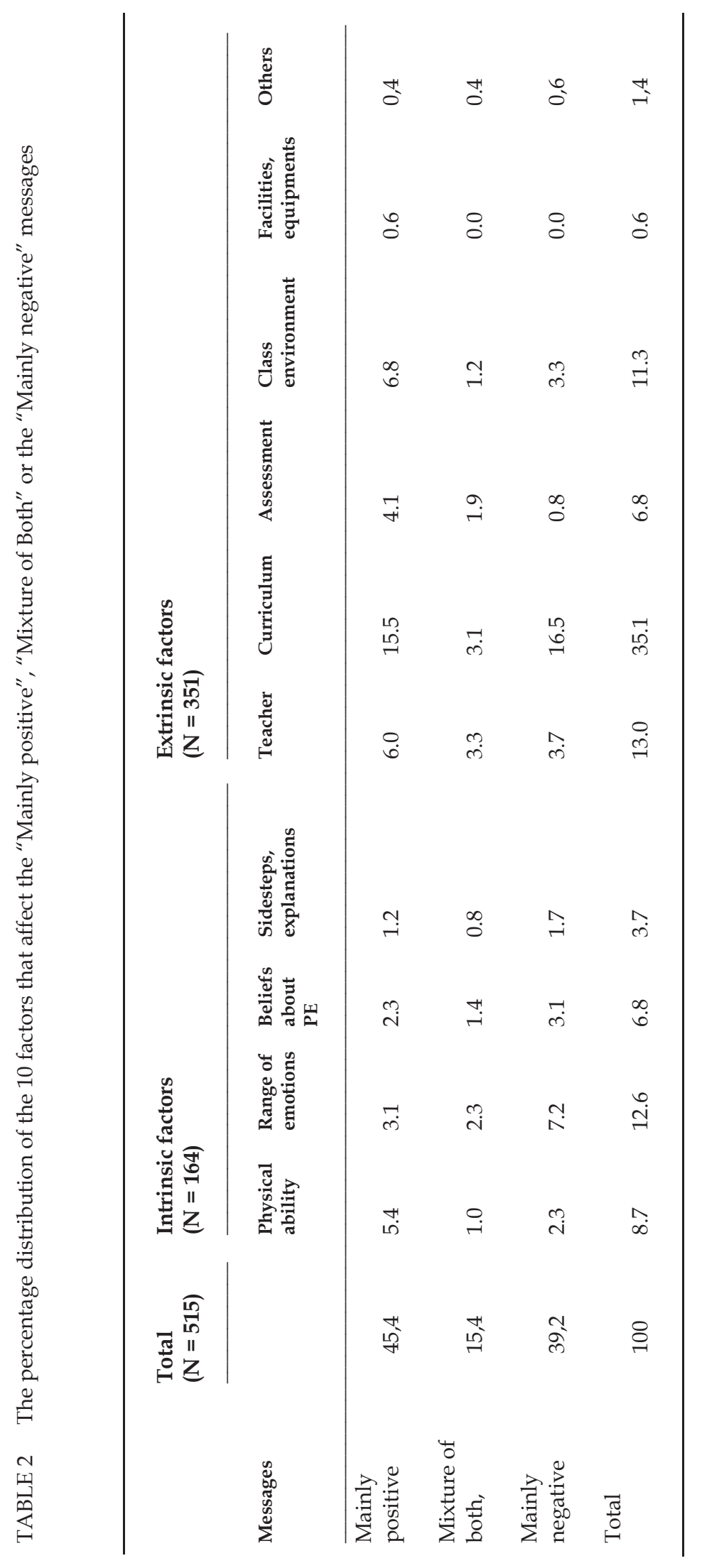


Curriculum

The content analysis clearly revealed that the curriculum plays a crucial role in the writers' messages. Here, curriculum was understood to include the wide or narrow range of different sports, games and other physical activities the school offers as part of physical education (e.g. athletics, orienteering, different ball games, swimming, gymnastics, fitness, dance, and winter sports), the number of PE lessons per week, different sporting occasions in the school or with other schools, the size of the class, and PE as a compulsory school subject. Of the total of "Both" (includes "Mainly positive', 'Mixture of both' and 'Mainly negative') messages ( $n=515)$, more than onethird ( $35 \%)$ mentioned the curriculum as a factor that influenced the writers. In the messages that were 'Mainly positive' the writers nevertheless complained about the narrow range of sports and annual repetition of the same activities (Carlson, 1995; Flintoff and Scraton, 2001; Gibbons and Humbert, 2008). Also, even where the variety of activities was wide, the writers noted some that they did not like. "PE at our school has been relatively varied recently, but naturally there are sports that personally I don't like." $(10,4,22)$ When the writers mentioned school sports or activities they did not like, skiing, swimming and apparatus gymnastics were the most often named. Similar results have been reported in Finland earlier (Palomäki and Heikinaro-Johansson, 2011). The other sports mentioned as disliked were, in order of frequency in the messages, skating, Finnish baseball and floor hockey. In the group 'Mainly negative' the three most often mentioned sports that induced positive feelings were Finnish baseball, swimming and dance. "I'm anyway bad at PE, the only things I like are swimming and Finnish baseball and we don't get to do them often." (7,14,92) (Hill and Cleven, 2005; Palomäki and Heikinaro-Johansson, 2011). After these, in rank order, were training in the gym, football and orienteering. What writers wanted more of were jogging and gymnastics. "There should be more gymnastics, running etc., other types of training in PE." $(3,13,133)$ (see also Gibbons and Humbert, 2008; Spencer-Cavaliere and Rintoul, 2012). In the group 'Mainly negative', some writers had ideas for redesigning school PE as a whole by removing $\mathrm{PE}$ as such and replacing it with a couple of hours of compulsory walking.

"But why can't PE classes be held by 3-4- teachers at the same time? One could offer Finnish baseball, another dance, a third orienteering, a fourth floorball. It would at least be possible to choose the one you hate least." $(1,14,22)$.

Next to different sports, some writers mentioned group sizes: “... Big groups especially in team sports were the fucking pits when you had to stand around on the edge of the field waiting." $(3,7,16)$. Also the number of hours of PE was something that some writers wanted increased: "I'm in the ninth grade in comprehensive school, [PE] once a week, two hours (pity). I think PE's great! The teacher's great! If only there were more hours!" $(6,5,6)$. In some messages two-hour periods were seen to be tough: " $2 \mathrm{~h}$ wouldn't be bad if there was something a bit lighter in between apart from football and baseball." $(1,13,89)$. Having PE first thing in the morning or just in the middle of the day was disliked: " The only negative side to school PE is that it really sucks if the classes are in the middle of the day or at the beginning of the day." $(1,13,147)$. The reasons mentioned for this were still being too tired or that the 15-min break is too short to have a shower and get dressed again. In the 'Mainly 
positive' messages, PE lessons during primary school (7-12 years) were unpleasant according some writers: "In secondary school we had two hours [PE] on a Tuesday (that is, once a week), it was fine, then. In primary school it was pure hell." $(6,5,8)$. And in the 'Mainly negative' messages just the opposite, "Annoying to think how school PE changed when we moved from primary school. Then, always nice and there were no disagreeable activities and the teacher didn't expect you to be perfect at everything". $(10,5,99)$. High school PE showed divided opinions within writers even in the same group, but in both groups PE in high school was mentioned favorably, mostly because of the possibility to choose their PE courses:

"The main problem with school PE is that you have to do exactly what is set. I'm talking about PE in comprehensive school. There could have been a bit more choice. Often, I would rather have gone for a walk or a run instead of having to play set games. Fortunately, in high school you usually have more choice..." $(3,13,190)$.

The curriculum was clearly the commonest factor among the 'Mainly positive', 'Mixture of both' and 'Mainly negative' messages. In order of frequency, after the curriculum, with roughly equal frequencies, were two extrinsic factors, the teacher and the class environment, and one intrinsic factor, range of emotions.

Teacher

The teacher and his/her behaviour in $13 \%$ of the messages, was the next factor mentioned. Teachers' personalities were described broadly, especially their characteristics, age and appearance. In the 'Mainly positive' messages, the teacher was often described negatively as "I'd like more [PE], although the teacher's an asshole" $(6,5,26)$ or

"There are good teachers and there are so called bad ones. There are certainly nasty PE teachers, no doubt about that. You find the same evil-mindedness among all subject teachers. It's a pity that you always come up against someone like that at some point. Luckily, there are good ones as well." $(2,11,52)$.

Teachers' behaviour in the 'Mainly positive' messages was also mentioned negatively. According to one writer, "It'd be terrific if everyone could have such a supportive teacher, which of course is never going to happen" (10,5,48). Another writer, although liking PE and the teacher in general, complained that sometimes teachers have 'ridiculous expectations' of their students. "It's hard and unrealistic to imagine that PE teachers should all be competent, have a psychological eye for the internal dynamics of groups and be able to support fair play." $(3,13,186)$.

Many different positive words were used to describe the personality of teachers in the 'Mainly negative' messages. Many writers wrote different adjectives about the teacher: "Teach is nice and young and supports everyone, but school PE sucks" $(6,5,24)$ or " Our previous PE teacher retired in the autumn and then we got a really pleasant and good substitute who didn't keep on testing us and I, who've ALWAYS hated school PE, really started to like going to class and I was often like "yeah, PE" $(10,5,87)$. One writer had specially warm feelings towards the teacher after all: 
"I have the kind of experiences of PE teachers that you can only describe as tormenting the student. Once a PE teacher in front of the whole class compared my performance to that of a physically handicapped person. And said it was even worse. I don't want to say any more about that here now. Well, this teacher-tormentor scared me by saying that when I moved to the next school I wouldn't be able to cope if I didn't agree to having remedial tuition in PE from her. In the next school the PE teacher was the complete opposite. She was an angel....that woman had her heart in the right place." $(2,11,70)$.

The importance of the teacher has also been reported in earlier studies (Bailey, 2006; Carlson, 1995; Cothran and Ennis, 1999; Flintoff and Scraton, 2001; Rikard and Banville, 2006; Spencer-Cavaliere and Rintoul, 2012; Strean, 2009), also in Finnish context (Klemola et al., 2013).

Class environment

Class environment was mentioned particularly often in the 'Mainly positive' messages, and thus may be an important factor affecting writers. Many writers were frustrated by and disappointed with their classmates' behaviour during PE lessons. Other students not trying to do the given task, or just hanging around and chatting with each other while the others wanted to play or concentrate on the activity, was a cause of complaint.

"Have you ever heard of trying? You don't have to be the best or good at something but it really pisses you off when people don't lift a finger. In my opinion PE lessons are there so you can practice different sports activities a few times a year so you'd imagine that it wouldn't hurt just to try and not just stand around with your hands in your pockets on the field or wherever you happen to be." $(3,7,32)$

The atmosphere in the class in general, students teasing or humiliating other students, was also noticeable in the messages (Carlson, 1995; Cothran and Ennis, 1999; Spencer-Cavaliere and Rintoul, 2012). It usually happened in situations where two classes were combined for PE or it was boys teasing girls, though in Finland most school PE lessons boys and girls are taught separately. The moments when students were divided into teams or groups were also reported as negative moments. Those left to last suffered from feelings of humiliation and shame (Carlson, 1995; Cothran and Ennis, 1999). In the 'Mainly negative' messages some writers nevertheless were slightly positive about their classes:

"I've been lucky in that the PE groups I was in were nearly always quite OK. But I still have bitter memories of team games when the best students rolled their eyes and sighed in mock agony because I wasn't as good as the others or I was the last one left when teams were being picked." $(10,5,66)$

Similar findings have been reported in previous research (Spencer-Cavaliere and Rintoul, 2012).

\section{Range of emotions}

The second factor mentioned in the 'Mainly negative' messages was emotions. These ranged from extreme liking to extreme disliking for physical education or sports in general. Many writers in both the 'Mainly positive' and 'Mainly negative' groups 
stated that he/she liked or even loved sports and physical activity, but only outside school. Physical education in the school was something these writers disliked intensely. One writer expressed his/her opinion very clearly: "I have a bottomless hatred of school PE. I stress the word SCHOOL, as I don't have anything against physical exercise as such." $(10,5,83)$. In most of the messages no explanation was given for this 'hate'. In some messages, however, the writers gave reasons for their strong negative feelings: for example teachers, tests, evaluations, swimming, skiing, and sporty team games were mentioned. Some writers stated that they only started to feel the joy of sport after leaving school. Lack of student autonomy coupled with a strongly authoritarian teacher was another reason: "All that laddish bluster or dreadful bossiness, it really didn't make you want to do anything...The pleasure of physical activity only really came after I left school." $(4,6,9)$. These results also support earlier findings (Berg, 2010; Dismore and Bailey, 2010; Tischler and McCaughtry, 2011).

\section{Discussion and conclusion}

Our aim was to identify what factors influence writers in Internet forums to include negative thoughts in 'Mainly positive' messages, and vice versa. The results showed clearly that the curriculum was the main factor that affected writers' feelings and opinions (see also Dismore and Bailey, 2010). Hence widening the range of sports would help students to find something on the curriculum that they can enjoy (Cothran, 2010; Rikard and Banville, 2010; Tischler and McCaughtry, 2011) both at school and in the future (Gibbons and Humbert, 2008). After the curriculum, in order of frequency, were the teacher, the class environment, and emotions. Many earlier studies have reported results similar to ours on the role of the teacher in the educational setting (e.g. Cothran, 2010; Rikard and Banville, 2006; Strean, 2009). Also, research on the class environment has reported many similarities with the present findings (e.g. Ferry et al., 2011; Strean, 2009). The emotions that emerged in this study highlight a serious issue: regardless of whether their opinions are positive or negative, many writers claimed to love physical activity while hating school PE (Tischler and McCaughtry, 2011).

Our interest was directed towards messages that included both positive and negative expressions, as these were the ones that challenge not only teachers but also the curriculum to find ways of implementing PE so as to promote positive rather than negative attitudes to the subject. This was also surprisingly the dominant group in this new data gathered in 2012, as it comprised $49 \%$ of all the messages $(n=1211)$. Reading through the wholly positive and wholly negative messages in this data, no new factors appeared (cf Authors et al., 2013). If solely positive and/or negative messages are reported, we lose those with feelings and opinions in the 'grey area', which was a phenomenon that attracted our interest. Grouping these ambivalent messages according to our enlarged Carlson's model (1995) showed that the intrinsic factors of physical ability, beliefs about PE, and sidesteps and explanations, and the extrinsic issues of assessment, facilities and equipment, and others were clearly less important factors underlying these messages. 
The present results can be seen either as positive in relation to engagement in school PE, or negative in that they demonstrate possible factors leading towards alienation from school physical education. Among the positive factors contained in the 'Mainly negative' opinions, curriculum-related issues came first. The activities that these writers most often mentioned as ones they liked were Finnish baseball, swimming and dance. These results support the findings of a follow-up evaluation of PE learning outcomes in Finland in spring 2010 (Palomäki and HeikinaroJohansson, 2011). Offering a wide range of different sports, games and other physical activities may be one way of retaining student interest in physical education. The same sports are not for everyone, which makes it important, therefore, that the student has a meaningful choice. Carlson (1995) emphasizes the importance of choice as a factor affecting the degree of control students have over what happens in PE (see also Hagger et al., 2009; Spencer-Cavaliere and Rintoul, 2012).

When reforming the curriculum with the aim of developing students' fundamental movement skills rather than teaching specific sports, it should be remembered that for some students it is precisely specific sports that can lead towards engagement in PE. This was confirmed by our findings: for example, one writer reported being bad at PE and that "...the only things I like are swimming and Finnish baseball..." $(7,14,92)$. Feelings of self-confidence arise after a purposeful amount of repetition, while motivation increases when something new is learned. Another important factor is the teacher. As we found here, a supportive, not overly demanding person with a "heart" can do much to maintain student interest in PE. This, however, requires a lot from the teacher.

To understand the social, mental and physical development of a child both in theory and in practice - one writer wanted the teacher to have "...a psychological eye..." $(3,13,186)$ - means teaching experience over a longer period. It also requires that PETE programs move away from sub-disciplinary coursework based on exercise physiology, biomechanics, anatomy and physiology, and toward courses in educational psychology and sociology. Despite the emphasis on education in the Finnish PETE context, teachers' continue to be criticized for not giving students a greater measure of autonomy or using student-centered teaching methods and listening to students' voices, a point frequently made in these messages. Recently graduated young teachers full of energy and self-confidence have the obvious advantage of being "nice and young"; but to be able to take a broader view of the growing child or adolescent, the teacher also needs a certain level of maturity. The teacher has to know 'who' their specific students are as individuals, groups, and as a whole, and accept them for who they are (Ferry et al., 2011). Being able to teach skills in a supportive way in a nonjudgmental class atmosphere is challenging, but possible (Spencer-Cavaliere and Rintoul, 2012). It requires courage on the part of the teacher to ensure that all students have equal opportunities (Azzarito et al., 2006) and to protect individual students as they are (Tischler and McCaughtry, 2011).

Most of the research and effort that has gone into physical education pedagogy has tended to focus on how to better present, frame and facilitate the content of PE rather than the content itself. Our findings clearly show how important individual physical activities are for how students' experience of school PE. Something must be wrong in our physical education setting if people writing in Internet discussion 
forums say that they like or even love physical activities and sports in general, but dislike or "hate" school PE. The results of this study found that the main factor causing students to have negative rather than positive feelings is the curriculum, and specially the range of different sports, games and other physical activities on offer. The three activities most often described as giving rise to feelings of discomfort were [cross-country] skiing, swimming and apparatus gymnastics (see also Palomäki and Heikinaro-Johansson, 2011). Such sports may require personal equipment that has to be carried to school, the weather can be crucial in outdoor activities, and students may feel ashamed of their bodies, may feel cold in the swimming pool or on the track, or may have a real fear of failing due a lack of skills. Having to rush from one place to another and not having sufficient time to get showered and dressed ( Rees et al., 2006) and put on makeup, especially after swimming lessons, could also partly explain these negative feelings, particularly of female students. The social pressure to look good is strong (Enright and O'Sullivan, 2013). Despite all this, it is noteworthy that swimming was also among the top three most liked school PE activities. If these PE contents were more closely related to students' lives (Flintoff and Scraton, 2001) and had a future meaning and value (Carlson, 1995; Cothran, 2010) for them, they might be experienced more positively.

In the Finnish culture, for example, swimming skills are needed because of the thousands of lakes and outdoor water-related activities in the country. Teaching methods also have an important influence on how students experience the subject (Tischler and McCaughtry, 2011). A challenge for teacher education is to be able to identify the skills and methods that future teachers will need to create a safe learning environment. Whether the candidates best able to realize this objective in the future are best selected through entrance examinations (as in Finland) is also a matter for further debate. Disliking and withdrawing from PE may be an outcome if the student is not able to feel safe and surrounded by a caring social and emotional environment (Carlson, 1995), including both teacher and peers (Ferry et al., 2011; Klemola et al., 2013). The importance of the quality of the interaction between teacher and student and between students cannot be too strongly emphasized.

\section{Limitations}

This study has limitations that should be acknowledged. First, the writers, and hence precisely when they experienced the feelings they write about, are unknown. Since there were many $(n=663)$ different pseudonyms posting all these messages $(n=$ 1211), we assume that they reflect the situation of more than just a few persons. In some studies, such topics have been investigated by setting up a specific forum for research purposes. This was not the case in this study. Discussions and opinions exist in forums independently of research purposes. Data collected in this way are totally unaffected by social pressure (Yun and Park, 2011) or the need to please interviewers or teachers (cf. Seale et al., 2010). For this reason, all the facts about the writers and their background remain unknown. It may be that the Internet encourages more forthright expression (Yun and Park, 2011) and that negative examples fuel competition between writers. To obtain the most inclusive view of these phenomena different data collection methods should be used in combination. 
We had decided earlier in this project to utilize Carlson's (1995) model adapted for PE in the analytical process in Phase 3. She classified the factors that were known to have an impact on students' feelings towards PE into two groups: intrinsic and extrinsic (Carlson, 1995). This distinction was not always unambiguous, since, for example, a particular physical activity (extrinsic factor) can be something a student holds motivation (intrinsic factor) for participating in. An intertwined ecology, with student personal, teacher/curricular, social/environmental, informing and being informed by one another, might have worked at least as well in this study

\section{Practical implications and Conclusions}

The findings of this study call for everyone working together with physical education to listen to the voices of students (MacPhail, 2011). We encourage teachers and teacher educators to now and again check and read what is written in Internet discussion forums. In the future, every opinion that gives a sign of possible withdrawal from a physically active lifestyle should be taken seriously. Decisions on PE curriculum reform in schools and the contents of teacher education should reflect the needs and values of today's students. The implications of these decisions for a physically active lifestyle - to support or discourage it - remain to be seen.

Messages in the Internet discussion forums that at the same time include both positive and negative opinions present teachers, teacher education and the curriculum with the challenge of changing negative opinions into positive ones. At the same time they give us the task of strengthening positive outcomes by offering experiences that at least somehow connect school physical education with students' lives.

\section{References}

Annerstedt C (2008) Physical education in Scandinavia with a focus on Sweden: acomparative perspective. Physical Education \& Sport Pedagogy 13(4): 303-318.

Authors et al (2012)

Authors et al (2013)

Azzarito L, Solmon MA and Harrison L (2006) “...If I had a choice, I would..." A feminist poststructuralist perspective on girls in physical education. Research Quarterly for Exercise and Sport 77(2): 222-239.

Bailey R (2006) Physical Education and Sport in Schools: A review of benefits and outcomes. Journal of School Health 76(8): 397-401.

Bassett EH and O'Riordan K (2002) Ethics of Internet research: contesting the human subjects research model. Ethics and Information Technology 4(3): 233-247.

Berg P (2010) Group boundaries and hierarchies: Ethnographic study of physical education in secondary school. PhD Thesis, University of Helsinki, Finland.

Bernstein E, Phillips SR and Silverman S (2011) Attitudes and perceptions of middle school students toward competitive activities in physical education. Journal of Teaching in Physical Education 30(1): 69-83. 
Bevans K, Fitzpatrick L-A, Sanchez B, et al. (2010) Individual and instructional determinants of student engagement in physical education. Journal of Teaching in Physical Education 29(4): 399-416.

Carlson T (1995) We hate gym: Student alienation from physical education. Journal of Teaching in Physical Education 14(4): 467-477.

Cothran D (2010) Students' curricular values and experiences. In: O'Sullivan M and MacPhail A (eds) Young People's Voices in Physical Education and Youth Sport. London: Routledge, pp.49-62.

Cothran DJ and Ennis CD (1997) Students' and teachers' perceptions of conflict and power. Teaching and Teacher Education 13(5): 541-553.

Cothran DJ and Ennis CD (1999) Alone in a crowd: meeting students' needs for relevance and connection in urban high school physical education. Journal of Teaching in Physical Education 18(2): 234-247.

Cothran DJ and Kulinna PH (2007) Students' reports of misbehavior in physical education. Research Quarterly for Exercise and Sport 78(3): 216-224.

Dismore H and Bailey R (2010) 'It has been a bit of a rocky start': attitudes towards physical education following transition. Physical Education \& Sport Pedagogy 15(2): 175-191.

Dyson B (2006) Students' perspectives of physical education. In: Kirk D, Macdonald D and O'Sullivan M (eds) The Handbook of Physical Education. London: Sage Publications, pp.326-346.

Enright E and O'Sullivan M (2013) Now, I'm magazine detective the whole time": listening and responding to young people's complex experiences of popular physical culture. Journal of Teaching in Physical Education 32(4): 394-418.

Ferry M, McCaughtry N and Hodges Kulinna P (2011) Social and emotional pedagogy: rhythm and junctures. Journal of Teaching in Physical Education 30(1): 13-30.

Finnish National Core Curriculum for Basic Education (2004) Available at: http://www.oph.fi/english (accessed 27 January 2014).

Fisette JL (2013) 'Are you listening?': adolescent girls voice how they negotiate selfidentified barriers to their success and survival in physical education. Physical Education and Sport Pedagogy 18(2): 184-203.

Flintoff A and Scranton S (2001) Stepping into active leisure? Young women's perceptions of active lifestyles and their experiences of school physical education. Sport, Education and Society 6(1): 5-21.

Flory SB and McCaughtry N (2011) Culturally relevant physical education in urban schools: reflecting cultural knowledge. Research Quarterly for Exercise and Sport 82(1): 49-60.

Garn AD and Cothran DJ (2006) The fun factor in physical education. Journal of Teaching in Physical Education 25(3): 281-297.

Gibbons SL and Humber L (2008) What are middle-school girls looking for in physical education? Canadian Journal of Education 31(1): 167-186.

Hagger M, Chatzisarantis N, Hein V, et al. (2009) Teacher, peer, and parent autonomy support in physical education and leisure-time physical activity: A trans contextual model of motivation in four nations. Psychology and Health 24(6): 689-711. 
Halas J (2002) Engaging alienated youth in physical education: an alternative program with lessons for the traditional class. Journal of Teaching in Physical Education 21(3): 267-286.

Hill G and Cleven B (2005) A comparison of 9th grade male and female physical education activities preferences and support for coeducational groupings. Physical Educator 62(4): 187-198.

Klemola U, Heikinaro-Johansson P and O'Sullivan M (2013) Physical education student teachers' perceptions of applying knowledge and skills about emotional understanding studied in PETE in a one-year teaching practicum. Physical Education and Sport Pedagogy 1(18): 28-41.

MacPhail A (2011) Youth voices in physical education and sport: what are they telling us?, In: Armour K (ed) Sport Pedagogy: An Introduction for Teaching and Coaching. Harrow: Prentice Hall, pp.105-116.

Mann SJ (2001) Alternative perspectives on the student experience: alienation and engagement. Studies in Higher Education 26(1): 7-19.

Moreno MA, Frost NC and Christakis DA (2008) Research ethics in the MySpace era. Pediatrics 121(1): 157-161.

National Association for Sport and Physical Education (2001) Physical education is critical to a complete education [Position statement]. Reston, VA: Author.

National Association for Sport and Physical Education (2004) Moving into the Future: national standards for physical education. Reston: NASPE Publications.

Nupponen H, Penttinen S, Pehkonen M, et al. (2010) Koululiikunnan vaikuttavuustutkimus: Lähtökohdat, menetelmät ja aineiston kuvaus. Turku: Digipaino.

Oliver KL (2010) The body, physical activity and inequity. In: O'Sullivan M and MacPhail A (eds) Young People's Voices in Physical Education and YouthSport. London: Routledge, pp.31-48.

O'Sullivan M and MacPhail A (2010) Young People's Voices in Physical Education and Youth Sport. London: Routledge.

Pagnano KB (2006) Find meaning in middle school physical education. Teaching Elementary Physical Education 17(4): 12-15.

Palomäki S and Heikinaro-Johansson P (2011) Liikunnan seuranta-arviointi perusopetuksessa 2010. [A follow up evaluation of physical education learning outcomes]. Koulutuksen seurantaraportti 2011: 4. Helsinki: Opetushallitus.

Patton M (2002) Qualitative research \& evaluation methods. Thousand Oaks, CA: Sage.

Pitts V (2004) Illness and Internet empowerment: writing and reading breast cancer in cyberspace. Health 8(1): 33-59.

Ransom DC, La Guardia JG, Woody EZ, et al. (2010) Interpersonal interactions on online forums addressing eating concerns. International Journal of Eating Disorders 43(2): 161-170.

Rees R, Kavanagh J, Harden A, et al. (2006) Young people and physical activity: a systematic review matching their views to effective interventions. Health Education Research 21(6): 806-825.

Rikard GL and Banville D (2006) High school student attitudes about physical education. Sport, Education and Society 11(4): 385-400.

Ryen A (2007) Ethical issues. In Seale C, Gobo G, Gubrium FJ and Silverman D (eds), Qualitative Research Practice. London: Sage, pp.218-235. 
Seale C, Charteris-Black J, MacFarlane A, et al. (2010) Interviews and Internet forums: a comparison of two sources of qualitative data. Qualitative Health Research 20(5): 595-606.

Spencer-Cavaliere N and Rintoul MA (2012) Alienation in physical education from the perspective of children. Journal of Teaching in Physical Education 31(4): 344-361.

Stodden DF, Goodway JD, Langendorfer SJ, et al. (2008) A developmental perspective on the role of motor skill competence in physical activity: an emergent relationship. Quest 60(2): 290-306.

Strean WB (2009) Remembering instructors: play, pain and pedagogy. Qualitative Research in Sport and Exercise 1(3): 210-220.

Subramaniam PR and Silverman S (2007) Middle school students' attitudes towards physical education. Teaching and Teacher Education 23(5): 602-611.

Tischler A and McCaughtry N (2011) PE is not for me: when boys' masculinities are threatened. Research Quarterly for Exercise and Sport 82(1): 37-48.

Welk GJ (1999) The youth physical activity promotion model: A conceptual bridge between theory and practice. Quest 51(1): 5-23.

Yli-Piipari S (2011) The development of students' physical education motivation and physical activity: A 3.5-year longitudinal study across grades 6 to 9. PhD Thesis, University of Jyväskylä, Finland.

Yun GW and Park S-Y (2011) Selective posting: Willingness to post a message online. Journal of Computer-Mediated Communication 16(2): 201-227. 